\title{
Clinical and Experimental Studies on Thyroid Stimulating Hormone
}

I. Bioassay for Thyroid Stimulating Hormone (TSH) Based upon Inorganic Radioiodine Uptake and Release of Surviving Bovine Thyroid Slices

By

\section{Itaru NAGATA}

First Division, Department of Internal Medicine, Medical Faculty, Kyoto University

(Director : Professor G. Wakisaka, M.D.)

A new technique for the quantitative determination of $\mathrm{TSH}$, based on the measurement of the hormone in stimulating thyroidal uptake and release of inorganic radioiodine, was further investigated using surviving bovine thyroid slices in vitro. The results were as follows :

1) TSH, added in vitro, stimulated the uptake and decreased the release of inorganic iodine by the slices.

2) According to the results of the chromatographic separation, the radioactivity discharged into the medium after the release experiment was not of hormonal radioiodine but of inorganic.

3) In the uptake experiment, when TSH and radioiodine were added simultaneously, no usefull TSH dose-response proportionality was obtained. There were statistically significant differences in the radioiodine uptake among $10^{-4}, 10^{-3}, 10^{-2}$ and $10^{-1} \mathrm{JSu} / \mathrm{ml}$ of $\mathrm{TSH}$ when the thyroid slices were incubated with TSH for 4 hours prior to the addition of radioiodine. However the reproductivity of these relationships was very poor.

4) In the release experiment, statistically significant linearity and differences were observed over the range from $10^{-5}$ to $10^{-2} \mathrm{JSu} / \mathrm{ml}$ of $\mathrm{TSH}$, but there was a great variation in the TSH dose-response curve and the mean $\lambda$ value was 0.68 , being higher than that obtained by any other recent techniques.

5) For the purpose to increase the slope of the dose-response curve and augment the precision in the release experiment developed by Bakke et al., the author has made some improvements on their method, and obtained satisfactory outcomes for the most part. This procedure seems to offer a fairly convenient and sensitive technique for the assay of TSH; with a mean $\lambda$ of 0.34 , as precise as that obtained by current methods.

6) 1 USP unit was estimated to be equivallent approximately to $10 \mathrm{JS}$ units by the improved release experiment applied to the 4 or 6 point method. 


\title{
Clinical and Experimental Studies on Thyroid Stimulating Hormone
}

\author{
II. Assay of Thyrotrophin in Human Serum under \\ Normal and Endocrinopathic Conditions
}

By

\section{Itaru NAGATA}

(First Division, Department of Internal Medicine, Faculty of Medicine, Kyoto University)

(Director : Professor G. Wakisaka, M.D.)

A modified assay technique for thyrothrophin (TSH) based on the release of inorganic radioiodine by bovine thyroid tissue slices in vitro was designed for its clinical application and was used in titrations of serum TSH levels in various disorders.

In normal adults, the mean serum TSH level was $1.82 \pm 1.38$ (standard deviation) milli JSU $/ \mathrm{ml}$ in 15 males in the 2 nd $\sim 4$ th decades, $0.89 \pm 0.54 \mathrm{milli} \mathrm{JSU} / \mathrm{ml}$ in 5 males above the 5 th decade, and $1.91 \pm 1.49 \mathrm{milli} \mathrm{JSU} / \mathrm{ml}$ in 21 femeles in the $2 \mathrm{nd}$ and $3 \mathrm{rd}$ decades. The confidence limit $(\mathrm{P}=0.05)$ of sernm TSH level in 41 normal adults was $2.2 \sim 1.3 \mathrm{milli} \mathrm{JSU} / \mathrm{ml}$, and its seasonal changes was estimated.

In simple goiters, the serum TSH level in PAS induced- and endemic diffuse goiter was rather high, but in cystic or nodular type it was normal or partially low. In these euthyroid patients, a negative correlation between the TSH level and the PBI value in serum was observed.

In primary hypothyroidism, the serum TSH level was markedly elevated. On the contrary, in secondary hypothyroidism it was extraordinarily decreased or beyond measure.

In hyperthyroid patients, the serum TSH level varied from less than 0.1 to more than 10 milli $\mathrm{JSU} / \mathrm{ml}$, its mean value was in upper part of the normal range, 'and abnormally high or low levels of TSH in serum were observed not only in the group with exophthalmos but also in the group without exophthalmos, whereas the former showed somewhat high level of TSH in serum on the average. Two euthyroid patients without goiter but with marked exophthalmos did not differ from normals in their serum TSH levels. In the group of hyperthyroidism, in which the thyroidal radioiodine uptake curve showed the "descending type", exophthalmos was more frequenthy observed and the serum TSH level tended to be higher than that of the group showing the "ascending type" of the thyroidal radioiodine uptake curve. The serum TSH level in hyperthyroidism was more correlated with the 6-hour thyroidal radioiodine uptake rate than with the serum PBI value but the level of significance was low in both cases.

The change of TSH level in serum after the administration of $100 \sim 150$ JS unit of Pretiron was estimated in some thyroid disorders.

The amount of TSH in several hypophyseal, adrenal and other endocrine-, and other diseases was more or less decreased. In a group of peptic ulcer and intestinal dyskinesia, a correlation between the serum TSH level and the free 17-OHCS excreted in urine was observed to some extent.

The effect of thyroid hormone, vasopressin, ACTH, adrenocortical steroid and some goitrogens on the TSH activity in serum was also investigated in some clinical cases.

Clinical significance of the obtained results are discussed. 


\section{甲状腺刺战ホルモン（TSH）に関する臨床的}

\section{並びに㬰験的研究}

第 1 報 牛甲状腺薄片の $\mathrm{I}^{131}$ 摂取並びに放出による TSH 測定法

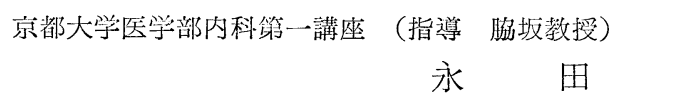

格

緒言

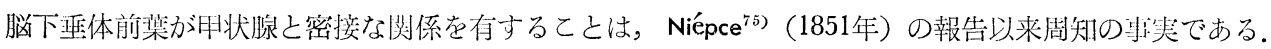
脳下西体前葉に甲状腺賦活物質の存在することが Smith et $\mathrm{al}^{87}$. (1922年)によりはじりて見出され，甲状 腺刺戟ホルモン (TSH) として Loeb et $\mathrm{al}^{73}$. (1929年) によつて浱縮分離されてから斯界に於ける呼究の 進歩"979 791888)には見るべきあのがあるが，その詳細に就いては未だ不明な点が多い，近年に至つて更に上 位の中枢として視床下部が5758)，下垂体ひいては甲状腺に対して演ずる役割に就いても種々論ぜられるよう そなつた。

target gland としての甲状腺の機能に及ぼす TSH の影響或は各種甲状腺聅患に於ける病態生理を解明 するに際しては，相互に関連するてれら上位諸中怄の意義を明らかにする必要のあることは云う迄すなく。 その手段の一つとして体液中に於ける TSH の動態を知ることは極少て重要であると考えられる。

TSH の測定法に関しては，Junkmann \& Schoeller ${ }^{64)}$ (1932年) がその単位を制定して以来多数の報告があ り。本邦に於いてあ既亿幾つかの綜説 ${ }^{1{ }^{10}}{ }^{10}$ 亿紹介されているが，臨床に応用されたのはその一部のみで， 未だ一般に承認されるには至らず，更感度の高い正確且つ簡便なる方法の望まれているのか涀沅である.

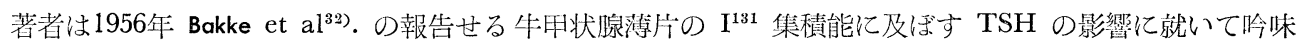
すると共に，ての機序を応用するととにより，血中の微量 TSH 測定を可能ならしめる心゙く実験的検討を垂 ねた。茲にその成績の大要を報告する。

\section{実験材料並びに方法}

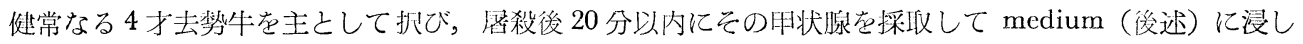
て, 約 $4^{\circ} \mathrm{C}$ 亿保持しながら研究空に持ち帚り, 被膜・結合織・脂肪組織等在可及的分滩して後直ちに組織の 辺縁を避けた中央部の均一な部分より西洋剃刀を用いて free hand で愿さ約 $0.5 \mathrm{~mm}$ のslice を作製した。 slice は，附着せる血液その他を除去するために繰返して洗涤し， hydration による組織重量の増加を考虑 して約 20 分間 $4^{\circ} \mathrm{C}$ 亿冷却せる medium 中に放䈯してから手早く torsion balance で秤量して重量 $100 \mathrm{mg}$ 均 一の slice そした.

medium には Krebs-Ringer 氏液を stock solution 㘦らの都度調製し， phosphate buffer により pH 7.4 として使用した。後述の検討の結果，medium には carrier として沃度の終末濃度が $10 \mu \mathrm{g} / \mathrm{dl}$ になる 如く沃度加里を添加し，又沃度の有機合成を阻止するたもに mercazole (1-methyl-2-mercaptoimidazole 中 外製薬製) を終末濐度が $1 \mathrm{mg} / \mathrm{dl}$ となる如く含有せしめた。

radioisotope tracer としては $\mathrm{NaI}^{131}$ (carrier free) を使用し，組織への影響年をを考虑して濃度 $0.1 \mu \mathrm{c} / \mathrm{ml}$ 以下で用いた。

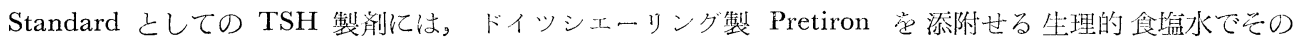
都度溶解して承室に谏結保存し, 少なくとも 4 日以内に使用した。 その 1 Ms単位は 1 Junkmann-Schoeller 第35巻 第11号 
単位 (JSu) に相当するので，以下すべて JSu で表すとととする。

Shaking incubation には26ケの容器を同時に振䀊出来る如く改装した Warburg 検圧計を用い, incubate の温度は $38^{\circ} \mathrm{C}$ ，振渴周期は毎分60回を通常とした。容器内ガス腔は，はじめ酸素 $95 \%$ ，炭酸ガス $5 \%$ の混合 ガスで置換したが、その必要なきととを確めてのちガス交換を省略した。

放射能測定には通常島津製 well type. scintillation counter (Crystal Na I $1^{3} / 4^{\prime \prime} \times 2^{\prime \prime} \phi$, DI 型 super scaler）を使用しそその性能及び資料の計測率（每分計測数）上り，標準計測誤差が常に $1 \%$ 以下に止る如 く測定時間（通常 2 分）を定めた。

Experimental

(A) Materials

fresh bovine thyroid slice : $100 \mathrm{mg}$ weight,

$0.5 \mathrm{~mm}$ thick. Krebs-Ringer phosphate :

pH7.4, Mercazole, KI.

(B) Methods

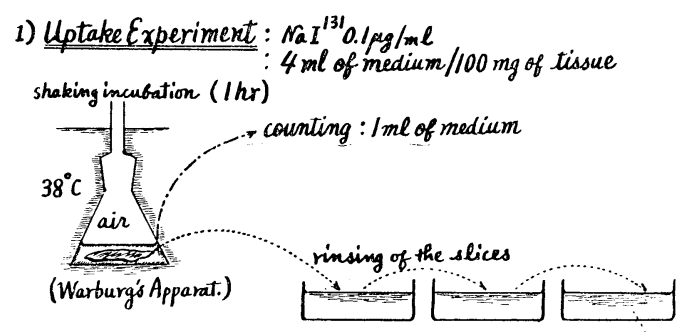

2) Release Experiment: $3 \mathrm{ml}$ of medium/100 mg of tissue

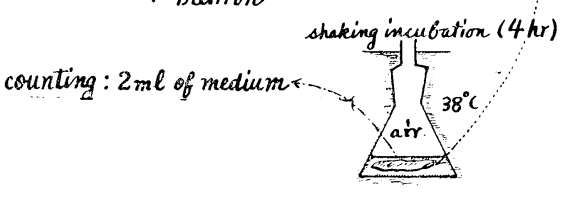

実験は， I ${ }^{131}$ 在含有する medium 中で slice を incubate して medium 中の $\mathrm{I}^{131}$ を 掑取せしめる摂取実験と， $I^{131}$ を摂取せる slice を更に incubate して I ${ }^{131}$ を含まぬ medium 中に放出させる放出実験とに分つ.

\section{1) 攝取実験}

slice 重量に対する $I^{131}$ 含有 medium の容 量を常に一定の比率（通常 $100 \mathrm{mg}$ に付き 4 $\mathrm{ml})$ とし，一定時間（通常 1 時間）incubate して後直ちに medium を約 $4^{\circ} \mathrm{G}$ に泠却して から slice を除いて避心沈搌し，その上澄の 一定量（通常 $1 \mathrm{ml}$ ) の $\gamma$ 線計測を行い，次 式により $\mathrm{I}^{131}$ 摂取率を算定した。

$$
\mathrm{I}^{131} \text { 摂取率 }=\frac{\mathrm{M}_{0}-\mathrm{M}_{1}}{\mathrm{M}_{0}-\mathrm{b}} \times 100
$$

$\mathbf{M}_{0}$ : incubation 前の medium $1 \mathrm{ml}$ の count (back ground 在含む)

$\mathrm{M}_{1}$ ：1時間 incubation 後の medium $1 \mathrm{ml}$ の count (back groundを含む)

b : beak ground

2) 放出実験

$I^{131}$ を摂取せしめた slice は。その装面に 附看せる $\mathrm{I}^{131}$ を除去するために濾紙で氷分を

拭い去り， $1^{131}$ 危含ま口 medium $300 \mathrm{ml}$ 中で数秒間洗涤することを 3 回連続繰返して後，再び滤紙で十分

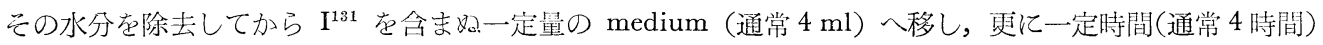
incubate して同様の操作の後，次式によつて $I^{131}$ 放出率を算出した.

$$
\mathrm{I}^{131} \text { 放出率 }=\frac{\mathrm{M}_{2}-\mathrm{b}}{\mathrm{M}_{0}-\mathrm{M}_{1}}
$$

$\mathrm{M}_{2}$ : 放出実験 (medium 4ml) 後に於ける medium 1 定量 (1 ml)の count (back groundを含吉)

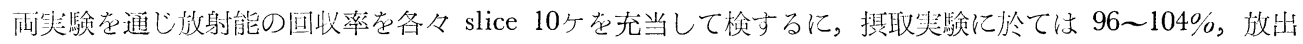
先験に於ては 92〜105\%の回仪率を得た。

実験計画は。すべて推計学的考察を按配して Gaddum ${ }^{52)}$ に準じて行つた。 slice は同一実験に於いては同 一の細織より作製し。一点に4〜6ケの slice 党充当した. 又 TSHの濃度は常に等間隔として対数に目盛

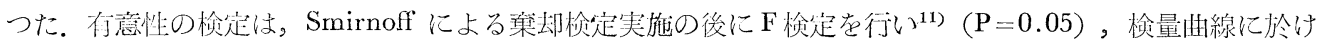
る直線性の検定は相関分析法 ${ }^{11)}$ に集じて行つた. TSH 当量の測定は，Gaddum ${ }^{52)}$ に準じて = $1 \times 2$ ” 又は 
“ $1 \times 3 "$ assay 法により行い, index of precision $\lambda$ を算出した.

\section{実 験 成 績}

\section{I . 牛甲状腺 slice の $1^{131}$ 搨取並びに放出に及ぼす各種実験的要約の検討}

1) incubation に於ける振湦の周期

摂取実験に於いて，振瀷しながら incubate せる場合と，静止のまま incubate せる場合との $\mathrm{I}^{131}$ 摂取率

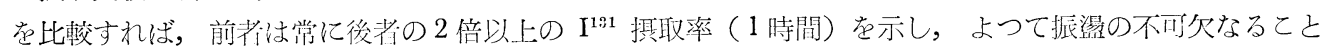
を知つた，振晹周期毎:分60回の場合と每分 120 回の場命とを比較したが， $I^{121}$ 摄取率に有意の产を認めなか つたので，振沙の回数は通常每分60回とした。

Fig. 1 The effect of temperature on radioiodide uptake. a total of 30 slices.

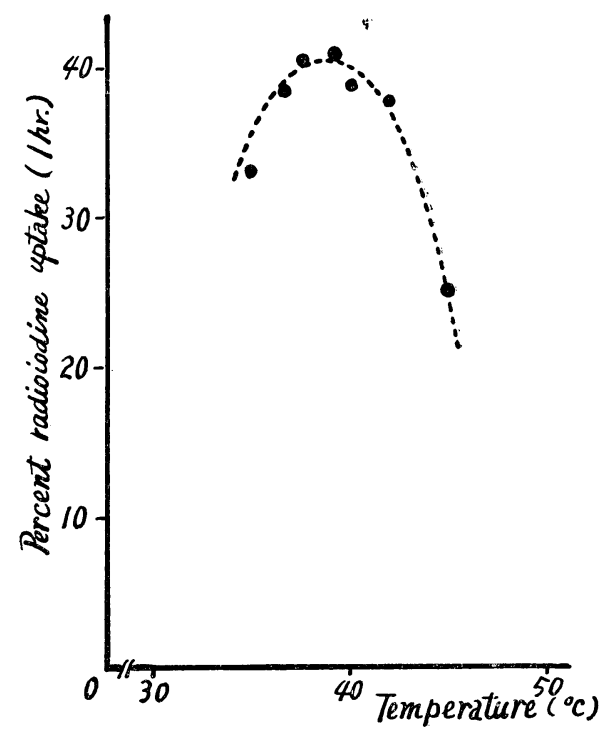

\section{2) incubation に於ける温度}

Warburg 装置 2 台を用い，一方者裳に $38^{\circ} \mathrm{C} と し て$

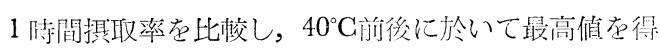
た(図 1 ).

3) slice の aging

通常の実験に於いては屠殺後 slice を作製して incubate を始めるまでに約 3 時間を経過する。

この間 slice は操作中を除いては約 $4{ }^{\circ} \mathrm{Cl}$ 亿保たれ， 乾燥から防がれているが，更に之展 1 時間延長してあ $\mathrm{I}^{131}$ 掑取率に有意の低下を認めなかつた。

4) medium $の \mathrm{pH}$

図 2 ) の如く $\mathrm{pH} 7.4$ 前後の medium に於いて 最高の䝮取率を得た。 Krebs-Ringer 氏液はアルカリ 側に傾くにしたがい，特に夏期に於いては，Ca の析 出在来し白濁する。 よつて加える $\mathrm{CaCl}_{2}$ の量を常に $1 / 2$ に減量して之を避けた，その為の摂取率の変化は 認められなかつた。

5) medium の容量

slice 重量 (100mg) 亿対する medium 容量 (V)

の比率を種々変化せしぬて incubate し， 1 時間 $\mathrm{I}^{131}$ 掑取率 $(\mathrm{U})$ との関係を失々刘数值に換算して図示 すれば，図 3 ) の如く直線関係が成立し，U・V=C の関係が認められる。乙れは slice 重量に対し medium の容量を一定にする必要のあるとと走す。1 1 ケの牛甲状腺より作製し得る slice の数（通常26ケ）と その大きさ，フラスコの容量及び incubation の時間（1時間を通常とする）を考虑して適当なる摂取率を 得る為, 以後 slice $100 \mathrm{mg}$ につき medium $4 \mathrm{ml}$ として実験を行つた.

\section{6) incubation の時間}

摂取実験に於いては 1 時間摂取率を至適ならしめる如く上記の条件を選らんだあのであるから摂取実験に 於ける incubation は通常 1 時間とした。

放出実験に於いて，I ${ }^{131}$ の放出は TSH を作用せしめるととにより卯制されて対照より低值を示す。而し てその值は incubation 開始後約 4 時間以降は一定值となり刘照との差も変らない. よつて放出実験に於け る incubation 時間は 4 時間とした（図4）。

7) medium に添加するCarrier 量

Carrier として medium 亿加える沃度加里が slice の I $^{131}$ 摂取に及ぼす影響は。図 5 ）の如くその沃度 濃度 $100 \mu \mathrm{g} / \mathrm{dl}$ 以下では抑制を示さず一定であるが。1000 $\mathrm{g} / \mathrm{dl}$ 以上になると著明なる抑制を示す。

放出実験に於いても $100 \mu \mathrm{g} / \mathrm{dl}$ 以下の濃度では始んど 影響を認めず，一定の放壮摔を示す（図 6 ), TSH 
Fig. 3 The effect of medium volume on radioiodine uptake

a total of 39 slices.

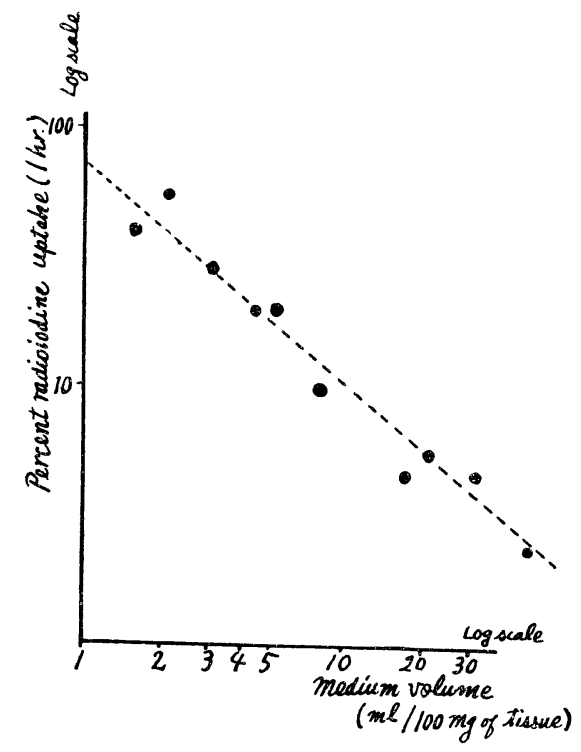

Fig. 4 Time study of radioiodine release

a total of 60 slices.

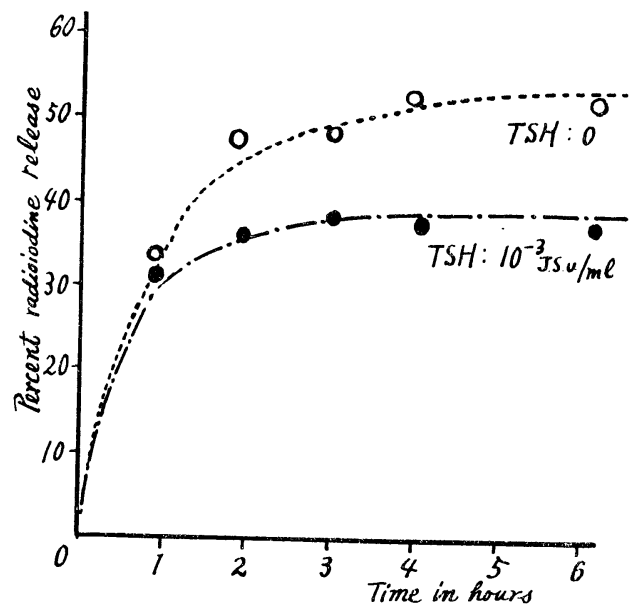

Fig. 2 The effect of medium-pH on radioiodine upłake

a total of 30 slices.

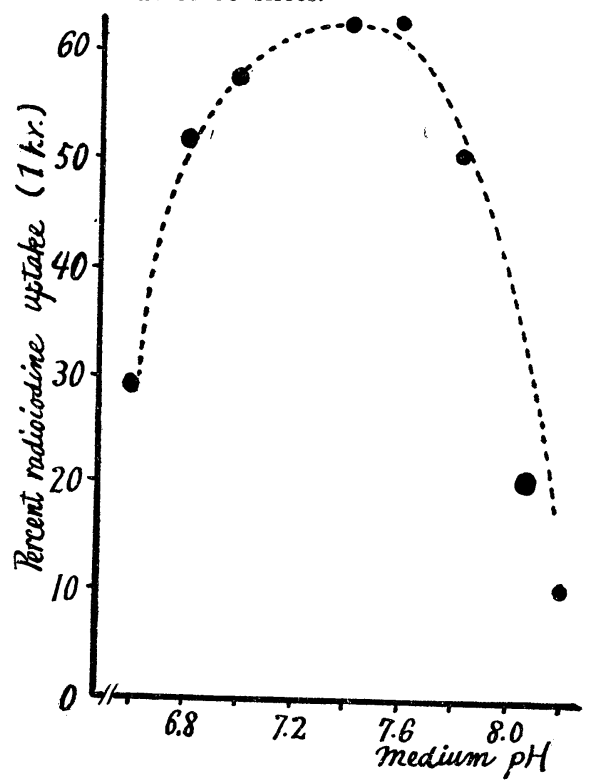

Fig. 5 Percent uptake from medium containing various concentrations of corrieriodide

a total of 39 slices

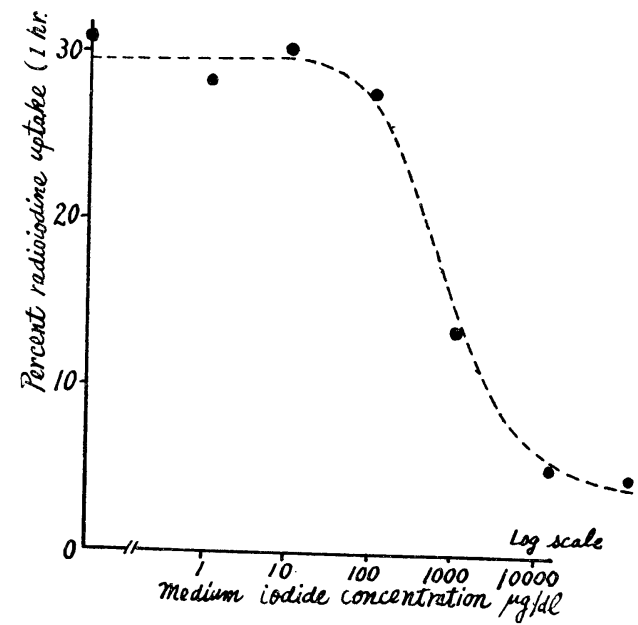

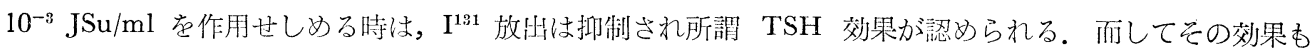
沃度濃度 $100 \mu \mathrm{g} / \mathrm{dl}$ 以下では充分発現されるが，図6）の如く $100 \mu \mathrm{g} / \mathrm{dl}$ 以上では TSH 效果も㴬減する ようである.よつて medium に加える沃度加里は沃度の終末湍度 $10 \mu \mathrm{g} / \mathrm{dl}$ 前後（通常攝取実験は $10 \mu \mathrm{g} /$ $\mathrm{dl}$ ，放出実験は $100 \mu \mathrm{g} / \mathrm{dl})$ とした。 この量では Jefferies ${ }^{(\mathrm{ig})}$ Goldsmith et al ${ }^{54)}$. の指摘する如き沃度による TSH の中和という危惧は全くないと考えられる。

8） medium に添加する mercazole の濃度 
Fig. 6 Effect of medium iodide concentration in release experiment

a total of 52 slices.

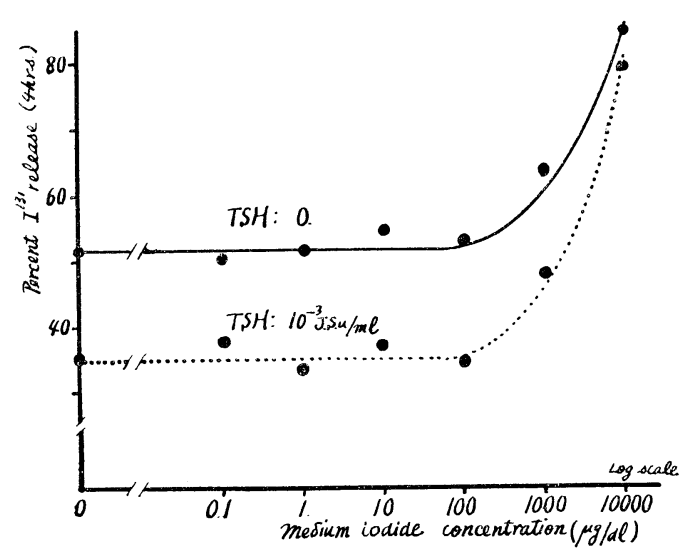

Fig. 7 Percent uptake \& release of $I^{131}$ incubated with various concentrations of mercazole a total of 90 slices.

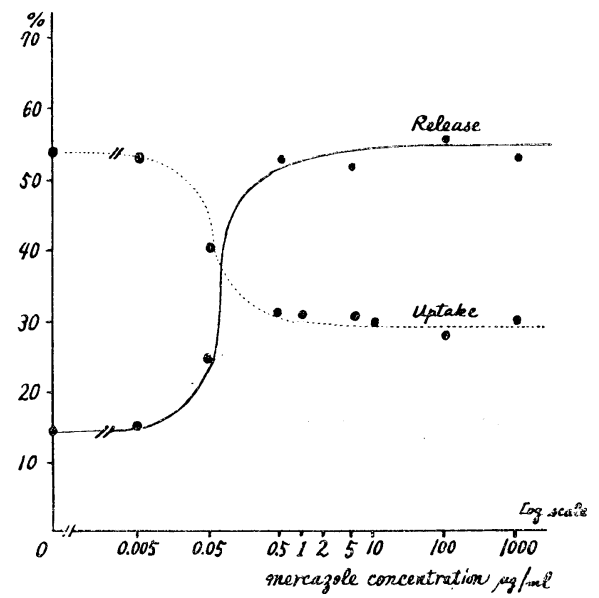

図7）に於いて点線で示される如く slice の $\mathrm{I}^{131}$ 摃取率は mercazole 濃度 $5 \mu \mathrm{g} / \mathrm{dl}$ にて既に著叨に低 下する。

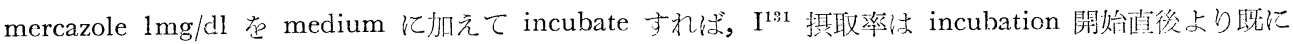
刘览にくらべて朋らかに低值走す（図 8 ）。

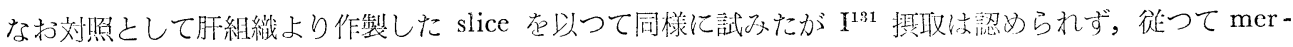
cazole の影響は見出せなかつた（図8）。

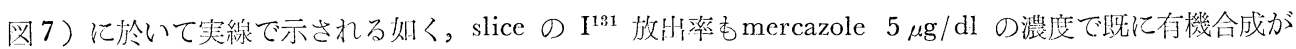

Fig. 9 The effect of mercazole on TSH doseresponse relationship in $\mathrm{I}^{131}$ release experiment

Fig. 8 The effect of mercagole on $\mathrm{I}^{131}$ a total of 60 slices uptake of thyroid and liver-slices
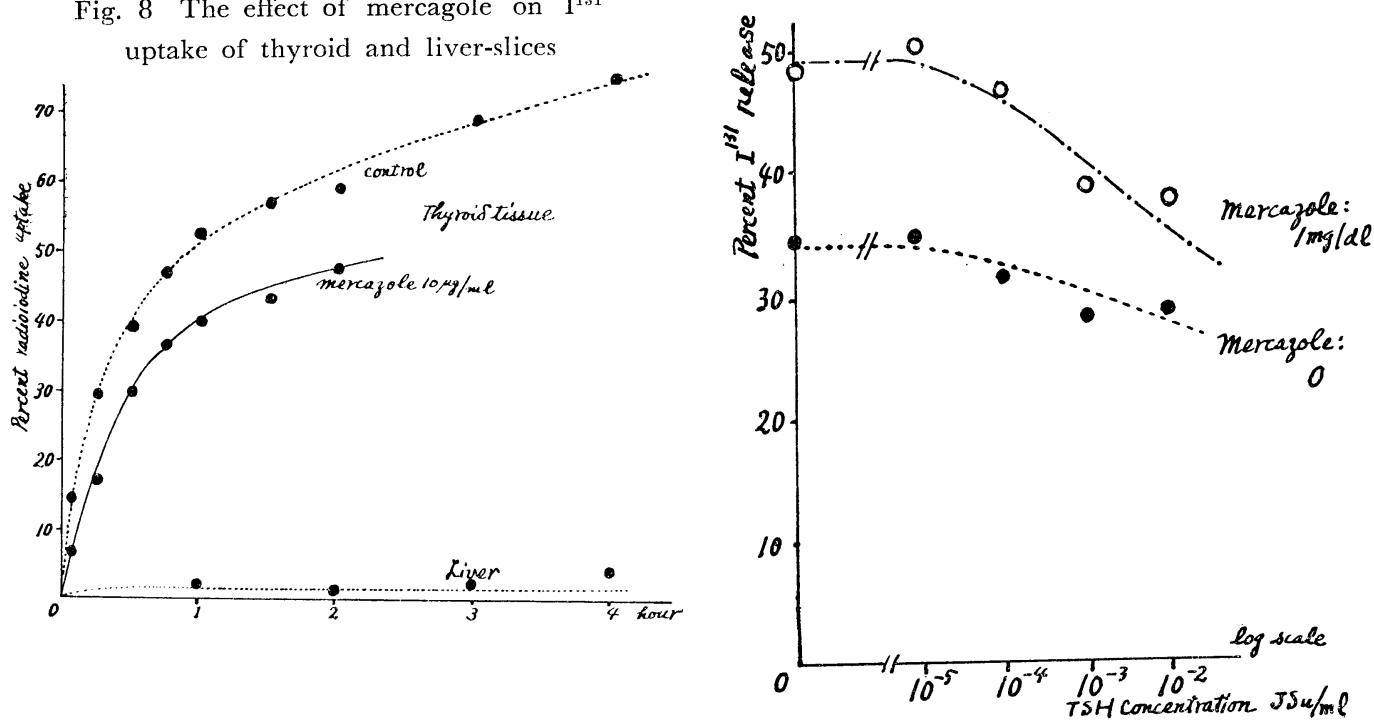
抑制されるためか明らかに増大する。 又 $\mathrm{I}^{131}$ 放出率に於いて見られる TSH 效果は， merazole の添加に よつて図9）に示される如く， mercazole 在添加せざる場合よりも dose-response curve の勾配が急峻之な る結果更に顕者に表わされる，故に mercazole を加えることは必要であり，その浱度は $1 \mathrm{mg} / \mathrm{dl}$ 程度で允 分であるといえよう。

\section{TSH 測定法への応用の可能性に就いて}

\section{1）㩒取実験に於ける TSH 効果}

牛甲状脉 slice の $I^{131}$ 掑取作用は，TSH 亿上つて促進される。著住は $I^{131}$ 在含む medium の TSH 濃 度を $10^{-1} ， 10^{-s}$ ，及び $0 \mathrm{JSu} / \mathrm{ml}$ とし, slice T量 $100 \mathrm{mg}$ に対し medium 容量を $4 \mathrm{ml}$ として時間的に夫 々の摂取率を比較した（図10）。

A comparison of uptake vs. release experiments

Table 1. a)

\begin{tabular}{|c|c|c|}
\hline TSH JSU/ml & $\%$ uptake \pm S.D. & $\mathrm{P}$ \\
\hline 0 & $48.5 \pm 3.6$ & \multirow{3}{*}{$\begin{array}{l}\text { n.s } \\
\text { n.s }\end{array}$} \\
\hline $10^{-3}$ & $54.3 \pm 6.8^{\prime}$ & \\
\hline $10^{-1}$ & $56.8 \pm 4.9)$ & \\
\hline
\end{tabular}

1 hour incubation,

$4 \mathrm{ml}$ of medium,

$100 \mathrm{mg}$ of tissue,

6 beakers per datum.

Fig. 10 A time study of radioiodine uptake in various concentrations of TSH

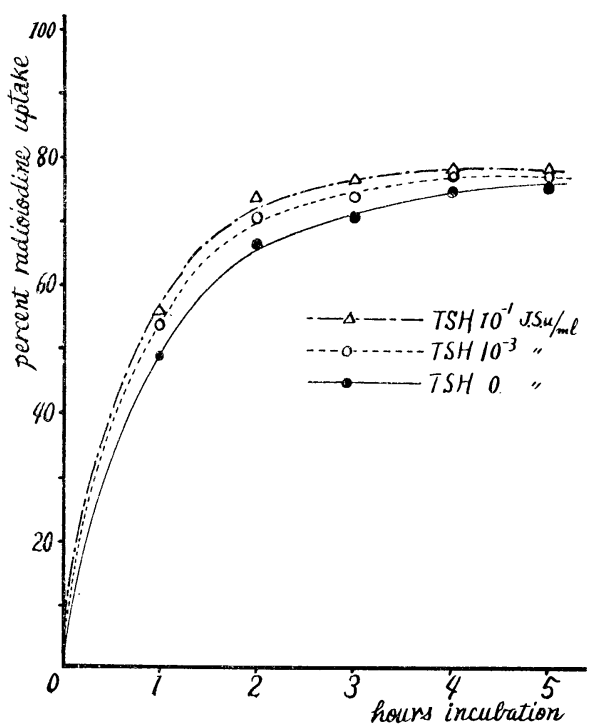

同一の incubation 時間に於いては, 図10) の如く TSH 濃度の大なる程之の $I^{131}$ 掑取 率は高值を示すが， incubation 洔間の長短 に拘らず TSH 效果は判然とせず。TSH 激 度老に刘応する $\mathrm{I}^{131}$ 摂取率に有意の差を認 めなかつ（表 1，a）。

次著者は。TSH がその作用を発揮する までに約 2 時間を要すると云う Brown Grant et al. ${ }^{41)}$ 及び Botrari ${ }^{38)}$ の報告を考虑し, TSH 及び I ${ }^{131}$ を同時に添加する代りに，予 约 TSH t作用させて後 $I^{131}$ 搨取を行つた。 先ず medium に於ける TSH 浱度を $10^{-1}$, $10^{-2}$ 及び $10^{-3} \mathrm{JSu} / \mathrm{ml}$ とし，2，3，4 及

Fig. 11 The effect of incubation periode with TSH prior to I ${ }^{131}$ uptake

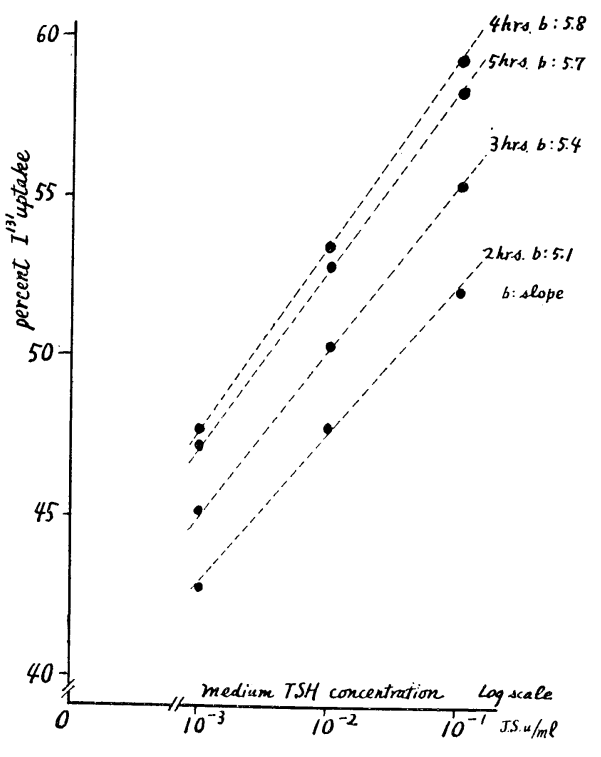


び 5 時間 incubate して後 $\mathrm{I}^{131}$ を含む medium そ移して 1 時間更に incubate し，TSH 作用時間が $\mathrm{I}^{131}$ 掑取率に及ぼす影響を検討すると，図11）の如く，約 4 時間 preincubate した場合に dose-response curve の勾配が最大となるととを認めた。 而してその場合 TSH $10^{-1} \sim 10^{-4} \mathrm{JSu} / \mathrm{ml}$ の範囲に於いて推計学上有意 の直線関係が認められた（図12，表 $1 \mathrm{~b})$ 。しかしながら摄取実験に於いては，同一組織より作製し同一条

Fig. 12 TSH dose-response relationship in $\mathrm{I}^{131}$ uptake previously incubated with TSH containing medium

a total of 26 slices

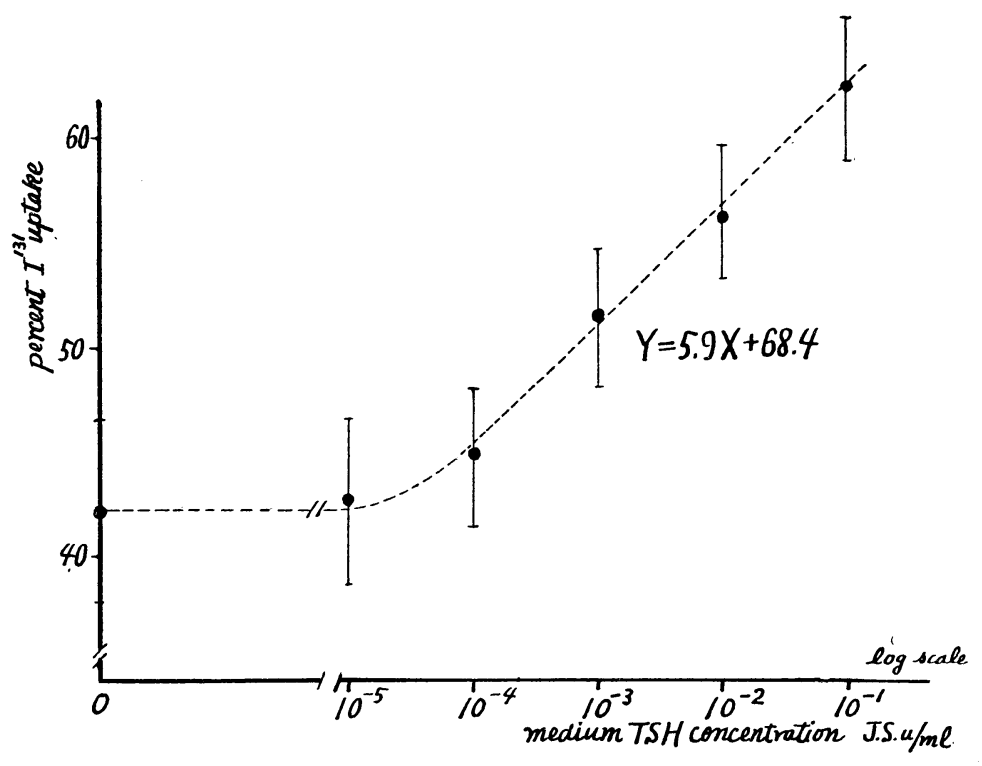

A comparison of uptake vs. release experiment

Table 1. b)

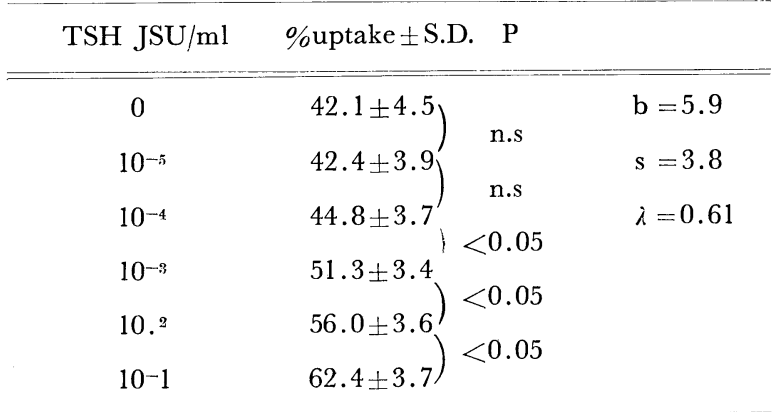

$4 \mathrm{ml}$. of medium/100mg of tissue,

$4 \mathrm{hr}$. perincubation with $\mathrm{TSH}$,

$1 \mathrm{hr}$. uptake,

4 beakers per datum.
件で incubate した slice の間にあ つてあ $\mathrm{I}^{131}$ 摂取率には可成りの変動 があり，組織を異にせる場合 1 時間 掑取率は $8 \%$ 以下より $80 \%$ 以上に及 ぶ差異があつてその変動は甚だしく， 有意の直線関係の得られ婸合が屯 しろ多いことをその後に於ける検討 によつて認めた。

2）放出実験に於ける TSH 効果 Bakke et $\mathrm{al}^{322}$. 亿準じ slice 100 $\mathrm{mg}$ 亿つき $\mathrm{I}^{131}$ 含有 medium $4 \mathrm{ml}$ を用い， 1 時間 incubate して ${ }^{131}$ を蛽取せしぬ，続いて TSH を含む medium（I $I^{131}$ を含まず） $4 \mathrm{ml}$ の中 で更に 4 時間 incubate して $\mathrm{I}^{131}$ を 放出せしめた場合，拱取 $I^{131}$ に対

する放出率と TSH 濃度の対数值との間には，TSH 濃度 $10^{-2} \sim 10^{-5} \mathrm{JSu} / \mathrm{ml}$ の範团に於いて推計学上有 意の直線関係が認められた（図13，表1 c). 
A comparison of uptake vs. release experiments Table 1. c)

\begin{tabular}{|c|c|c|}
\hline TSH JSU/ml & $\%$ relcase \pm S.D. $\quad \mathrm{P}$ & \multirow{4}{*}{$\begin{array}{l}\mathrm{b}=4.7 \\
\mathrm{~s}=3.3 \\
\lambda=0.69\end{array}$} \\
\hline 0 & $49.1 \pm 3.9$ & \\
\hline $10^{-5}$ & $48.8 \pm 4.0$ & \\
\hline $10^{-4}$ & $42.0 \pm 3.7$ & \\
\hline $10^{-3}$ & $37.3 \pm 2.7>0.03$ & \\
\hline $10^{-2}$ & $32.6 \pm 2.8$ & \\
\hline $10^{-1}$ & $31.9 \pm 3.1)$ & \\
\hline
\end{tabular}

$4 \mathrm{ml}$ of medium/100mg of tissue,

1hr. loading,

4 hr. release,

4 beakers per datum.
即ち TSH は in vitro に於いて 甲状腺組織の $\mathrm{I}^{131}$ 畒積ないしは保持 能を增進し，結果として medium 中への放任在抑制するものと若えら れる。

木实験に於ける放出率の動搯は， 同一組紗より作裝せる slice の閔で は摂取等験に於ける摂取率の動摇 に比心゙て少なく， dose-response の 可現性に於いても優れており，実用 の四能性汃多分に考光られる。しか しながらその dose-response の動採 が年間を通じて諗められ，とくに気 温の上显寸る夏期に於いては，その 勾唒が䌊徐となり，全く平坦化する 場合があり，而してその precision

index $\lambda$ の值は一般に高值を示した（裴 $2 \mathrm{~A}$ ）。

Fig. 13 Typical dose-response curve obtained wite "Pretiron" TSH

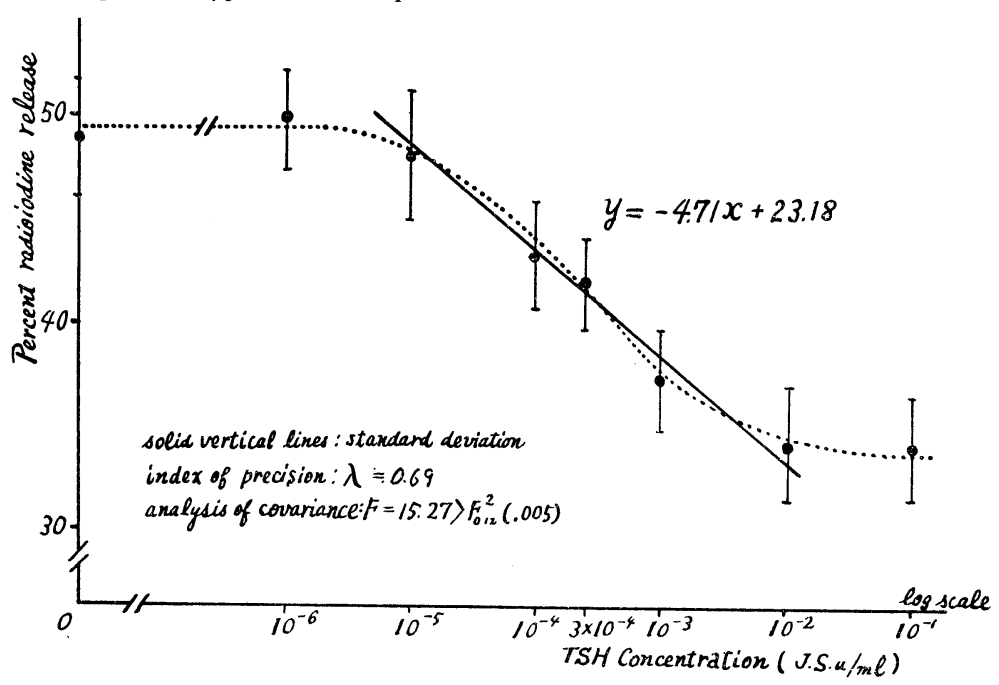

著者は放出実験に就いて㭘馀を重ねた絬果，木法に於ける入值を小ならしめるには，その dose-response curve の公唒を急峻ならしめる以外に方法がないと云う結論に達し，次の如く本法を改めた。 即ち $I^{131}$ 摂 取は slice $100 \mathrm{mg}$ に対して medium 量を $4 \mathrm{ml}$ として同様に行い，1時間 incubateした後この medium $1 \mathrm{ml}$ を計測して摂取值を算定，次いで放出実験に於いては， medium 量を $3 \mathrm{ml}$ に減量して 4 㭙間 incubateした後，その medium $2 \mathrm{ml}$ を計測し，次の如く放出率指数を算出した。

放出率指数 $=\frac{\mathrm{M}_{3}-\mathrm{b}}{\mathrm{M}_{0}-\mathrm{M}_{1}} \times 100$

$\mathbf{M}_{0}$ : incubation 前の medium $1 \mathrm{ml} の$ count (back ground を含む)

$M_{1}$ : 1 時間 incubation 後の medium $1 \mathrm{ml}$ の count (back ground 友全む) 
$\mathrm{M}_{3}$ : medium $3 \mathrm{ml}$ に於いて 4 時間放出後の medium $2 \mathrm{ml} の$ count (back ground を含む)

$\mathrm{b}$ : back ground

斯く改めることによつて，図14.の如く dose-respons curve の勾配は大となり，その多少の变動にも拘ら ずえ值を低值に止らしめることが出来た（表 $1 ， \mathrm{~d}$ 及び 表 $2 ， \mathrm{~B}$ ）.

A comparison of uptake vs. release experiments

Table 1. d)

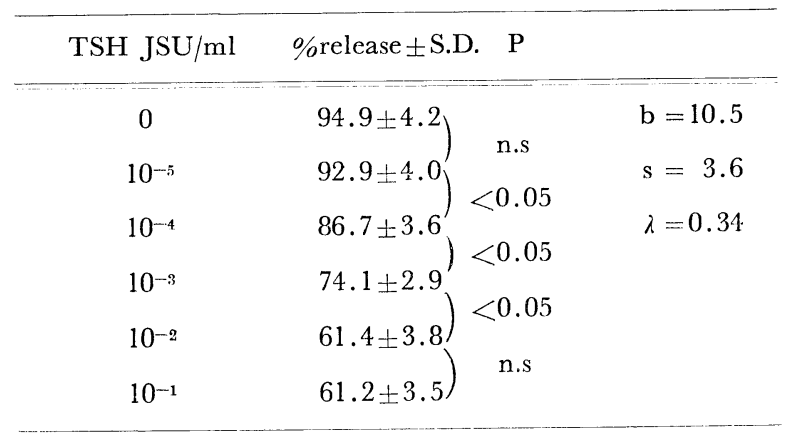

lhr loading,

$4 \mathrm{ml}$ of medium/100mg of tissue,

$4 \mathrm{hr}$. release. ( $3 \mathrm{ml}$ of medium) counted

twice the medium,

4 beakers per datum.

Fig. 14 TSH dose-response relationship

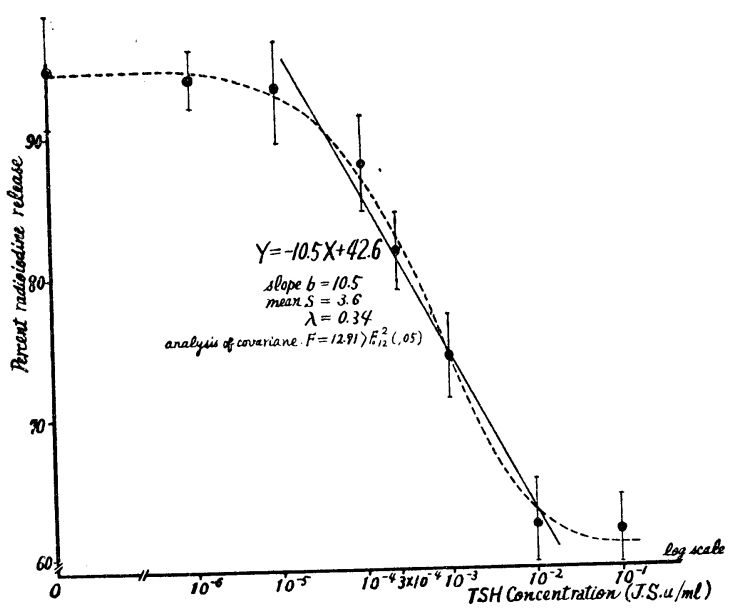

III 放出実験に於いて medium 中 へ放出される $I^{191}$ の定性的分 析

放出実験に於いて medium 中に 放出される $I^{131}$ は，incubation 時 間が短時間であること，及び有機合 成阻止の目的で mercazole を添加 せること等よりして無機の $\mathrm{I}^{131}$ であ ることが推定される。著者はこれを 立証するため次の実験を行つた。

1) Taurog et $\mathrm{al}^{92)}$. 飞準じ，放出 实験直後の medium に同容の $10 \%$ 3 塩化醌酸を加えてよく混和後遠心 沈澌を行つてその上澄を除き，更に 同量の $5 \% 3$ 塩化醋酸を加えて 2 回 同様の操作を行い，その沈渣を $10 \%$ 吘性ソーダで溶解して counting tube そ移し, well-type scintillat ion counter で $\gamma$ 線計測を行つた. $\mathrm{TSH}$ 濃度 $10^{-1}, 10^{-3} \mathrm{JSu} / \mathrm{ml}$ 及 びOで incubation を行つた後の medium を夫々同様に操作して計測 したが，何れにも全く放射能を検出 せず，即ち放射能はすべて上澄に移 行することを認めた。 このととより 少くとも $\mathrm{I}^{131}$ は thyroglobulin の形 では放出されないことを確認した。

2) 更に paper chromatography によつて定性的分析を行うために，

Gross et $\mathrm{al}^{59}$. に做い同じ medium に同容の n-butanol を加えて振嚍 抽出の後蒸発乾固せしめ n-butanol で再溶解せしぬた泜，或は medium そのままを，東洋滤紙 No. 51 亿，原線に於ける放射能（展開前）が G -M計数管で $2 \mathrm{~cm} の$ 距離で測定して，およそ 1000 c.p.m. 以上になる加く塗抹した.

展用液は Gross et $\mathrm{al}^{59)}$. そ準じ n-butanol-dioxane-2N-ammonia (4:1:5) の混合上澄, 及び Roche et $\mathrm{al}^{\mathrm{95})}$ 亿準じ n-butanol一醋酸一水(78:5:17) を用い，夫々一次元上昇法により paper chromatography を行つた。 室温で $25 \mathrm{~cm}$ 展開せしめて後, 滤紙は室温で乾燥させ, 原線より $0.5 \mathrm{~cm}$ 每に G-M 計数管で $\beta$ 線 計測を行い， paper radiochromatogram 在作製した（図15）. 
chromatography 実施の際，1-thyroxine $\left(\mathrm{T}_{4}\right), 3 \cdot 5 \cdot 3^{\prime}$-1-triiodothyronine, 3,3'-diiodothyrosine 及び Na $\mathrm{I}^{131}$ ⿸ 在 standard として同様に展開せしめ, ninhydrin 溶液にて発色せしもて，その $\mathrm{Rf} よ り I^{131}$ 含有物 の認定を行つた。

Fig. 15 Radiochromatograms of the medium after the release experiment
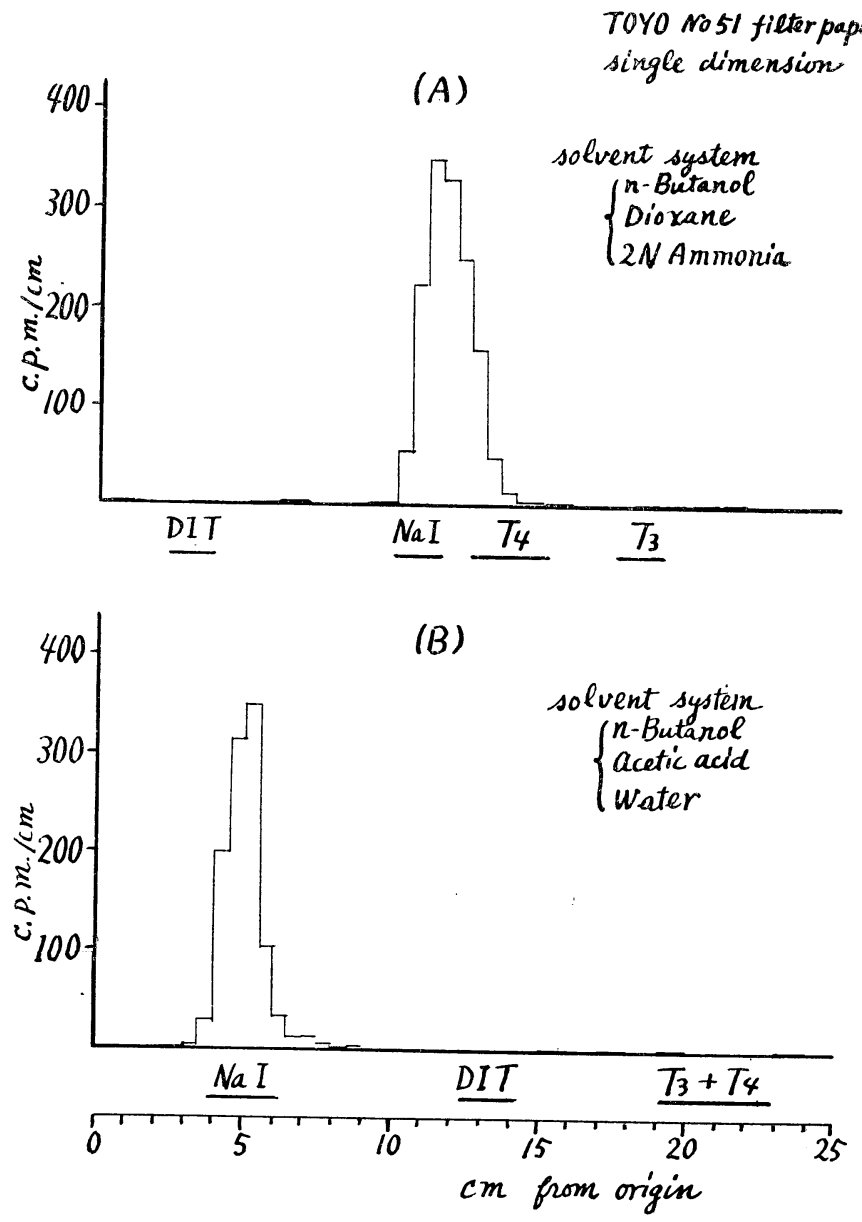

図15 (A) の如く n-butanol-dioxane-2N-ammonia 尼展開液とせる場合では， $\mathrm{T}_{4}$ との分離が不充分で あるため無機の $I^{1: 1}$ であるととを認定することは困難であるが， n-butanol一醋酸一水の system で展開也 万場合は（図 $15(B)) T_{4}$ と無機 I との分皠が良好であるため，放非実験に於いて medium 中に放出される $I^{131}$ はすべてが無機の $I^{131}$ であることを確認し得た。

IV Junkmann-Schoeller 単位と USP 単位との比較

Standard として著者が用いたドイツ Schering 社製 Pretiron (021B) の1モルモット単位は1 JS単位 とされているが，著者は United States Pharmacopoeia の USP Thyrotropin Reference Standard (1 銫約 $20 \mathrm{mg}, 1 \mathrm{mg}$ は 0.074 USP TSH unit) を入手したので Gaddum ${ }^{22}$ に做い 6 point assay 又は 4 point assay を適用して両者の比較を行つた。 その結果は（表4）に示される如く1USP 単位は活 11.4JS 单位に相当し, Hays \& Steelman ${ }^{62)}$ 又は小倉等 ${ }^{20)}$ の成績むこれに近い, 
Table 2. Statistical analysis of the release experiment

A)

\begin{tabular}{l|r|r|r|c|c}
\hline month & $\begin{array}{c}\text { no. of } \\
\text { assay }\end{array}$ & $\begin{array}{c}\% \text { uptake } \\
\text { mean }\end{array}$ & $\begin{array}{c}\text { s } \\
\text { mean }\end{array}$ & $\begin{array}{c}\text { b } \\
\text { mean }\end{array}$ & $\begin{array}{c}\text { i (s/b) } \\
\text { mean } \pm \text { S.D. }\end{array}$ \\
\hline Mar. & 9 & 31.7 & 3.9 & 6.8 & $0.57 \pm 0.097$ \\
Apr. & 6 & 38.2 & 3.1 & 6.1 & $0.50 \pm 0.091$ \\
May. & 4 & 29.8 & 3.9 & 6.9 & $0.57 \pm 0.132$ \\
June & 6 & 25.6 & 3.4 & 4.1 & $0.83 \pm 0.129$ \\
July & 11 & 8.9 & 4.2 & 2.8 & $1.50 \pm 0.735$ \\
Aug. & 12 & 11.7 & 4.8 & 2.7 & $1.84 \pm 0.897$ \\
Sep. & 14 & 26.3 & 4.0 & 4.9 & $0.82 \pm 0.168$ \\
Oct. & 6 & 37.2 & 3.7 & 5.8 & $0.64 \pm 0.218$ \\
Nov. & 7 & 31.9 & 3.7 & 7.7 & $0.48 \pm 0.132$ \\
Dec. & 11 & 38.1 & 4.3 & 5.6 & $0.56 \pm 0.095$ \\
Jan. & 5 & 37.6 & 3.4 & 6.9 & $0.49 \pm 0.077$ \\
Feb. & 5 & 43.7 & 3.3 & 6.1 & $0.54 \pm 0.101$ \\
\hline B) & & & & & \\
\hline Jan. & 6 & 35.9 & 4.2 & 14.3 & $0.29 \pm 0.102$ \\
Feb. & 8 & 42.4 & 4.3 & 15.9 & $0.27 \pm 0.114$ \\
Mar. & 10 & 33.8 & 3.5 & 13.8 & $0.25 \pm 0.173$ \\
Apr. & 8 & 40.0 & 4.4 & 14.7 & $0.30 \pm 0.100$ \\
May. & 6 & 24.7 & 4.1 & 11.8 & $0.35 \pm 0.137$ \\
June & 6 & 28.2 & 3.7 & 8.2 & $0.45 \pm 0.156$ \\
July & 7 & 14.7 & 4.2 & 6.1 & $0.62 \pm 0.179$ \\
\hline
\end{tabular}

B) : obtained from the improved method.

考 案

睍在までに報告された多数のTSH 測定法のうち，人血中の微量 TSH が測定可能と'思われる方法の认 在挙げると，およそ表３）の如くである．蛋白ホルモンであるTSH が未だ純粋にに抽出されるに至らず， 又化学構造屯不明な現在にあつては, その生物学的作用を指標とする bioassay 以外適当な測定法はない. 而してこれらの諸測定法は夫々異なる TSH 製剤を Standard に使用している為敩密には無論比較出来な い.一般には $1 \mathrm{USPu}=1$ 国際単位 ${ }^{81)} \fallingdotseq 10 \mathrm{JSu}^{(2) 20)}$ とされ，著者屯ほぼ同様の成績を得たが， Lamberg ${ }^{69}$ 亿 よれはば 1USPu は約 $2 \mathrm{JSu}$ であり，又，Overbeek et $\mathrm{al}^{77}$.によれば 1 国際単 報告者によつて多少の差異があり， Standard preparation ひいては単位の統一が要望される所以であ ろ.

TSH の作用による甲状腺の形態学的変化を指慗とする形態学的方法は，何れむ組織標本作製を必要とす るために手技上煩䧺であり, 迅速に実施出来難いので近年は簡単迅速に垁施出来てしかも主観の入り難い生 化学的方法，就中放射性同位元素を tracer として使用する方法が多く陚みら礼る傾向にある。

生化学的方法之は TSH の作用によつてもたらされる阵状腺の生化学的変化を指標とする測定法であるが， in vivo に於いて放射性同位元素を tracer に使用した方法のうち，早くから追試されたヒナ $\mathrm{P}^{32}$ 掑取率測 定法 (Lamberg ${ }^{67)}$ ) は，その改良汒と看做される Greenspan et al ${ }^{157}$. の方法を以つてしても。人血中 TSH

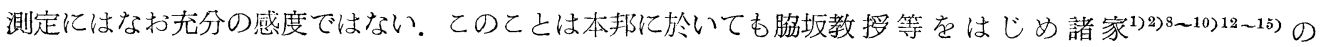


Table 3. Some of the chief metheds for quantitative assay of TSH

(A) histological techniques

\begin{tabular}{|c|c|c|c|c|c|}
\hline thyroidal end point & $\begin{array}{l}\text { No. of } \\
\text { Literature }\end{array}$ & authors & $\begin{array}{c}\text { experimental } \\
\text { animals }\end{array}$ & $\begin{array}{l}\text { usable range } \\
\text { J.S. u/ml }\end{array}$ & $\lambda$ \\
\hline colloid droplet & 46) & De Robertis ('48) & guinea pigs & $0.0002 \sim 1$ & \\
\hline$" 1$ & 47) & Dvoskin $\quad$ ('48) & chicks & $0.005 \sim 0.5$ & \\
\hline $\mathrm{MCH}$ & 44) & D'Angelo et al. ('50) & starving tadpoles & $0.0005 \sim 0.05$ & \\
\hline " & 42) & Brown et al. ('56) & " & $0.001 \sim 0.05 \triangle$ & \\
\hline$\Delta \mathrm{E} \%$ & 16) & Kôno et al. ('58) & " & $0.0001 \sim 0.1$ & 0.198 \\
\hline$\Delta \mathrm{E} \%$ & 91) & Tala ('53) & guinea pigs & $0.00001 \sim 10.0$ & \\
\hline "1 & 82) & Piotti ('57) & $" 1$ & $0.00005 \sim 5.8$ & \\
\hline
\end{tabular}

$\mathrm{MCH}:$ mean acinar cell heights, $\Delta \mathrm{E} \%$ : percentage of epithelium

(B) biochemical techniques (employing radioisotopes)

a) in vivo

\begin{tabular}{|c|c|c|c|c|c|c|c|}
\hline $\mathrm{P}^{32}$, uptake & & $67)$ & Lamberg ('53) & chicks & 0.005 & $\sim 0.05$ & \\
\hline "I & & 15) & Shimanuki ('58) & 11 & 0.002 & $\sim 0.01^{*}$ & \\
\hline $\mathrm{P}^{32}$, uptake & $55)$ & $56)$ & Greenspan et al. ('56) ('59) & " & 0.00025 & $\sim 0.005^{*}$ & 0.34 \\
\hline "I & & 1) & Wakisaka et al. ('57) & " & 0.0068 & $\sim 1.36$ & \\
\hline$" 1$ & & 12) & Shizume et al. ('57) & 11 & 0.001 & $\sim 0.01$ & \\
\hline "1 & & 13) & Miyai et al. ('57) & "1 & 0.01 & $\sim 0.2$ & \\
\hline "1 & & 14) & Okishio et al. ('57) & 11 & 0.01 & $\sim 0.1$ & \\
\hline $\mathrm{h}-\mathrm{I}^{131}$, release & & 53) & Gilliland et al. ('53) & "1 & 0.025 & $\sim 0.4$ & \\
\hline $\mathrm{I}^{131}$, uptake & & 71) & Levey et al. ('56) & rats & 0.00065 & $\sim 0.0025^{*}$ & 0.24 \\
\hline "l & & $36)$ & Bates et al. ('57) & chicks & 0.00167 & $\sim 0.0267 *$ & 0.20 \\
\hline "1 & & 51) & Frey et al. ('59) & 11 & 0.0003 & $\sim 0.01^{*}$ & 0.20 \\
\hline 11 & & $56)$ & Greenspan et al. ('59) & "1 & 0.001 & $\sim 0.01^{*}$ & 0.22 \\
\hline $\mathrm{h}-\mathrm{I}^{131}$, release & 27) & 28) & Adams et al. ('55,) ('57) & guinea pigs & $\begin{array}{l}0.0001 \\
0.00005\end{array}$ & $\begin{array}{l}\sim 0.003 \triangle \\
\sim 0.0015 \triangle\end{array}$ & \\
\hline "1 & & 74) & Mc Ckenzie ('58) & mice & 0.000025 & $5 \sim 0.0016^{*}$ & 0.24 \\
\hline "I & & 17) & Irie et al. ('59) & mice & 0.0002 & $\sim$ & \\
\hline
\end{tabular}

h-I $\mathrm{I}^{131}$ : hormonal $\mathrm{I}^{131}$

b) in vitro

\begin{tabular}{|c|c|c|c|c|c|}
\hline $\mathrm{P}^{32}$ uptake & 49) & Florsheim et al. ('57) & $\begin{array}{l}\text { bovine thyroid } \\
\text { slices, }\end{array}$ & $0.0002 \sim 0.02^{*}$ & 0.22 \\
\hline $\begin{array}{l}\text { weight increase } \\
\text { of slices }\end{array}$ & 33) & Bakke et al. ('57) & 11 & $0.00001 \sim 0.0002^{*}$ & 0.28 \\
\hline $\mathrm{I}^{131}$, uptake & 38) & Bottari ('57) & $\begin{array}{l}\text { thyroid fragmen - } \\
\text { ts of guinea pigs, }\end{array}$ & $0.00001 \sim 0.1 \triangle$ & \\
\hline "I & 18) & Noguchi et al. ('59) & $\begin{array}{l}\text { bovine thyroid } \\
\text { slices, }\end{array}$ & & 2.03 \\
\hline $\mathrm{h}-\mathrm{I}^{131}$, release & 39) & Bottari et al. ('58) & $\begin{array}{l}\text { thyroid fragmen - } \\
\text { ts of guinea pigs, }\end{array}$ & $0.000001 \sim 0.01 \triangle$ & \\
\hline $\mathrm{I}^{131}$, release & 32) & Bakke et al. ('56) & $\begin{array}{l}\text { bovine thyroid } \\
\text { slices, }\end{array}$ & $0.000008 \sim 0.00004 *$ & \\
\hline$\prime \prime$ & 19) 20) & Ogura et al. ('57) & $" 1$ & $0.00001 \sim 0.01$ & \\
\hline $\mathrm{I}^{131}$, uptake & 61) & Hart et al. ('59) & $\begin{array}{l}\text { beef thyroid } \\
\text { minces, }\end{array}$ & $\sim 0.01$ & \\
\hline
\end{tabular}


検討により明らかにされている。 ラッテ $I^{131}$ 揕取率測定法 (Levey et $\mathrm{al}^{71)}$ ) 及びヒナ $\mathrm{I}^{131}$ 摂取率測定法 (Bates \& Cornfield ${ }^{36}$ ) は，何れも正確性に於いては充分のようであるが，感度に於いて少ることが最近 Greenspan et $\mathrm{al}^{56)}$ ) の追試であ認められている。ヒナを用いた Gilliland \& Strudwick ${ }^{53)} の I^{131}$ 放出法は奖 用に供するにはなお感度不足である. Adams \& Purves ${ }^{27) 28)}$ 亿よる海椇 $\mathrm{I}^{131}$ 放出法, 或はその変法と看做さ れる McCkenzie ${ }^{74)}$ の甘日ねずみ $\mathrm{I}^{131}$ 放出法は，感度及び正確性に於いて優れた方法であるが，手技上困難 であるため，本邦に於ける入江等 27 の追試では満足すべき感度が得られていない．

以上はすべて in vivo に於ける bioassay であるが。これらに比較して最近着目された in vitro に於け る bioassay は，Bakke et $\mathrm{al}^{32}$. の指摘する如く，小量の被験物哲で遂行出来，又手技上簡算で比較的进速

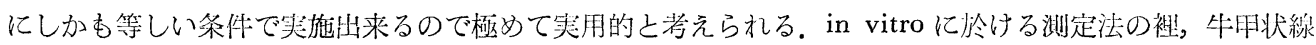
slice を用い, phospholipid fraction そ於ける $\mathrm{P}^{32}$ turnover を指䌘とする Florsheim et al ${ }^{49)}$. の方法は，悠

Table 4. A) Comparison of USP unit and Junkman-Sehoellcrunit by 6 or 4 point assay

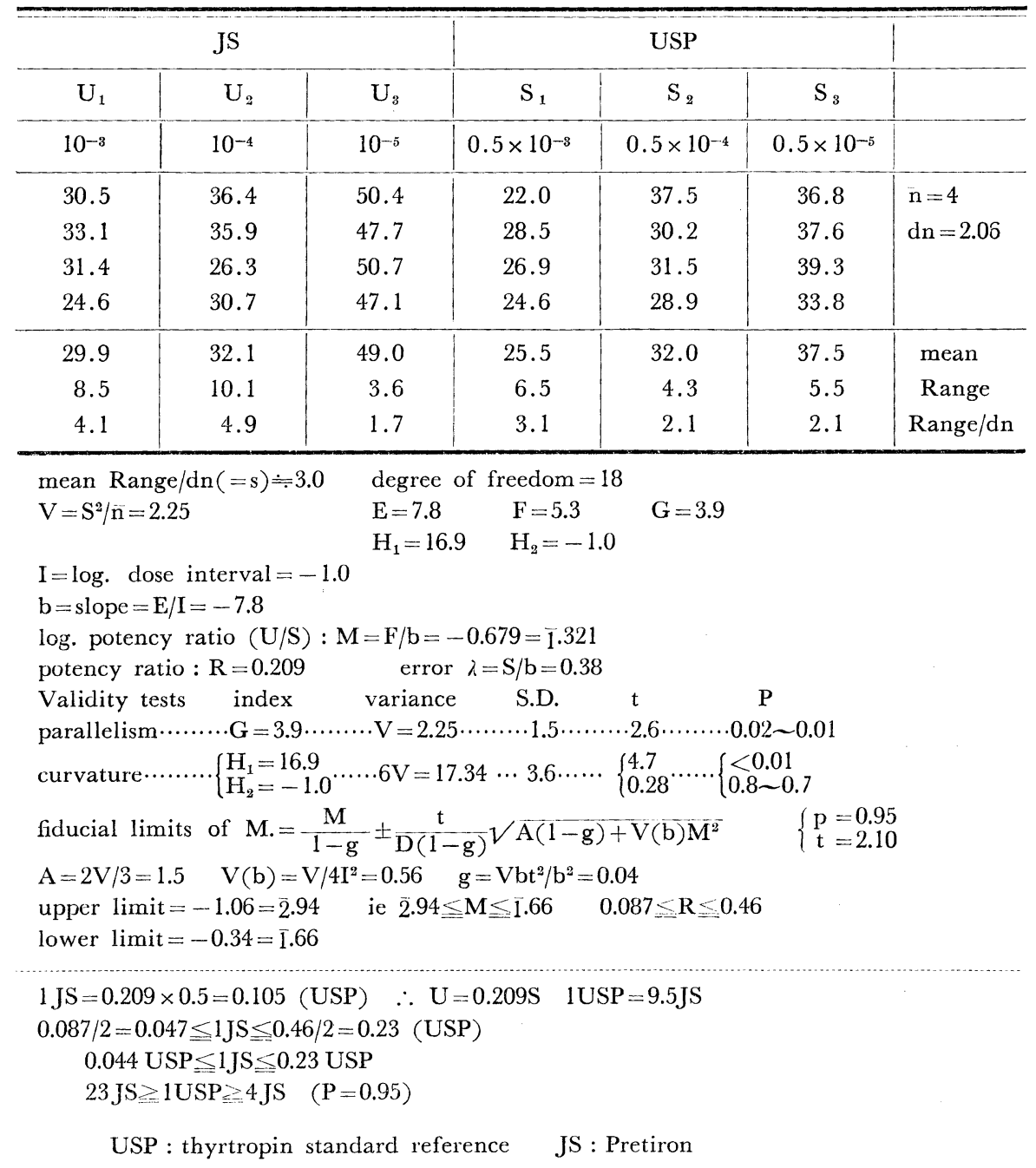


B)

\begin{tabular}{r|c|c|c|l}
\hline \multicolumn{2}{c|}{ JS } & \multicolumn{2}{|c|}{ USP } & \\
\hline $\mathrm{U}_{1}$ & $\mathrm{U}_{2}$ & $\mathrm{~S}_{1}$ & $\mathrm{~S}_{2}$ & \\
\hline $10^{-3}$ & $10^{-5}$ & $0.5 \times 10^{-3}$ & $0.5 \times 10^{-5}$ & \\
\hline 47.8 & 59.5 & 34.3 & 58.2 & \multicolumn{1}{c}{$=4$} \\
42.2 & 64.7 & 31.6 & 54.0 & $\mathrm{dn}=2.06$ \\
42.4 & 69.5 & 29.6 & 56.7 & \\
42.3 & 58.8 & 30.9 & 58.2 & \\
\hline 43.7 & 63.1 & 31.6 & 56.8 & mean \\
5.6 & 10.7 & 4.7 & 4.2 & Range \\
2.7 & 5.0 & 2.3 & 2.0 & Rang/dn \\
\hline
\end{tabular}

mean Range $/ \mathrm{dn}(=\mathrm{s}) \doteqdot 3.0 \quad$ degree of freedom $=12$

$\mathrm{V}=22.5 \quad \mathrm{E}=22.3 \quad \mathrm{~F}=9.2 \quad \mathrm{G}=-5.8$

$\mathrm{I}=-2.0$

$\mathrm{b}=22.3 /-2=-11.1$

$\mathrm{M}=-0.82=1.18$

$\mathrm{R}=0.151 \quad$ error $\lambda=\mathrm{S} / \mathrm{b}=0.27$

validity tests index variance S.D. $t \quad P$ parallelism $\cdots \cdots \cdots \cdot \mathrm{G}=-5.8 \cdots \cdots \cdots \mathrm{V}=2.25 \cdots \cdots \cdots \cdot 1.5 \cdots \cdots \cdots \cdot 3.9 \cdots \cdots \cdots .0 .01 \sim 0.001$

fiducial limits of $\mathrm{M}:\left\{\begin{array}{l}\mathrm{P}=0.95 \\ \mathrm{t}=2.18\end{array}\right.$

$\mathrm{A}=\mathrm{V}=2.25 \quad \mathrm{Vb}=0.14 \quad \mathrm{~g}=0.006$

upper limit $=-1.013=\overline{2} .987$ ie $\overline{2} .987 \leqq \mathrm{M} \leqq \overline{1} .373$

Lower limit $=-0.627=1.373 \quad 0.0971 \leqq R \leqq 0.236$

$$
\begin{aligned}
& 1 \mathrm{JS}=0.076 \mathrm{USP} \quad 1 \mathrm{USP}=13.3 \mathrm{JS} \\
& 0.049 \mathrm{USP} \leqq 1 \mathrm{JS} \leqq 0.118 \mathrm{USP} \\
& 20 \mathrm{JS} \geqq 1 \mathrm{USP} \geqq 8 \mathrm{JS} \quad(\mathrm{P}=0.95)
\end{aligned}
$$

度が低いために寒用には供し得ないと思われる。海獏甲状腺組織片の $I^{131}$ 掑取率を指標とする Bottari ${ }^{388} の$ 方法は高感度と比輘的広い測定可能範用を有し，既に動物実験に応用されているが，本邦に於いて野口等18) が牛甲状腺 slice を用いて追試した成績では，その正確性に著明な変動があり，TSH 定量法として適当で ないと認めている．その追武方法に就いては疑義なしとしないが，Bottari ${ }^{38)}$ の原法を加味して行つた著者の 牛甲状腺 slice $\mathrm{I}^{131}$ 摂取率測定法に於いても，必ずし屯常に有意の検量曲線が得られなかつたととは既述の 通りであり，促つて本法の実用可能性は少ないと考えられる。更に Bottari et $\mathrm{al}^{399}$.の行つた海埧甲状腺組 織片による $\mathrm{PBI}^{131}$ 放出法は感度，測定可能範囲共に優れた方法と思われる。 その正䃓性に就いての記載は ないが追試值すると云えよう。

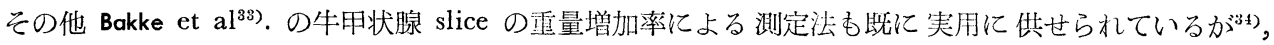
放射性同位元素を用いず，従つて slice の湿重量を測定する手技上の困難，長時間の shaking incubation による slice の崩壊，及び TSH に対する特異性に懸念がある.

牛甲状腺 slice の $\mathbf{I}^{131}$ 摂取並びに放出を指標とするTSH測定法に於いて，先ずその $I^{131}$ 掑取率を指標之 する方法が TSH 定量法として不適当であるてとは既に著者む指摘した。 小倉等 ${ }^{193}$ は $10^{-3} \sim 10^{-1} \mathrm{JSu} / \mathrm{ml}$ の範囲に阶いて有意の有線関係を認めたが，何れにしても $\mathrm{I}^{131}$ 掑取率を指標とする方法が。次に述べる $\mathrm{I}^{131}$ 放出率を指標とする方法に劣ることに就いては，Bakke et $\mathrm{al}^{329}$. 又は小倉 ${ }^{19}$ 等の成績も同様である。著者は 


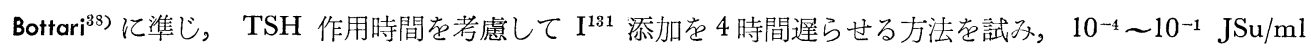
の範囲に有意の直線関係を見出した，しかしこの方法を以つてしても極めて再現性に乏しいことは既述の 如くである. 又，著者は牛甲状腺 slice の $I^{131}$ 摂取能には，作製材料である組織を異にする場合は勿論， 同一組織より作製した slice の間にあつてあ予想以上の変動があるととを指摘したが，このことは Lamberg et $\mathrm{al}^{70)}$. 手の甲状腺に就いて認めており，一般に in vitro に於いて摄取率を指標とする方法が定量性を 欠く主因をなすむのと考えられる。

甲状腺は，その中心部組織に於いて代謝活性が高く，周辺部組織に於いて低いととは, Dempsy ${ }^{45}$ が，コ口 イド染色性の相異より，Knigge ${ }^{65)}$ は濾胞の性状より，Kraiziczek ${ }^{66)}$ がコロイド形成速度より。又 Lamberg $^{67}$, Olin \& Lamberg $^{78)}$ は $\mathrm{P}^{32}$ を用い, Nodler et $\mathrm{al}^{76)}$. は $\mathrm{I}^{131}$ を用いて，又斉藤 ${ }^{26)}$ はSH 作用面から，何れ あこのことを認めている。著者は slice 作製て際しこの点に留意して組織辺緑を避けた中心部からなるべく 一様に slice を作製した。 Hart et $\mathrm{al}^{611}$. は最近これ等組織活性の差異による影響を除くために，牛甲状腺 minces を用い著者の方法と殆んど同じ方法で $\mathrm{I}^{131}$ 摄取率増加を指標とする方法を発表し，1〜10m USPu

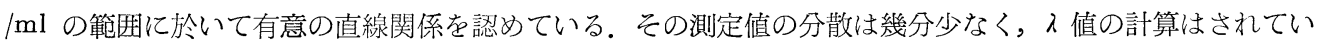
ないが，その検量直線の勾配よりして著者の方法より正確性に於いて優れているようであるが，その季節的 動摇に就いての記載はなく, 又その測定可能範囲よりして実用には供し難いと考学られる. 組織細胞の挫滅 がより大であることが災いしているのではあるまいか.

以上の $\mathrm{I}^{131}$ 摂取率による方法に比較して $\mathrm{I}^{131}$ 放出率による方法が優れているととは，著者の実験成績上

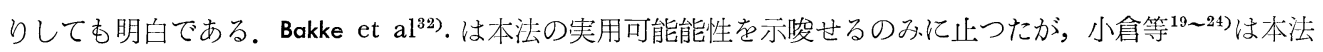
を用いて動物実験及び人血中 TSH 定量を試みている。しかしながらその何れに於いても，本法が一般検定 法として適するか不かに就いての詳細なる検討は未だ行われていない，上つて茲に著者は，斯かる検定法と して満たすべき条件の個々に就いて，Albert ${ }^{29)}$ ，Segaloff ${ }^{86)}$ 及び Lamberg ${ }^{69}$ 亿準じ著者の実験成績を吟味す ると共に， $\mathrm{I}^{131}$ 放出を指標とする本法を既報の諸測定法と比輘検討してみる.

i ）客観性に就いては，本法が放射性同位元素を tracer として使用している以上は，Lamberg ${ }^{699}$ あ指捝 する如く，之を用いない諸方法に較べて主観が入り難いと考えられる.

ii）感度は最む重要なる条件の一つである，何故なら人血中に存在する TSH は極めて微量であり。漉 縮・抽出などの手段に現在未だ適切なる方法がなく ${ }^{2943348) 839}$ ，乙れらの操作は成るべく進けて直接測定する ことが望まれるからであるが，本法に於ける $10^{-5} \mathrm{ml} \mathrm{JSu} / \mathrm{ml}$ の感度は，現在迄に報告された諸方法の中で 最高に属するもので，血中の微量 TSH 測定も可能と思われる.

iii）測定可能範囲は，本法に於いては $10^{-5} \sim 10^{-2} \mathrm{JSu} / \mathrm{ml}$ であり，笑用上支障なき範囲と考えられる。

iv） 検量曲線の勾配化いて，Bakke et $\mathrm{al}^{322}$. の原法又は小倉等 ${ }^{19209}$ の方法によつて著者が追陚した成績 では，表 1，c)，2，A）の如く， slope b は一般に低值に止まり，從つて precision index $\lambda$ は高值を示 し，入值を算出せる何れの測定法よりあ劣るようである（表 3 ）。

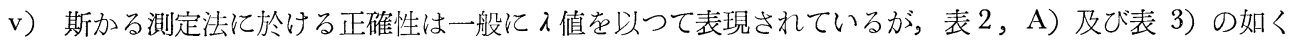

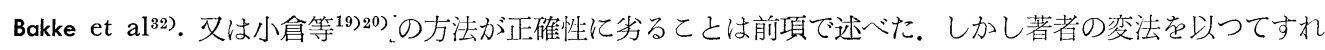
ば，検量曲線の勾配を増大せしめ得るため（図，14），入は低值となり他の諸方法に比較して劣ら正確性 があたらされる（表 $1 . d$ 及び 2 .B）。

vi） 検量曲線に於ける再現性並びにその動摇に就いて論ずるにあたり，既にBakke et $\mathrm{al}^{329}$.及び小倉等 ${ }^{19}$ ${ }^{24)}$ の異なる研究機関に於いて本法が施行されていることは，本法に於ける再現性を既に有力に支持するもの と考えられる。しかしながら年間を通じ Bakke et al ${ }^{322}$. 或は小倉等 ${ }^{1920)}$ の方法に於ける検量曲線は，著考 の追試によると，表 2 . A) の姐く大幅の変動を示し，夏期に於いては勾配が平坦化して有意の検量曲線の 得られぬ場合が多かつた。

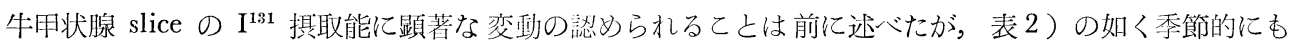

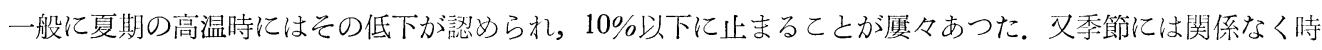


として低値を示し，有意の検量曲線が得られぬととがあつた。 又可成りの $I^{131}$ 揁取率を示したに拘らず， 有意の検量曲線の得引れない場合ああつた，同一組織に於いてもその部分によつて可成りの养異のあること は佨に指摘したが，要するにこれ等变動の主因は，牛の個体差に基ずく甲状腺組織の生化学的性状の差異に あると想像出来る。TSH 亿対する甲状腺の感受性を左右する条件として。, Bergmann et $\mathrm{al}^{377}$. は性別による

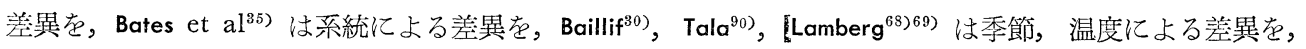
又 Siephans ${ }^{89}$ は栄養状態による差異を述べている。

Lamberg ${ }^{69)}$ は更に，ヒナ $\mathrm{P}^{32}$ 摂取率測定の場合，同系統同腹の初生七ナを用いるべきとしている。著者 は組織の大きさ。均一性，性別，入手の難易，slice 作製の難易を考虑して，通常 4 才去勢牛を用いたが， 指摘される如き性腺剔除による甲状線機能低下は，たとえありとしても交障を来す程のものではなく，又乳 牛の甲状線を用いて雄牛の埸合より良好な成績を得たことああり，採取する組織の選択は充分慎重でなけれ ばならないが。目下その簡単，的確な規準は見当らない。

vii）特異性：甲状腺が特異的に沃度を集積し，TSH が特異的にそれを促進するととには異論なきもの之 考えられる.TSH の沃度集積增進作用に就いて Rawson ${ }^{76)}$ は，甲状腺ホルモン分泌を昂進せしめる結果招 来される二次的の作用之考元，Haimi ${ }^{60)}$ は TSH 投与後 8 時間で沃度集積増加が起り，propylthiouracil 投 与によつて，その抑制されることを見出したが，Levy et $\mathrm{al}^{722}$.は TSH の沃度摂取率増加作用は甲状腺よ りのホルモン分泌促進作用とは独立のものとし，Bakke ${ }^{11}$ は in vitro に於いて， $I^{131}$ 掑取増加は TSH 作用 後 1 時間以内に惹起されると述べている。著者は本法によつて綜合アミノ酸, 各種蛋白，ホルモンに就いて TSH 作用の有無を検したが，性腺刺㦸ホルモン製郕て有意のTSH activity を認めたのみである。東条等 2ə) は TSH 製剤 (Pretiron)に gonadotrophic activity を認めているが，ての問題に就いては稿を改めて 考案したい.

viii）本法か間単迅速に実施出来，経済的である点は他に比類を見ない，著者の变法によれば，検量曲線 の勾配が增加し，従つてその $\lambda$ 值が低下して，ほぼ満足すべき正確性の得られるととは，図14）及び表 1 .

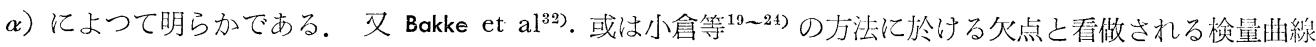
の動摇む，著者の変法を以つてすれば，表 2 ，B）の如く大幅に是正される。しかし slice の $\mathrm{I}^{131}$ 提取能の 低下が見られる夏期に於いては，なお入值の上昇が認められ，時として測定不能であつたが，ての種の測定 法の限界を示すものかどうか，ての点更に今後検討を重ねたい。

総括

in vitro に於ける牛甲状腺 slice の ${ }^{131}$ 掑取立びに放出による TSH 测定法に就いて 基整的㭘味を行つ た絬舆次の知見を得た。

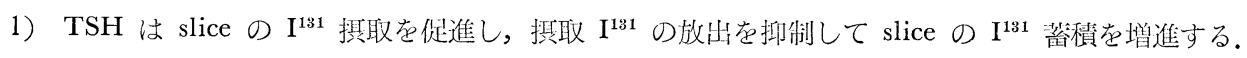

2) 本実験に於いて medium 中に放出される $I^{131}$ は，他の $I^{131}$ 放出法に於ける如き有機化されて $I^{131}$ とは異なり。すべてが無機の $I^{131}$ であることを paper chromatography によつて磪認した。

3） $I^{131}$ 摂取実験に於いて，TSH 負荷と $I^{131}$ 摄取を同時に行う時は，TSH 濃度の対数值と $I^{131}$ 摄取率

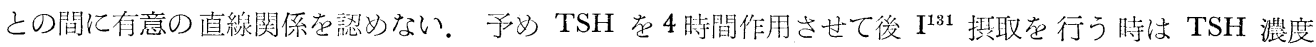
$10^{-1} \sim 10^{-1} \mathrm{JSu} / \mathrm{ml}$ の範羊に於いて推計学上有意の直線部分を得るが，その再垷性は極めて低率であり，從 つて笑用には供し得ない。

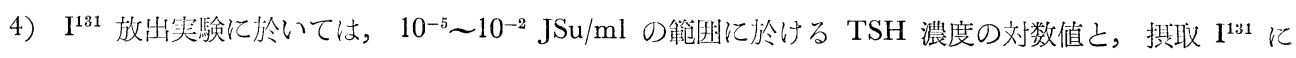
刘与る放出率との間隹接学上有意の直線関係が成立する。

しかしその dose-response には大幅の変動があつて，夏期には贋々有意の関係が認められなかつた。而し て木法に於ける入佰は一般に高值 $(\fallingdotseq 0.68)$ であつた。

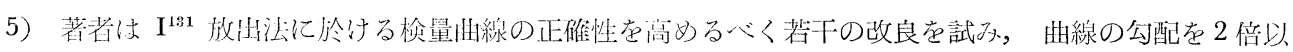
上に增強することによつてほば満足すべき入值（う0.34）を得ることが出来，結果として Bokke et al. 又は 
小倉等の方法の久点を是正し得たと云える.

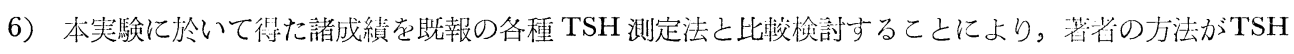
测定法として実用可能であると云う結論在得た。

7）著者の改良法を用いて USP 単位と JS 単位とを比較し。1USP 単位はにほ $10 \mathrm{JS}$ 単位に相当する ことを確認した.

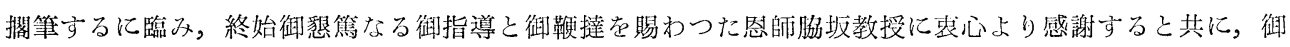
教示御援助を戴いた赤木，鳥塚雨博士に樑謝の意を表する。

\section{文献}

1) 脇坂行一, 河野剛, 山田光雄, 伊藤憲一, 野手信哉, 小林 功, 平井拓造 : 最新医学, $13: 1362$, 响 33. 2) 脇版行一, 河野 剛, 山田光雄, 伊藤憲一, 小林 功, 鳥塚莞爾, 西川 直, 平井拓造,

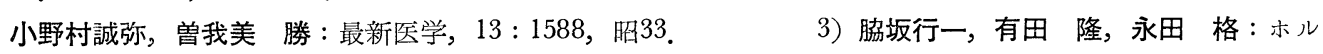

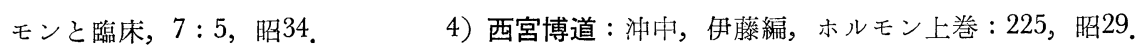

柴田勝博：ホルモンと臨床， $4: 949$, 略 $30 . \quad 6)$ 柴田勝博 : 内分泌のつぞい委員会編，最も新しい ホルモン検查，37，昭31. 7) 西川光夫：内分泌のつぞい委員会編, 最も新しいホルモン検査法, 33, 昭31. 8 ) 鎮目和夫, 入江 実, 飯野史郎 : 最新医学, $12: 23$, 昭 32 . 林 要, 井上 康, 木戸孝治, 置塩郁三：木ルモンと臨床, $6: 225$, 昭 $33 . \quad 10)$ 吉田常雄, 熊原雄 一：綜合臨床，7:762, 昭33. 11 ) 鳥居敏雄, 高橋睄正, 土肥一郎 : 推計学, 2 , 昭 32 .

12）鎮目和夫, 入江 実, 飯野史郎：日内分泌会誌，32：85, 㫿31。 13）宮井 潔, 千頭 隆, 岩 坪治雄, 熊原雄一, 松原美泰: 日内分泌会誌, $33: 126$, 炤 32 14) 置塩郁三, 井上 康, 植田安

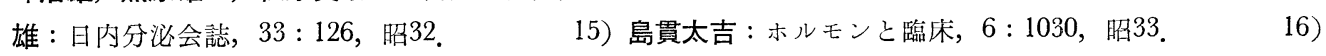
河野 剛, 鳥塚莞爾, 平井拓造, 小林 功, 吉川守之, 小野村誠弥, 坂元良実, 日下部恒輔 : ホルモンと臨 床, 近刊. 17) 入江 実, 鎮目和夫, 石井 淳, 松田邦夫, 長滝重信 : 日内分泌会誌, $35: 220$, 昭34. 18) 野口秋人, 山崎鋭一, 佐藤誠也, 福島郁子: 日内分泌会誌, $35: 219$, 昭 34 .

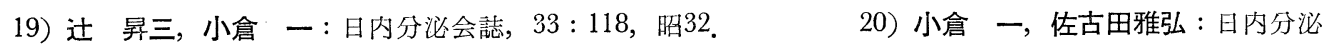
会誌，33:921, 昭32. $21 ＼mathrm{~ 小 倉 ~ 一, ~ 佐 古 田 雅 弘 ~: ~ 日 内 分 泌 会 誌, ~} 34: 274$, 昭 33 . 22) 佐古田雅弘, 小倉 一, 前田浩之: 日内分泌会誌, $34: 1327$, 炤33. 23$)$ 辻 昇三, 小倉一, 佐 古田雅弘, 前田浩之 : 日内分泌会誌, $35: 226$, 昭34. 24$)$ 辻 昇三, 小倉 一, 佐古田雅弘, 小 倉 一, 前田浩之: 日内分泌会誌, $35: 227$, 昭 34.25$)$ 東条伸平, 森下和彦, 矢野一哉: 日内分 泌会誌, $35: 225$, 昭 34 26) 斉藤弘一：北関東医学, $6: 20,1956.27$ 27) Adams, D.D. and Purves, H.D.: Endocrinology, $51: 17,1955.28$ 28) Adams, D.D. and Purves, H.D.: Canad. J. Biochem. \& Physiol., 35 : 993, $1957 . \quad 29)$ Albert, A. : Ann. New York Acad. Sc., 50 : 466, 1949. 30) Baillif, R.N. : Am. J. Anat., $61: 1,1937 . \quad 31)$ Bakke, J.L. and Lawrence, N. : Am. J. Med., 17 $: 116,1954.232)$ Bakke, J.L. and Lawrence, N.: Endocrinology, $58: 531,1956.233)$ Bakke, J.L., Heideman, M.L., Lawrence, N.L. and Wiberg, C. : Endocrinology, $61: 352,1957 . \quad 34)$ Bakke, J.L. and Lawrence, N.L. : J. Clin. Endocrinol. \& Metab., $19: 35,1959 . \quad 35)$ Bates, R.W., Riddle, O. and Lahr, E.L. : Endocrinol., $29: 492,1941 . \quad 36)$ Bates, R.W. and Cornfield, J. : Endocrinology, 60 : 225, 1957. 37) Bergmann, A.J. and Turner, C.W. : Endocrinol., $24: 656,1936 . \quad 38$ ) Bottari, P.M. : Ciba Found. Coll. on Endocrinol., $11: 52,1957 . \quad 39)$ Bottari, P.M. and Donovan, B.T. : J. Physiol., $140: 36,1958 . \quad$ 40) Bottari, P.M. : J. Endocrinol., $17:$ xix, 1958. 41) BrownGrant, K., von Euler, C., Harris, G.W. and Reichlin, S : J. Physiol., 126 : 1, 1954. 42) Brown, J.R. and Dodd, J.M. : Proc. Soc. Endocrinol., 14: xxix, 1956.

43) Collard, H.B., Mills, F.H., Rundle, 
F.F. and Sharpey-Schafer, E.P. : Clin. Sc., 4 : 323, 1940.

44) D'Angelo, S.A. and Gordon, A.S. : Endocrinol., $46: 39,1950$.

45) Dempsy, E.W. : Endocrinol., $34: 27,1944$.

46) De Robertis,

E.D. : J. Clin. Endocrinol., 8 : 956, 1948.

47) Droskin, S. : Endocrinol., 43 : 52, 1948.

48)

Fellinger, K. : Wien. Arch. inn. Med., 29 : 375, 1936.

49) Florsheim, W.H., Moskowitz, N., Schwartz,

J.R. and Morton, M.E. : Endocrinol., 60 : 683, 1957.

50) Freinkel, N. and Ingbar, S.H. : J. Clin. Endocrinol. \& Metab., $15:$ 442, $1955 . \quad$ 51) Frey, H.M. and Albert, A.: Endocrinol., $64: 304,1959$. 52) Gaddum, J.H. : J. Pharm. \& Pharmacol., $6: 345,1953$.

53) Gilliland, I.C. and Strudwick, J.I. :

Clin. Sc., $12: 265,1953$.

54) Goldsmith, R., Herbert, C. and Lutsch, G. : J. Clin. Endocrinol. \& Metab., $18: 367,1958$.

55) Greenspan, F.S., Kriss, J.P., Moses, L.E. and Lew, W. : Endocrinology, $58: 767,1956$.

56) Greenspan, F.S. and Lew, W. : Endocrinol., $64: 160,1959$.

57) Greer,

M.A. : Proc. Soc. Exper. Biol. \& Med., $77: 603,1951 . \quad 58)$ Greer, M.A. : J. Clin. Endocrinol., 12 : 1259, $1952 . \quad 59)$ Gross, J., Leblond, C.P., Franklin, A.E. and Quastel, J.H.: Science, $111: 605$, 1950. 60) Halmi, N.S., Spiritos, Bn., Bogdanove, E.M. and Lipner, H.J. : Endocrinol., 52 : 19, 1953.

61) Hart, T.K., Druet, D. andMack, R.E. : Endocrinol., $64: 857,1959 . \quad 62)$ Hays, E.E. and Steelman,

L.S. : Pincus, G. \& Thiamann, K.V. : The Hormones, III. 206, 1955. より引用. 63) Jefferies, W. M. : J. Glin. Endocrinol., 8 : 596, $1948 . \quad 64)$ Junkmann, K. and Schöller, W. : Klin. Wschr., 11 : 1176, $1932 . \quad 65)$ Knigge, K.M. : Anat. Rce., $127: 75,1957 . \quad 66)$ Kraicziczeck, M. : Z. Zellforsch., $43: 421,1956 . \quad 67)$ Lamberg, B.-A. : Acta Endocrinol., $13: 145,1953 a . \quad 68)$ Lamberg, B.A. : Acta Med. Scandinav. Suppl., 279, 1953b. $\quad 69)$ Lamberg, B.-A. : Acta Endocrinol., $18: 405$, 1955. 70) Lomberg, B.-A., Matovinovic, J. and Stanbury, J.B. : Acta Endocrinol., $29: 33,1958$.

71) Levey, H.A., Cheever, E. and Roberts, S. : Endocrinol., $58: 420,1956 . \quad 72)$ Levy, R.P., Kelly, L. W., Cooper, G.W. and Jefferies, M.W. : J. Glin. Endocrinol. \& Metab., $15:$ 865, $1955 . \quad 73$ ) Loeb, L. and Bassett, R.B. : Proc. Soc. Exper. Biol. \& Med., $26: 830,1929 . \quad 74)$ McCkenzie, J.M. : Endocrinol., $63: 372,1958 . \quad 75)$ Nièpce, B. : Traité du Goiter et du Cretinisme, Paris, 1851. 文献 37）より引用 76) Nodler, N.J., Leblond, C.P. \& Bogoroch, R. : Endocrinol., 54: 154, 1954.

77) Oberbeek, G.A., Fokkens, J., Querido, A., De Visser, J. and Canninga, P. : Acta Endocrinol., 14 : 285, 1953. 78) Olin, C. and Lamberg, B.-A. : Acta Endocrinol., $14: 83,1953 . \quad 79)$ Pincus, G. andighimann, K.V.: The Hormones, I, 661, $1948 . \quad$ 80) Pincus, G. and Thimann, K.V.: The Hormones, II , 301, $1956 . \quad$ 81) Pincus, G. and Thimann, K.V.: The Hormones, III, 206, 1955.

82) Piotti, L.E. : Arch. per Le Sc. Med., $104: 246,1957 . \quad$ 83) Purves, H.D. and Griesbach, W.E. : Brit. J. Exper. Path., $30: 23,1949 . \quad$ 84) Rawson, R.W. : Ann. New York Acad. Sc., $50: 491$, 1949. 85) Roche, J., Jutisz, M., Lissitzky, S. and Michel, R. : Biochem. et Biophy. Acta, $7: 257$, 1951. 86) Segaloff, A. : Ciba Found. Coll. Endocrinol., $5: 1,1953 . \quad 87)$ Smith, P.E. and Smith, I.P. : J. Metab. Res., $43: 267,1922 . \quad$ 88) Sonenberg,M. : Vitamines and Hormones, $16: 205$, 1958. 89) Stephans, D.J.: Endocrinol., $26: 485,1940 . \quad 90)$ Tala, P. : Acta Endocrinol. Smppl., 9, $1952 . \quad 91)$ Tala, P. : Endocrinol., $53: 474,1953 . \quad 92)$ Taurog, A., Chackoff, I.L. and Feller, D.D. : J.B.C., 171 : 189, 1947. 


\title{
甲状腺刺㦸ホルモン $(\mathrm{TSH})$ そ関する臨床的並びに実験的研究
}

\author{
第 2 報 人 血中 TSH $の$ 測 定
}

京都大学医学部内科笎一講座 (指導 脇坂教授)

永田格

\section{緒 言}

視床下部一下垂体一甲状腺と云う一つの機能的単位の成立するととは今日ほぼ異諭のないところである.

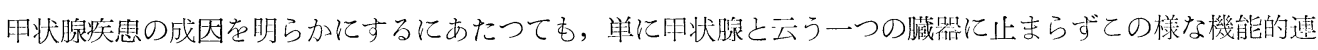
関を対象とする必要があることは云う迄もないが，その複雑な機權は今日なお統一的に解朋されていない． 而してその研究の進展を姉げる原因の一つは，人体液中の甲状腺刺㦸ホルモン (TSH) を正確に測定する方 法が未だないととであると云つてさしつかえない.

TSH 測定法の進歩と共に人尿中及び人血中の TSH 量に関する報告は相継いでいる（表 1 及び 2 ）しか し今日までに試用された測定方法の多数に較べるとはるか少数に止まり，且つその煩雑な测定法の故に多数 例に就いての記載は少なく，加之各報告者の測定偡の間には相当の差異が認められる.

しかしながら正常人尿中，或は血中に TSH の存在することは確笑となつた。人尿中に含まれる TSH 量 は血中量よりもはるかに微量であるため大規模な抽出操作を必要とする。血中の TSH 量屯微量であるた

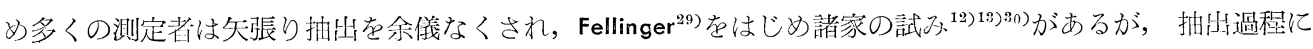

節 1 表人尿 (1 日量) 中の T S H量 ( J S 単位)

\begin{tabular}{|c|c|c|c|c|c|c|}
\hline 報 告 者 & 測 定 法 & 抽出法 & 正常人 & $\begin{array}{c}\text { 甲状 腺 } \\
\text { 機能低下症 }\end{array}$ & $\begin{array}{c}\text { 甲 状 腺 } \\
\text { 機能充進症 }\end{array}$ & 眼 突 症 \\
\hline $\begin{array}{l}\text { Hertz \& Oastler }{ }^{\prime} \\
(1936)\end{array}$ & $\begin{array}{l}\text { 下垂体摘出亏ッ } \\
\text { 辛状腺濾胞細 } \\
\text { 胞組織像 }\end{array}$ & アセトン抽出 & $(-)$ & $(t)$ & $(-)$ & \\
\hline$\underset{\text { Rawson } \& \operatorname{Starr}^{2)}}{(1938)}$ & \begin{tabular}{|l|}
$\begin{array}{l}\text { 海犋甲状腺濾胞 } \\
\text { 上皮高 }\end{array}$ \\
\end{tabular} & アセトン沈澱 & $(+)$ & $(+)$ & $(-)$ & \\
\hline $\begin{array}{l}\text { Jones } \\
(1939)\end{array}$ & $\begin{array}{l}\text { 七ナ甲状腺滤胞 } \\
\text { 細胞高 }\end{array}$ & アセトン抽出 & $(-)$ & $(+)$ & $(-)$ & \\
\hline $\begin{array}{c}\text { Savoie }{ }^{4)} \\
(1952)\end{array}$ & "I & " & $\begin{array}{l}7 \text { 例 }(+) \\
10 \text { 例 }(-)\end{array}$ & $\begin{array}{l}4 \text { 例 }(+) \\
2 \text { 例 }(-)\end{array}$ & $\begin{array}{r}\text { 未治療 } 4 \text { 例 } \\
\text { 既治療 } 7 \text { 例 } \\
(+)\end{array}$ & \\
\hline $\begin{array}{l}\text { Crook \& Mathe - } \\
\text { ws }^{5)}(1953)\end{array}$ & "I & 超遠心沈澱 & & & & $\begin{array}{l}(+) \\
\text { 尿 } 15 \mathrm{ml}\end{array}$ \\
\hline $\begin{array}{l}\text { Bloche-Michel \& } \\
\text { Henry' }^{6} \quad(1955)\end{array}$ & $\begin{array}{l}\text { サイロキシン投 } \\
\text { 与海憬甲状腺 } \\
\text { I }^{131} \text { 摂取 }\end{array}$ & $\begin{array}{l}\text { アルコール } \\
\text { 沈 澱 }\end{array}$ & $\begin{array}{l}3 \text { 例 } \\
0 \sim 1 \mathrm{mJS}\end{array}$ & $\begin{array}{l}1 \text { 例 } 10 \mathrm{mJS} \\
\text { Simmonds' } \\
\sigma 1 \text { 例结 } 0 .\end{array}$ & $\begin{array}{l}7 \text { 例 } \\
0 \sim 15 \mathrm{~m} J S\end{array}$ & $\begin{array}{l}4 \text { 例 } \\
0 \sim 24 \mathrm{~m} \mathrm{JS}\end{array}$ \\
\hline $\begin{array}{l}\text { Bloche-Michel \& } \\
\text { Henry }^{6} \quad(1955)\end{array}$ & $\mid \begin{array}{l}\exists \text { ヨートカゼイン投 } \\
\text { 与世放ずみ状 } \\
\text { 腺 } \mathbf{I}^{131} \text { 摂取率 }\end{array}$ & 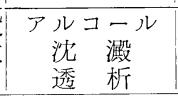 & $\begin{array}{l}4 \text { 例 } \\
2.5 \sim 4.5 \mathrm{~m} \mathrm{JS}\end{array}$ & $\begin{array}{l}1 \text { 例 } 32.5 \mathrm{mJS}: \\
\text { 状腺未投与 } \\
\text { 後 } 13.5 \mathrm{mJS}\end{array}$ & \begin{tabular}{|r|}
4 例 \\
$2.5 \sim 13.5$ \\
$\mathrm{mJS}$ \\
\end{tabular} & $\begin{array}{l}5 \text { 例 } \\
0 \sim 17.5 \mathrm{mJS}\end{array}$ \\
\hline $\begin{array}{l}\text { Kriss" \& Greens - } \\
\operatorname{pan}^{7)^{-}}(1954)\end{array}$ & 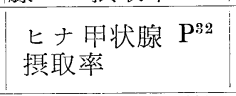 & $\begin{array}{l}\text { アルコール } \\
\text { 沈溊 } \\
\text { 超遠心沈澱 }\end{array}$ & $10 \sim 250 \mathrm{mJS}$ & & & \\
\hline $\begin{array}{c}\text { Adams } \underset{\text { 9) }}{\&} \text { Purves } \\
(1956)\end{array}$ & $\begin{array}{l}\text { 海獏甲状腺 } \mathrm{I}^{131} \\
\text { 放出率 (サイロ } \\
\text { キシン投与) }\end{array}$ & $\begin{array}{l}\text { アルコール } \\
\text { 沈 漋 }\end{array}$ & & $\begin{array}{l}1 \text { 例 } \\
25 \mathrm{~m} \text { JS } \\
\end{array}$ & & \\
\hline
\end{tabular}


第 2 表（その 1 ）人血中 $\mathrm{T} \mathrm{SH}$ の測定 ミリ $\mathrm{J} \mathrm{S}$ 単位 $/ \mathrm{ml}$ ：血清又は血漿

\begin{tabular}{|c|c|c|c|c|c|c|}
\hline 報 告 者 & 方 法 & $\begin{array}{l}\text { 用状腺機能 } \\
\text { 正常 者 }\end{array}$ & $\begin{array}{l}\text { 甲状腺機能 } \\
\text { 低 下 者 }\end{array}$ & $\begin{array}{l}\text { 甲状腺機能 } \\
\text { 克 進 者 }\end{array}$ & 眼球突出者 & \\
\hline $\begin{array}{l}\text { De Robertis }{ }^{12)} \\
(1948)\end{array}$ & $\begin{array}{c}\text { 海猽濾胞上 } \\
\text { 皮内 } \\
\text { コロイド滴 }\end{array}$ & $2.5 \sim 5(3$ 例 $)$ & $\begin{array}{c}\text { 正常以下 }(2 \text { 例 }) \\
500 \text { 以上 } 1 \text { 例 }) \\
30 \text { (1 例) }\end{array}$ & $\begin{array}{l}50 \text { 以上(2例) } \\
4 \text { 例怔常以市. } \\
\text { 奖腺切除で正 } \\
\text { 常化: thiouracil } \\
\text { 正常化. }\end{array}$ & \begin{tabular}{|}
50 以上 $(2$ 例) : \\
1 例は䤚状腺末 \\
投与で正常化.
\end{tabular} & $\begin{array}{l}\text { Fellinger } \\
\text { 氏法で抽出 } \\
\text { 血液 } 1 \mathrm{ml}\end{array}$ \\
\hline $\begin{array}{l}\text { Del Conte }{ }^{13)} \\
\text { (1949) }\end{array}$ & "1 & $0.5 \sim 50$ & & $\begin{array}{l}\text { 非眼突群は } 0.1 \\
\text { 以尗状腺切 } \\
\text { 除で正平化. } \\
\text { thiouracil で } \\
\text { 正常化. }\end{array}$ & \begin{tabular}{|l|} 
眼突群は異常高 \\
値: $T_{4}$ 投正 \\
常. 化
\end{tabular} & $\begin{array}{l}\text { Fellinger } \\
\text { 氏法で抽出 } \\
\text { 血液 } 1 \mathrm{ml}\end{array}$ \\
\hline $\begin{array}{l}\text { Purves \& } \\
\text { Griesbach }{ }^{14)} \\
(1949)\end{array}$ & $\begin{array}{c}\mathrm{T}_{4} \text { 投与 } \\
\text { 海猽上皮高 }\end{array}$ & 測定不能 & 正常以上( 5 例) & $\begin{array}{l}\text { 測定不能(22例) } \\
\text { 治療後19例は上 } \\
\text { 㚖 }\end{array}$ & $\begin{array}{l}37 \text { 例に正常以上 } \\
\text { の高値 }\end{array}$ & $\begin{array}{l}\text { Fellinger } \\
\text { 氏法で抽出 } \\
\text { 血液 } 1 \mathrm{ml} \\
\end{array}$ \\
\hline $\begin{array}{l}\text { D'Angelo et al. }{ }^{15)} \\
\text { (1951) }\end{array}$ & 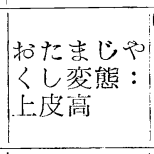 & $\begin{array}{l}0 \sim 1.0 \text { (10例) } \\
3 \sim 5 \text { (末端肥大 } \\
\text { 症 } 3 \text { 例) } \\
0 \text { (Simmonds' } \\
3 \text { (例) }\end{array}$ & $\begin{array}{l}0 \sim 5 \text { (10例) } \\
\text { 甲状腺末投与で } \\
\text { 一定の変化なし }\end{array}$ & $0 \sim 2$ (10例) & $\mid \begin{array}{l}0 \sim 5(8 \text { 例 }): 2 \\
\text { 例は甲状腺末投 } \\
\text { 与で増加 }\end{array}$ & \\
\hline$\underset{(1952)}{\text { Simkin et al. }{ }^{16)}}$ & 'I & $\begin{array}{c}\text { 测定不能(11例) } \\
\text { 湘定不能 } \\
\text { (Simmonds') } \\
2 \text { 例 }\end{array}$ & \begin{tabular}{|c|} 
正常以上 $(8$ 例 $)$ \\
状脉末 \\
少量で増加 \\
" \\
大量で減少
\end{tabular} & 测定不能 & & \\
\hline $\begin{array}{l}\text { Di George et al. }{ }^{17)} \\
(1955)\end{array}$ & "I & 測定不能 & $\begin{array}{l}\text { 測定不能 } \\
\text { 归状腺末で増加 }\end{array}$ & & & \\
\hline $\begin{array}{l}\text { DiGeorge et al. }{ }^{19)} \\
\text { (1957) }\end{array}$ & "I & $\begin{array}{l}0 \sim 10 \text { (平均 } 4) \\
6.0 \text { (小监) } \\
8.0 \text { (小昌) }\end{array}$ & $\begin{array}{l}2.0 \text { (クレチ } \\
\text { ン1 例) }\end{array}$ & & & \\
\hline $\begin{array}{l}\text { Gilliland \& Str- } \\
\text { udwick }^{19)} \\
(1956)\end{array}$ & $\begin{array}{c}\mathrm{T}_{4} \text { 投与ひ } \\
\text { な } \\
\mathrm{I}^{131} \text { 放出率 }\end{array}$ & $\begin{array}{c}0 \text { - } 1.65(5 \text { 例 }) \\
\text { 测定不能 } \\
\text { (Simmcnds') } \\
3 \text { 例 }\end{array}$ & $\begin{array}{r}0 \sim 28.19 \\
(14 \text { 例) }\end{array}$ & $\begin{array}{r}0 \sim 4.72 \\
\quad(5 \text { 例 })\end{array}$ & $\mid \begin{array}{c}10.18 \text { (12例) } \\
\text { 眼突のみを件う } \\
3 \text { 例では } \\
0 \sim 0.82\end{array}$ & \\
\hline $\begin{array}{l}\text { Adams \& Purves } \\
\quad(1956)\end{array}$ & $\begin{array}{c}\mathrm{T}_{4} \text { 投与海 } \\
\text { 埧 } \\
\mathrm{I}^{131} \text { 放出率 }\end{array}$ & & & & $\begin{array}{l}\text { 強陽性の反応を } \\
\text { 示した } 1 \text { 例は } \\
\mathrm{T}_{4} \text { 投与後も不 } \\
\text { 変 }\end{array}$ & \\
\hline
\end{tabular}

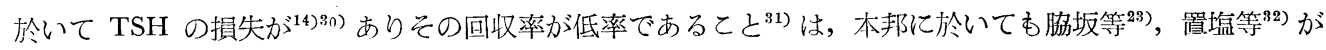
跃に実証している。

さきに著考 39 は in vitro に於ける牛甲状腺 slice の $\mathrm{I}^{131}$ 摂取並びに放出による TSH 測定法に就いて 基礎的検討を行い，TSH による $\mathrm{I}^{131}$ 放出率抑制を指標とする方法に実用の可能性があることを指摘した. 今回著考の測定万法を用いて正常人並びに甲状腺ほか各種内分泌疾患及びその他の疾患患者の血清 TSH 聂 を测定し，それ等の臨床症状及び検查諸成續との相互関係に就いて㭘討を行つたので茲に報告する。

\section{実験材料並びに方法}

\section{1) $\mathrm{TSH}$ 測定方法}

著者の湘定汒の大要に就いては既に詳述した ${ }^{33)}$ 。即ち新鮮な牛甲状腺 slice を incubate して $I^{131}$ を先 ず掑取せしめ，次いで $1^{131}$ を含ま如 medium 中に放出させる時， medium に添加した TSH 濃度の対数 做が一定值が一定区間に於いてその $I^{131}$ 放出に及に゙す抑制效果と直線関係にあることを利用したあのであ る。著者は原法の検量曲線の勾配を増大せしめるために slice の重量を $100 \mathrm{mg}$ とし， $\mathrm{I}^{131}$ 掑取時は slice $100 \mathrm{mg}$ に対し $4 \mathrm{ml}$ の medium で， $\mathrm{I}^{131}$ 放出時は $3 \mathrm{ml}$ の medium で incubate した. 而して $\mathrm{I}^{131}$ 提取 後はこの medium $1 \mathrm{ml}$ に就いて， ${ }^{131}$ 放持後はその $2 \mathrm{ml}$ に就いて 
第 2 表 (その 2 ) 人血中 $\mathrm{T} \mathrm{SH}$ の測定 そり $\mathrm{J} \mathrm{S}$ 単位 $/ \mathrm{ml}$ ：血清又心血漿

\begin{tabular}{|c|c|c|c|c|c|c|}
\hline 報 告 者 & 方 法 & $\begin{array}{l}\text { 甲状腺機能 } \\
\text { 正常 者 }\end{array}$ & $\begin{array}{l}\text { 甲状腺機能 } \\
\text { 低 下者 }\end{array}$ & $\begin{array}{l}\text { 甲状腺機能 } \\
\text { 几進 者 }\end{array}$ & 眼球突出者 & \\
\hline $\begin{array}{l}\text { Adams }^{20)} \\
(1958)\end{array}$ & $\begin{array}{l}\mathrm{T}_{4} \text { 投与海 } \\
\text { 猽 } \\
\mathrm{I}^{131} \text { 放分率 }\end{array}$ & 测定不能 (4 例) & $\mid \begin{array}{l}10 \sim 25(4 \text { 例 }): \\
2 \text { 例は } \mathrm{T}_{4} \text { 掞与 } \\
\text { で減少 }\end{array}$ & $\begin{array}{l}\text { 測定不能( } 5 \text { 例 }) \\
\text { MTU 投与寺 } 2 \\
\text { 例は4.0〜 } 7.5 \text { 亿 } \\
\text { 上昇 }\end{array}$ & & 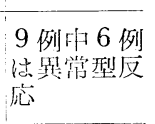 \\
\hline $\begin{array}{l}\text { McKenzie }^{21)} \\
\text { (1958) }\end{array}$ & $\begin{array}{c}\mathrm{T}_{4} \text { 投与 } \\
\text { 日小导み } \\
\mathrm{I}^{131} \text { 放出率 }\end{array}$ & 2 (推定) & 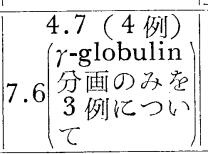 & & & \\
\hline $\begin{array}{l}\text { Bottari }^{22)} \\
(1958)\end{array}$ & $\mid \begin{array}{l}\text { 海憬 } \\
\mathrm{I}^{131} \\
\text { (in } \\
\text { in }\end{array}$ & $\left|\begin{array}{|}2.0 \sim 2.5 \text { (20才 } \\
\sim 60 \text { 才男 } 120 \text { 例) } \\
3.7 \text { (閉経前婦 } \\
\text { 人) } 0.5 \text { (老人) }\end{array}\right|$ & $\begin{array}{l}20 \text { ～80 } \\
\text { 治療後正常化 }\end{array}$ & \begin{tabular}{|l}
1.0 前後 \\
又心正常傎 \\
$(2.2$ 前後 $)$
\end{tabular} & & $\begin{array}{l}\text { 正常平均は } \\
2.2 \mathrm{~m} \mathrm{JS} / \\
\mathrm{ml} 2.2\end{array}$ \\
\hline $\begin{array}{l}\text { 脇坂・河野他 }^{23)} \\
(1958)\end{array}$ & $\begin{array}{c}\text { ヒナ } \mathrm{P}^{32} \\
\text { 摂取率 }\end{array}$ & 測定不能 (1 例) & $\begin{array}{c}16.9 \text { ( } 1 \text { 例 }) \\
\text { 測定不能 }(1 \text { 例 })\end{array}$ & $\mid \begin{array}{l}14.4 \text { (卿突虎伴 } \\
51 \text { 例) } \\
24.8 \text { (归状腺切 } \\
\text { 除後の } 1 \text { 例) } \\
\text { 測定不能 ( } 2 \text { 例) }\end{array}$ & & $\begin{array}{l}\text { Fellinger } \\
\text { 氏法にて抽 } \\
\text { 出 }\end{array}$ \\
\hline $\begin{array}{l}\text { 小會・佐古田 } \\
\text { (1958) }\end{array}$ & \begin{tabular}{|l|} 
in vitro \\
牛田状腺 \\
Slice I I \\
放出率
\end{tabular} & 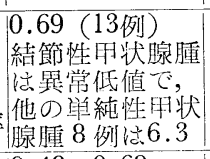 & $4.12(5$ 例 $)$ & $\left|\begin{array}{l}\text { Basedow } 16 \text { 例は } \\
0.01 \text { 前後群 } \\
3 \text { 前後群に } 2 \text { 分 } \\
\text { された }\end{array}\right|$ & & \\
\hline $\begin{array}{l}\text { 河里 • 鳥塚他 }^{25)} \\
(1959)\end{array}$ & 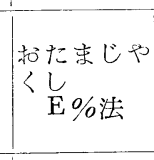 & $\begin{array}{l}0.48 \sim 0.69 \\
(3 \text { 例) } \\
0.51 \sim 1.20 \text { (盟 } \\
\text { 純性甲状腺湟 } 5 \\
\text { 例) }\end{array}$ & {$\left[\begin{array}{l}1.0 \text { (タレチン } \\
1 \text { 例) } \\
0 \sim 0.29 \text { (下重 } \\
\text { 体性 侏儒症 } \\
\text { 例) }\end{array}\right.$} & 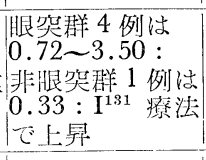 & & \\
\hline $\begin{array}{l}\text { 野口・他 } \\
(1959)\end{array}$ & $\begin{array}{l}\text { ヒナ } \mathrm{P}^{32} \\
\text { 摂取率 }\end{array}$ & 0.5 以下 & & & & \\
\hline $\begin{array}{l}\text { 入江・鎮目 }{ }^{27)} \\
(1959)\end{array}$ & $\begin{array}{l}\text { 廿日水ずみ } \\
\mathrm{T}_{4} \text { 投与後 } \\
\mathrm{I}^{131} \text { 放出摔 }\end{array}$ & 測定不能 (3 例) & 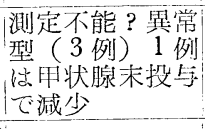 & $\begin{array}{l}4 \text { 例中 } 3 \text { 例に } \\
\text { 鼠常型区応 }\end{array}$ & & \\
\hline $\begin{array}{c}\text { 帠 }{ }^{\left.- \text {貫 }^{28}\right)} \\
(1958)\end{array}$ & $\begin{array}{l}\text { ヒナP } \mathrm{P}^{32} \\
\text { 摂取率 }\end{array}$ & $\begin{array}{l}\text { 男子 } 6 \text { 例《測定 } \\
\text { 不能 (10以下) } \\
\text { 女子 } 33 \text { 例は平均 } \\
0.27,4 \text { 才 9才 } \\
\text { ○女子 } 5 \text { 例は平 } \\
\text { 均 } 3.16\end{array}$ & & & & $\begin{array}{l}\text { Fellinger } \\
\text { 氏法にて抽 } \\
\text { 出 }\end{array}$ \\
\hline
\end{tabular}

TSH 濃度 $10^{-4}$ 及び $10^{-3} \mathrm{JS} \mathrm{u} / \mathrm{ml}$ の 2 点をとの都度 Standard にとり，血清又は血漿を medium で 約10倍に稀釈したものを被験 medium として，各点には slice 4 〜 万を充当し，Gaddum ${ }^{34)}$ に做つて“ 3 点法”で行い，入值を算出した．Gaddum ${ }^{34)}$ にれば推計学的冠地よりして“ 4 点法”を理想とするが，て の方法では未知血清む 2 種の異なる 濃度群に調製しなければならない. 木法の測定可能笘囲 $\left(10^{-5} \sim 10^{-2}\right.$ $\mathrm{JSu} / \mathrm{ml})$ 及び血清の TSH 濃度 $\left(10^{-3} \mathrm{JSu} / \mathrm{ml}\right.$ 前後と推定される) よりして本法では slice 1 ケにつき被験 血清は少なくとす $0.3 \mathrm{ml}$ を必要とする。而して木法の正確性よりして被験 medium の間の濃度差は问成 り大きくしなければならないので，低濃度群に0.3 $\mathrm{ml}$ 血清を用いるとすれば高濃度群には更にその数倍の 血清を要することになり，1回の測定に大量の採血が必要となつて车用に適せず，よつて以下“3点法”で 施行した.

Standard そは Schering 製 “Pretiron”を使用した。 以下すべて JS 単位で表わし，文献上の IUSP 及

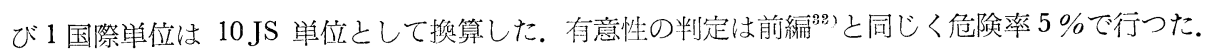

\section{2) 対象とした症例}

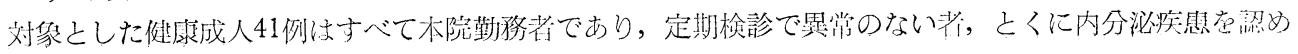

$$
\text { 第35卷 筑 } 11 \text { 率 }
$$


ない者を択らび，うち女子10例については基礎代謝率（BMR），血清蛋白結合ヨード（PBI）及び甲状腺 $\mathrm{I}^{131}$ 摂取率 (24時間值) を測定して甲状腺機能正常なるととを磪めた。各種疾㭧症例に就いては本院入院患 者を対象とし，甲状腺疾思は一部少数の外来患者より臨床所見及び検查成績から診断の確定したすののみを 撰んだ。脳下垂体，副筹その他の内分泌疾患の大多数は既に三宅 ${ }^{99}$ により報告された症例である。

これ等の患者は殆んどが測定 $1 \sim 2$ 週前から一定の摂取ヨード制限下に於いては取扱われ，外来息者にあ つてあ同様であるが，実際に尿中排泄ヨード量の測定されたのは僅少に止まる．而しててれ等の患者の殆ん ぞが未治療者であるが，既治療者，治療中であつた者には少くとも1 カ月治療を中止してから測定した，無 論 $I^{131}$ 療法之か長期持続効果を示すホルモン療法等を受けた者は対象から除外している.

採血は早朝空腹時を原則とし血清又はへパリン加血漿を直ちに分離して承室に保存して測定に供し，当日 そ測定出来ない場合は谏結保存して 3 日以内に測定するようにした。

\section{実 験 成 績}

\section{I ） 著者の方法の臨床応用に関する吟味}

1）著者の方法の特異性

本法に於いて牛甲状腺 slice の $\mathrm{I}^{131}$ 放出抑制が果して TSH の特異的作用によるあのか否かを検するた めに各種のホルモン及びその他の制剂を medium 亿添加してその TSH 活性を比較し，人血清 $\gamma$-globulin， ACTH (Schering), Anteron 及び Primogonyl に僅かながら TSH 活性を認めた。 ての袢 Anteron (Schering 製妊馬血清性性腺刺战ホル モン) 及び Primogonyl (Schering 製 䋐毛性性腺刺战 ホルモン) は有意の TSH 效果走した. cortisone, hydrocortisone acetate は何れも却つて $\mathbf{I}^{131}$ 放出を増加せしð，TSH 作用とは逆 方向の作用を示し，結果として甲状腺 の $\mathrm{I}^{131}$ 集積能を直接抑制する效果を 示した（表3).

\section{2）血清及び血漿に於ける TSH 量}

同一人より採取した血清及び血獎 （ヘパリン加）に就いて TSH 活性の 差異を検するために slice 13ケを各々 に充当して検討し危険率 $1 \%$ 亿於いて 有意の差を認めなかつた。

3）著者の方法に於ける（添加） TSH 回収実験

Table 3 TSH-activities of some preparations in $\mathrm{I}^{131}$-release of surviving thyroid slices.

\begin{tabular}{|c|c|}
\hline Compounds tested & $\begin{array}{l}\text { TSH activity } \\
\text { found }\end{array}$ \\
\hline Moriamin S & 0 \\
\hline Human Albumin & 0 \\
\hline Human $\gamma$-Globulin & $0.02 \mathrm{~m}$ J.S.u \\
\hline 1-Thyroxine & 0 \\
\hline 1-3.5.3' : Triiodothyronine & 0 \\
\hline Cortisone acetate & 0 \\
\hline Hydrocortisone acetate & 0 \\
\hline ACTH “Schering" & $0.13 \mathrm{~m}$ J.S.u \\
\hline Gonadotropin “Anteron" Schering 100u. & $1.76 \mathrm{~mJ} . \mathrm{S} . \mathrm{u}$ \\
\hline Gonadotropin "Primogonyl" Schering & $1.91 \mathrm{~m} 4 . \mathrm{S} . \mathrm{u}$ \\
\hline
\end{tabular}

Table 4 A test of recovery of added TSH-preparation to serum

\begin{tabular}{|c|c|c|c|}
\hline standard \& unknown sample & $\%$ release & measured dose & $\%$ recovery \\
\hline standard $\quad 10^{-4} \mathrm{JSu} / \mathrm{ml}$ & $92.0 \pm 5.2$ & $1.0 \times 10^{-4} \mathrm{JSu} / \mathrm{ml}$ & \\
\hline standard $10^{-8} \quad \prime \prime$ & $74.4 \pm 4.6$ & $10.0 \times 10^{-4} \quad / 1$ & \\
\hline unknown serum & $89.8 \pm 3.4$ & $1.4 \times 10^{-4}$ & \\
\hline standard $10^{-3}+$ unknown serum & $76.6 \pm 4.4$ & $9.8 \times 10^{-4}$ & 85.9 \\
\hline standard $10^{-4}+$ unknown serum & $87.6 \pm 4.3$ & $1.5 \times 10^{-4}$ & 62.5 \\
\hline
\end{tabular}


人血清を用いて通常の如く測定すると共に，別に既知量の TSH $\left(10^{-4}\right.$ 及び $10^{\sim 3} \mathrm{JS}$ 単位) を同一血清に 添加してその回収率を見るに，表4）に示す如く平均 $74 \%$ の回収率を得た。

II) 臨床 成 績

1) 健常成人に於ける血清 TSH 量

健康成人男子 20 例の血清 TSH は 図 1，2）に示す如くであり, 平均 $1.59 \pm 1.28$ (standard deviation) $\mathrm{mJSu} / \mathrm{ml}$ である。 その裡 50 才以下の 15 例に於ける平均は $1.82 \pm 1.38 \mathrm{mJSu} / \mathrm{ml}, 50$ 才以上の 5 例に於いて は $0.89 \pm 0.54 \mathrm{mJSu} / \mathrm{ml}$ であり若干低值を認めた。同女子 21 例は何れあ 20 才より40才迄の考で $1.91 \pm 1.49$ $\mathrm{mJSu} / \mathrm{ml}$ の平均を示し男子例よりやや高傎であるが有意の差は認められなかつた。

健康成人 5 例に於ける血清 TSH 量の季節的変動は図 $2 ， \mathrm{~B})$ に示される。その平均値は 1 月に比較し て7月には若下低下を示した。

Fig. 1 Serum TSH levels in normal subjects and patients with various disorders

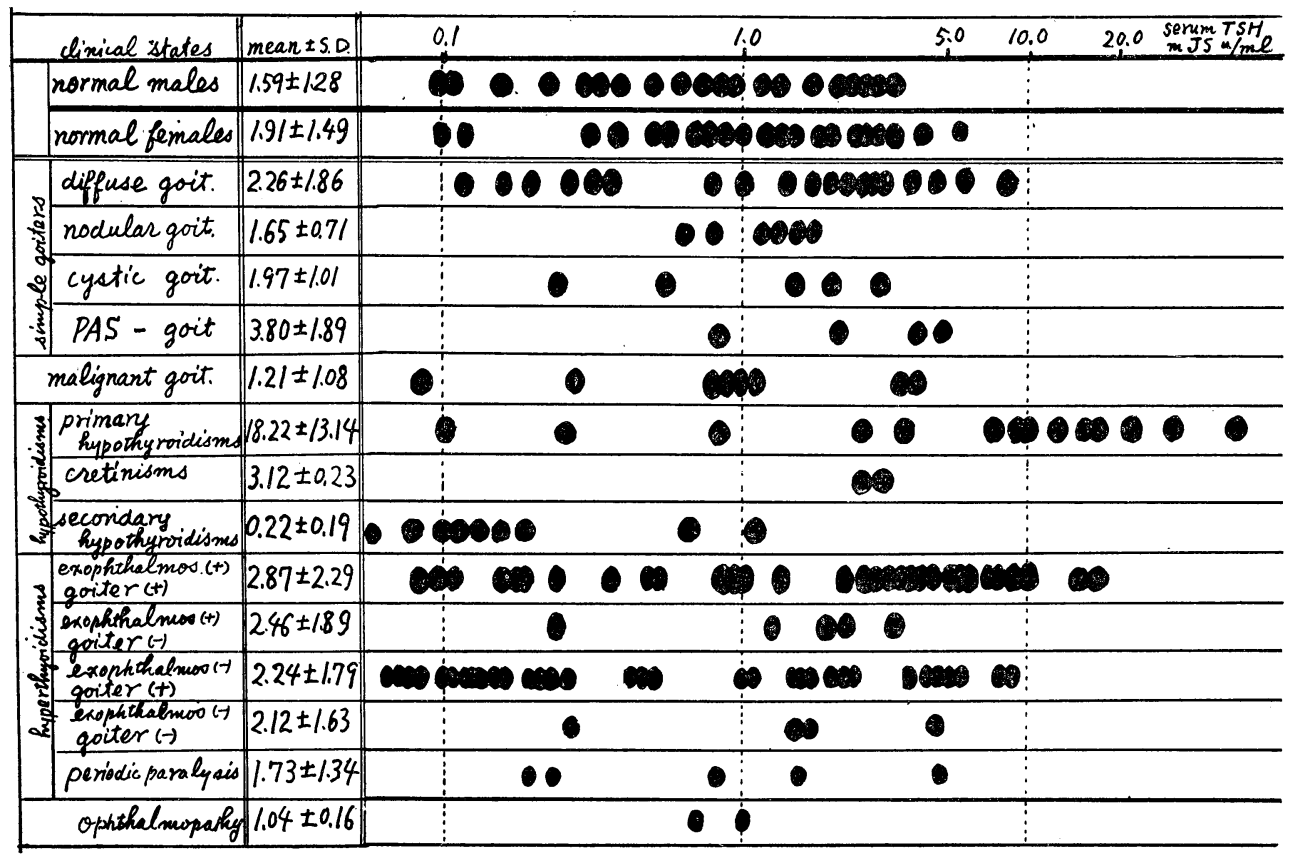

2）各種甲状腺疾患に於ける血清 TSH 量（図 1)

単純性甲状腺腫の裡，19例のびまん性甲状腺腫例は大多数が20〜30才台の女子であるが平均 $2.26 \pm 1.86 \mathrm{~m}$

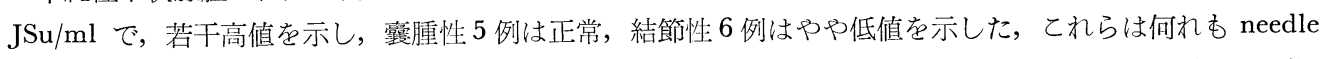
biopsy で組織学的に決定されたものである. PAS を 2 年以上にわたり内服したため甲状腺腫を来した（但 し軽度）と推定される軽症肺結核患者 4 例は高值 $(3.80 \pm 1.89 \mathrm{mJSu} / \mathrm{ml})$ を示した.

これら単純性甲状腺腫に於ける血清 TSH 量と PBI 值は図 3 ）の如く逆相関を示したが，著者が検索 した例数では推計学上の有意性は認められなかつた。

16例の原発性甲状腺機能低下症の裡, 粘液水腫と診断されたのは 4 例, 侏儒症とされたのは 2 例, 他は TSH 試験その他の検查により明らかにされたあのであるが，その裡 9 例の血清 TSH 量は明らかに異常高 值を示した.

下垂体性と判断された甲状腺機能低下症 9 例は何れも汎下重体機能低下を涩めなかつた症例であり，血清 
TSH 量は異常低值であつた。

8 例の悪性甲状腺腫の裡 7 例は50才以 上で，1例だけが23才女子であつた。 こ の 1 例を含む 2 例在除き，他仗正常，或 は低值を示した。この 2 例のうち 1 例 ( 23才女子）は $\mathrm{I}^{131} 3 \mathrm{ml}$ の投与受けて後 2 力月で血清 TSH 亿有意の增加を認 め(図15,D)，レ線照射 (線量不詳) : 受 けた他の 1 例（50才男子）は増加の傾问 を示した。甲状腺切除術を受けた 4 例は 術後10日に於いて血中 TSH 量は一定の 傾问を示さなかつた（図15,D)

3) 甲状腺機能六進症に於ける血清 TSH 量 (図 1)

著者が対象とした73例に於いては 0.1 $\mathrm{mJSu} / \mathrm{ml}$ 以下より $10 \mathrm{mJSu} / \mathrm{ml}$ 以上に わたる広範な分散が認められた。乙れ等 を甲状腺腫の有無，或は腿球突出の有無 によつて 4 群に分類すると，眼突，甲状 脉腫共に備えた群は最高の平均值を示し， 以下眼突のみを備えた群，甲状腺腫 のみ認められる群，眼突・甲状腺腫 共に外見上見出し難い群の順序に血 清 TSH 量の平均は低值を示すが, 平均值に於いて何れも正常人より多 少とあ高值であるととが認められた 。しかし推計学上有意の差とは云え ない，更にこれら73例を甲状腺 $\mathrm{I}^{131}$ 摄取率曲線の型によつて分類 ${ }^{35}$ す れ 价表5）の如く，全体として上昇型， 下降型は相半ばしているが，眼症状 を伴う群に下降型が明らかに多く認 められ，血清 TSH level 屯下降群 には推計学上の有意性は認められな いが，上昇型群に比較して可成りの 高值が認められた。

周期性四肢麻脾の 5 例は，1例を除きすべて甲状腺機能九進を示したがこの血清 TSH 量はほぼ正常範掤 にあつた。

眼球突出のみを唯一の症状とし甲状腺機能は正常であつた 2 例の向清 TSH 量は正常傾を示した。乙のう ち 1 例は 2 カ月にわたり間脳レ線照射（線量合計 2080 レンドン）を受け，若干血中 TSH 量の減少を来す と共に血清コレステロールはやや上昇し, PBI は少しく低下し, 眼球哭出度むやや減少在見た（図 1 及び図 $15 \mathrm{C})$.
Fig. 2

(A) Serum TSH levels in normal subjects $\mathrm{mJSu} / \mathrm{ml}$ $1.30 \leqq$ normal adults $\leqq 2.20$ a total of 41 cases, $\mathrm{P}=0.05$ normal adult males (above the 2 nd decade) $1.59 \pm 1.28$ (a total of 20 cases) $\left\{\begin{array}{l}1.82 \pm 1.38 \text { (15 cases, } 2 \text { nd } \sim 5 \text { th decades }) \\ 0.89 \pm 0.54 \text { ( } 5 \text { cases, above the } 5 \text { th decade })\end{array}\right.$ normal adult females (from the 2 nd the 3rd decades) $1.91 \pm 1.49$ (a total of 21 cases)

(B) A variation of the serum TSH level in season thick line: meanvalue of the 5 cases

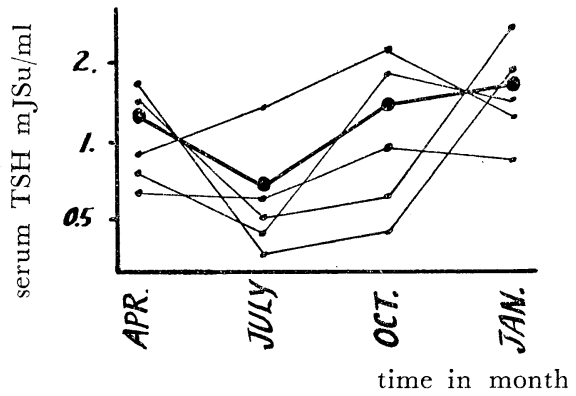

Fig. 3 Correlation between the serum TSH level $\&$ PBI value in a group of simple goiter

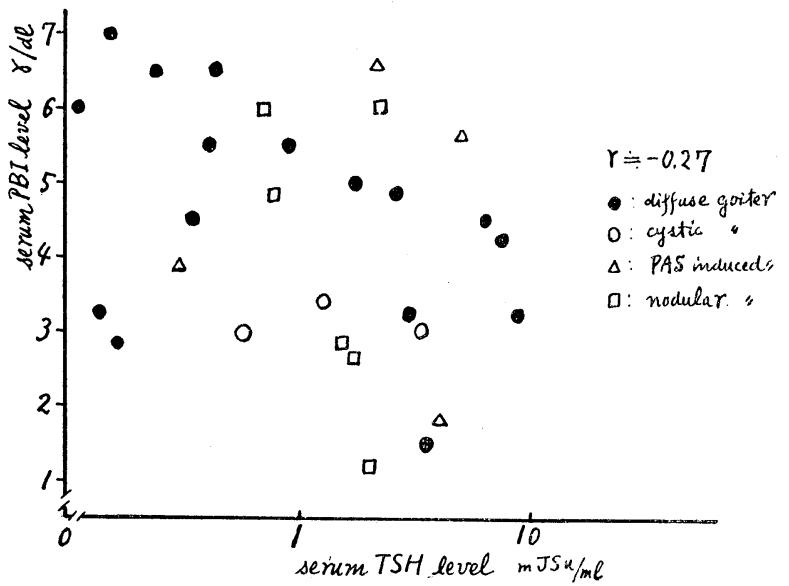


Fig. 4 Correlation between the serum TSH level \& PBI in the exophthalmic hyperthyroid group

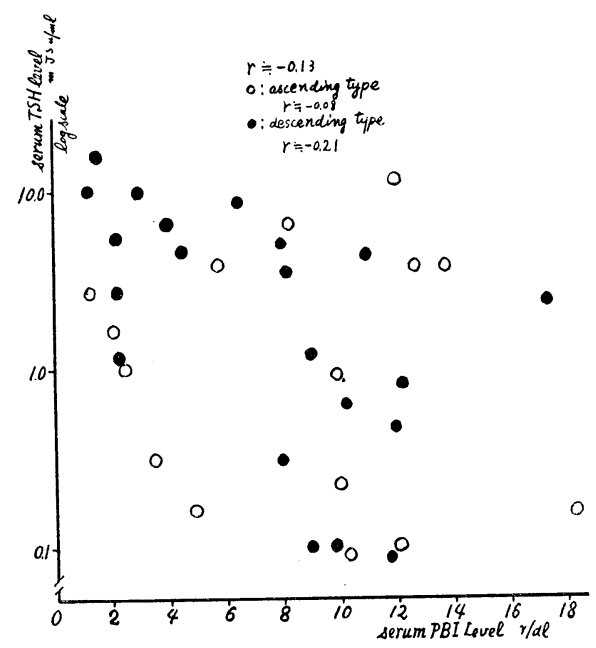

Fig. 5 Correlation between the serum TSH $\&$ PBI in the non-exophthalmic hyperthyroid group

$$
0 \text { : ascending type } \quad r=0.08
$$

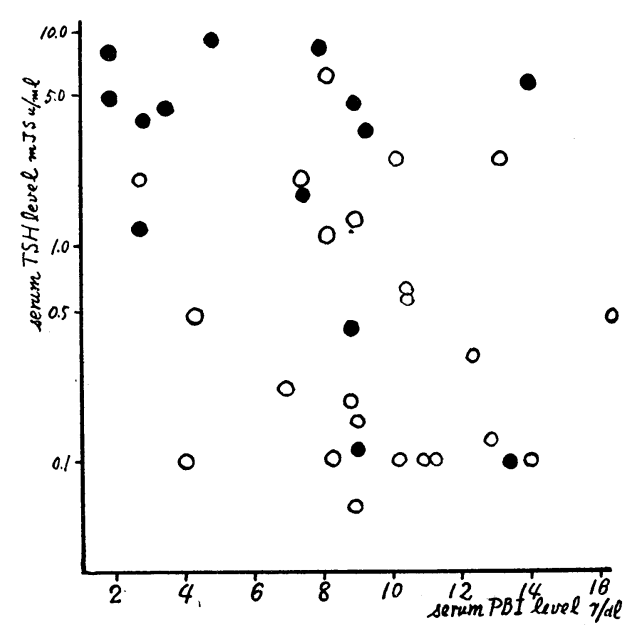

Table 5 Serum TSH levels of hyperthyroidisms

$$
\text { (a total of 73cases) } \mathrm{mJSu} / \mathrm{ml}
$$

Thyroidal $\mathrm{I}^{1.31}$ uptake $\left\{\begin{array}{l}\text { ascending type (37 cases) }: 2.04 \pm 1.61 \\ \text { descending type }(36 \text { cases }): 2.85 \pm 2.08\end{array}\right.$

$$
\begin{aligned}
& \text { with exophthalmos } 36 \text { cases } \\
& 2.73+2.26 \\
& \begin{array}{c}
\text { ascending type : } 13 \text { cases } \\
2.45 \pm 1.89 \\
\text { descending type : } 18 \text { cases } \\
3.04 \pm 2.81
\end{array} \\
& \text { with goiter } 33 \text { cascs } \\
& 2.24 \pm 1.79 \\
& \left\{\begin{array}{c}
\text { ascending type : } 20 \text { cases } \\
1.99 \pm 1.38 \\
\text { descending type : } 13 \text { cases } \\
2.68 \pm 2.03
\end{array}\right. \\
& \text { without goiter } 4 \text { cases } \\
& 2.12 \pm 1.63 \\
& \left\{\begin{array}{c}
\text { ascending type : } 2 \text { cases } \\
1.98 \pm 1.08 \\
\text { descending type }: 2 \text { cases } \\
2.27 \pm 1.60
\end{array}\right.
\end{aligned}
$$$$
\left\{\begin{array}{c}
\text { with goiter } 31 \text { cases } \\
2.87 \pm 2.29 \\
\\
\text { without goiter } 5 \text { cases } \\
2.46 \pm 1.89
\end{array}\right.
$$

\section{4) 甲状腺機能六進症に於ける血清 TSH 量と PBI}

甲状腺機能九倠症を眼突者伴う群と伴わざる群とに分類し，更に各々を甲状腺 $\mathrm{I}^{131}$ 掑取率曲線の上昇型 
を示す群と下降型を示す 群とに分けてその血清 $\mathrm{TSH}$ 量と PBI 值との 相関を検するに，何れも その相関係数は極めて低 值を示し, 眼突を伴う下 降型にやや有望なる值を 得たが，有意水準に達す るには低值に過ぎるよう であつた(図4及び5).

5）甲状腺機能六進症 に於ける血清 TSH 量と $1^{131}$ 撕取率

甲状腺 $\mathrm{I}^{191}$ 蛽取率 (24 時間値）と血清 $\mathrm{TSH}$ 量 との相関を PBI との場 合と同様に分類して検索 したがこの相関係数は何 れも殆ど 0 に近い傎であ つた. しかし $\mathrm{I}^{131}$ 摄取率 6 時間値を以つて検すれ ば，何れむ明らかに正の 相関を示し，有意性は認 められなかつたが，その 相関係数は PBI との夫 よりもむしろ幾分高値を 示した（図6，7）.

6) 各種抗甲状腺剂の 血清 TSH 量に及ぼす影響

これらの䑁用は何れむ 甲状腺機能充進症に対す る治療の目的で投与され たものであるが, methylthiouracil (MTU) 0.1 ～0.3gr./日 経口投与 3 週 後 4 例中 3 例に血清 $\mathrm{TSH}$ 量の有意の上昇を認めた (図 $8 \mathrm{C}$ ).

mercazole (1-methyl2-mercaptoimidazole)

15 40mg/日 3 週間経口 投与では 9 例中 3 例に有 意の増加を，3 例には増
Fig. 6 Correlation between the serum TSH level \& the thyroidal $\mathrm{I}^{131}$ uptake rate $(6 \mathrm{hrs})$ in the exophthalmic hyperthyroid group

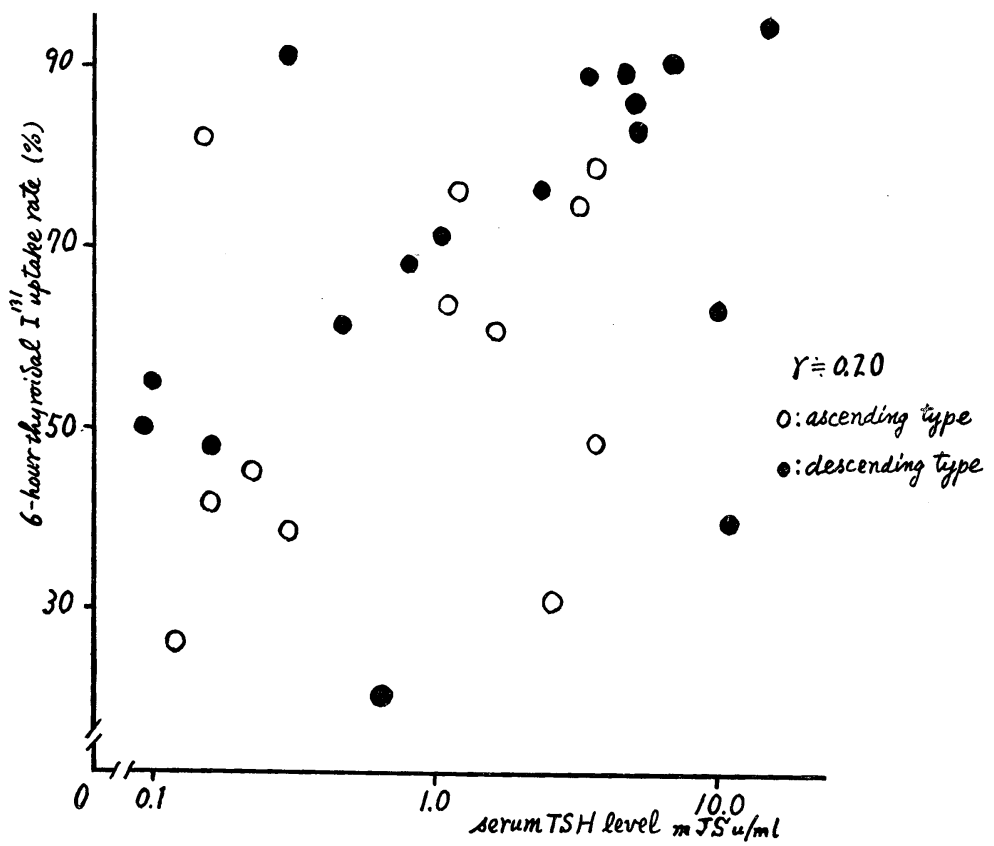

Fig. 7 Correlation between the serum TSH level \& the thyroidal $\mathrm{I}^{131}$ uptake rate (6hrs) in the non-exophthalmic hyperthyroid group

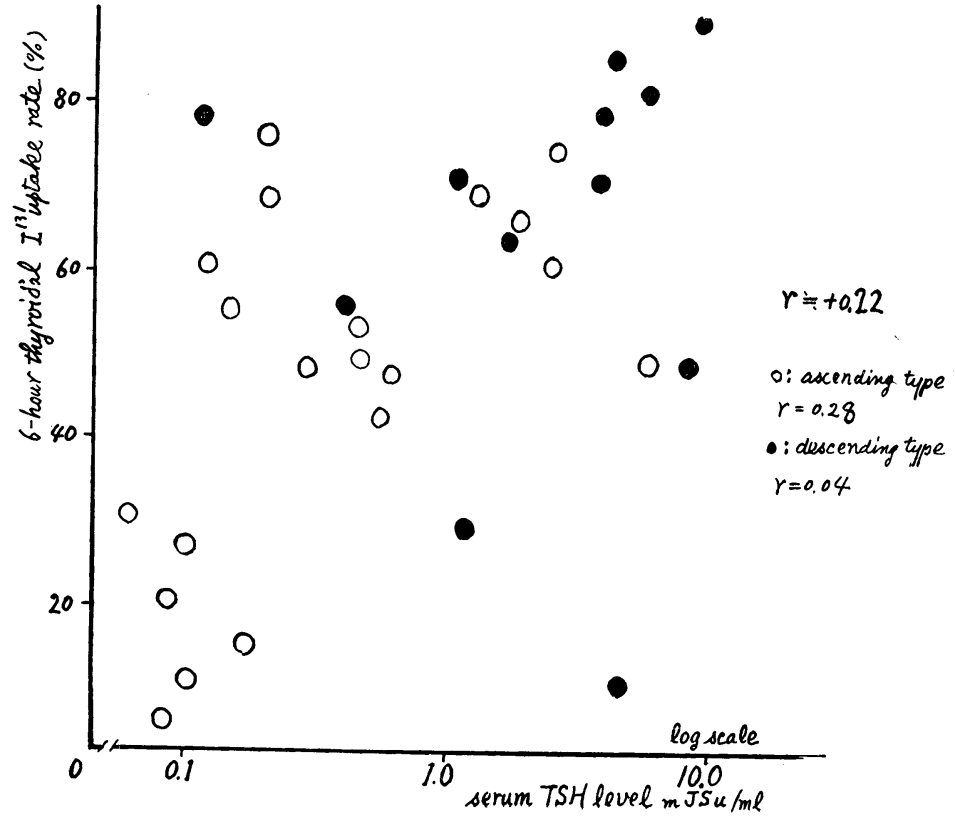

第35巻 第11号 
Fig. 8 Effects of some medications on the serum TSH level

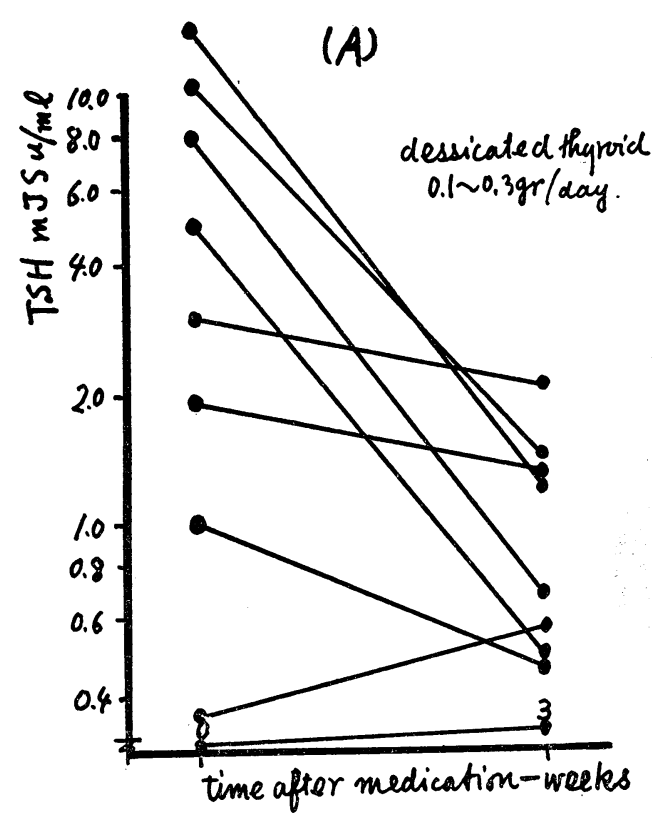

(B)
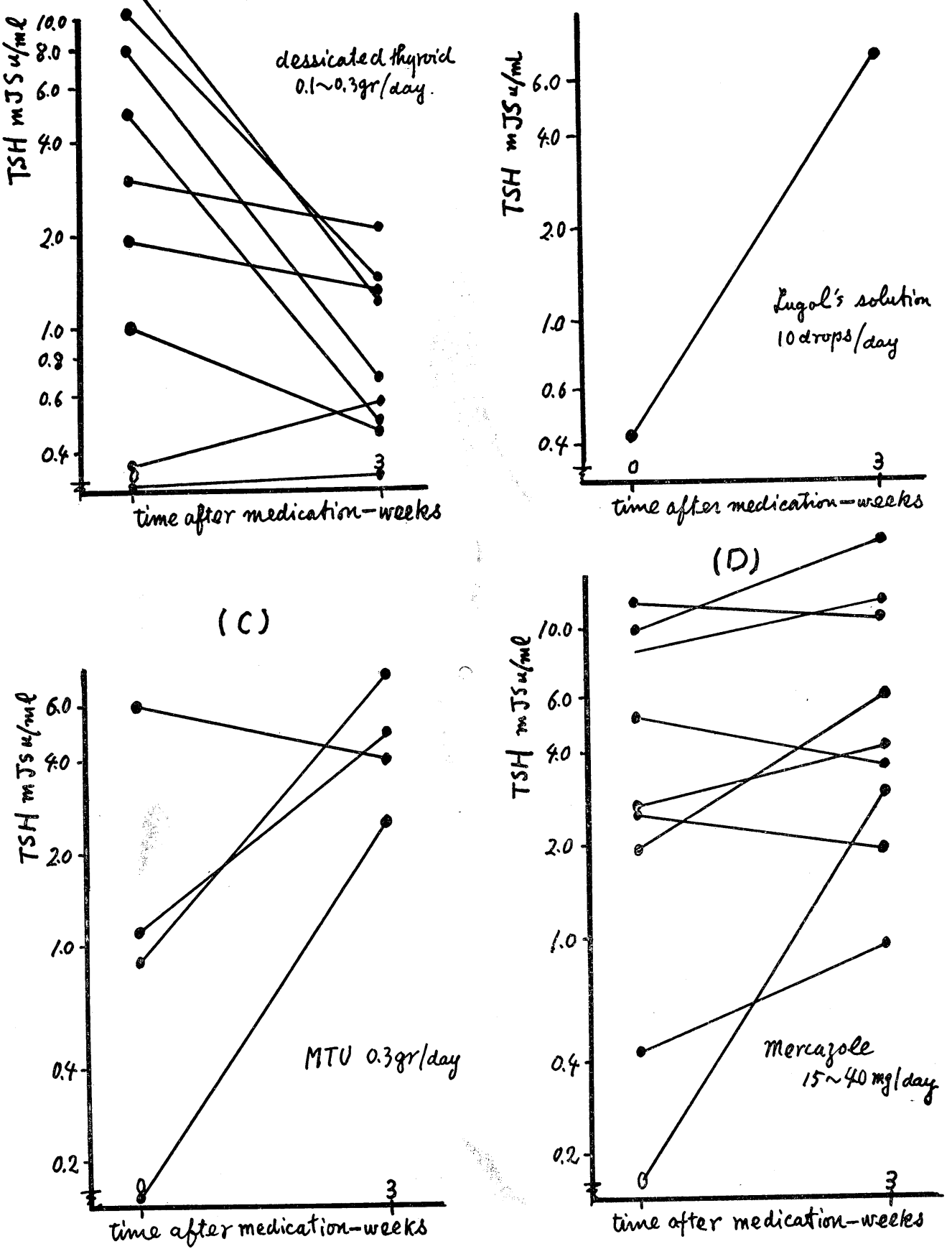
加の㖽向を，3例はやや下降の傾向を示した（図 8 D)．

Lugol 氏液投与例は, 半年前に $\mathrm{I}^{131} 3 \mathrm{mC}$ を内服したが再発の徵を示した Basedow 氏病で, Lugol 氏液 平均 1 日10滴 3 週間投与によつて BMR は明らか改善された 1 例であつて, その血液 TSH 量怙有意の 上昇を来している（図 $8 \mathrm{~B}$ )。

7） $\mathrm{I}^{131}$ 療法を受けた甲状腺機能亢進症に於ける血液 TSH 量の変動

$I^{131}$ 療法を受けた17例中11例は30才台の女子であり，びまん性甲状腺腫と眼突とを借えた Basedow 氏病 で, 投与 $\mathrm{I}^{131}$ 量は $2 \sim 8 \mathrm{mC}$ であつた。治療前の TSH の量は 3 例は正常䉤囲に，5例は明らかに異常高 值, 残り 8 例は正常以下であつた。. $\mathrm{I}^{131}$ 投与後 $1 \sim 3$ 力月で12例中 7 例は投与前值より高值を示し, 2 例は 却つて低值を示し，4 - 6 力月後で 7 例中 4 例は下降の傾向を示したが， 7 〜 カ月後では 5 例中 3 例がな 打有意の蒿值にあり，その中 2 例は更に上昇の傾向を示した（図 9 ). Basedow 氏病（33才男子例）に ${ }^{131}$

Fig. 9 Changes of serum TSH levels after administrations of $I^{131}$ for treatments

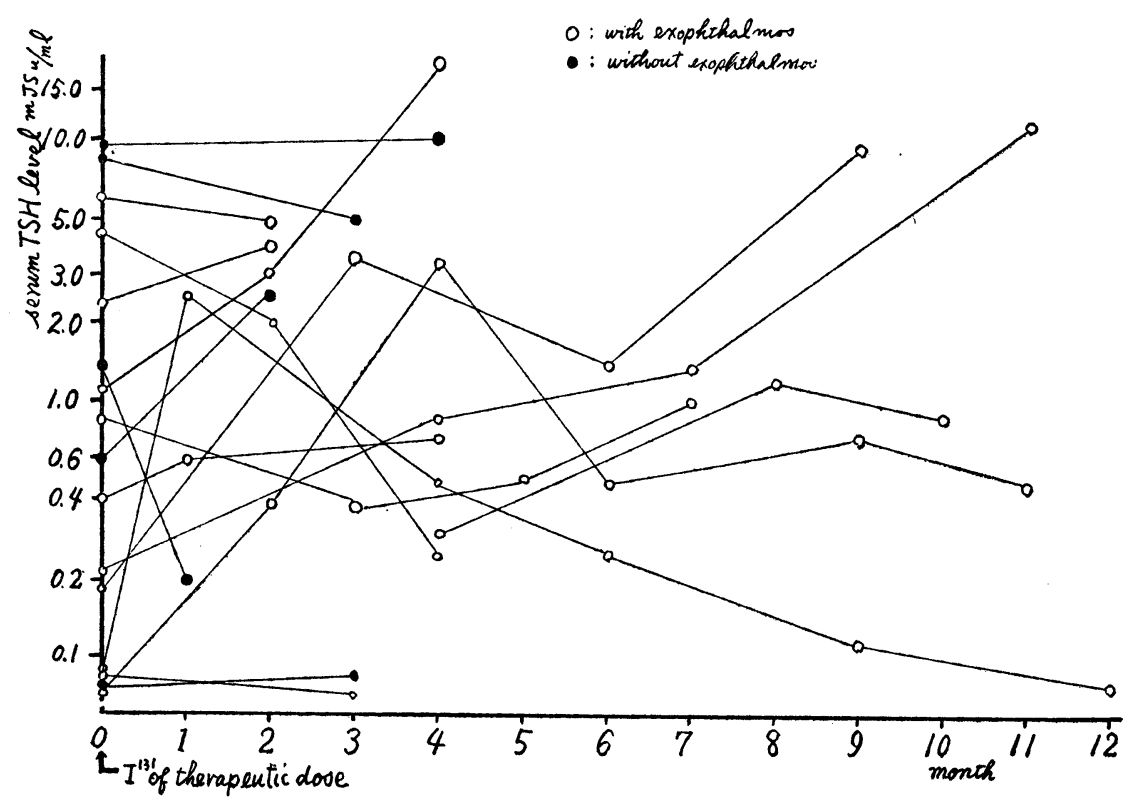

$3 \mathrm{mC}$ 投与した芬合血清 TSH 量の変動は他の諸検查成績の変化に幾分先駆するようであるが，ほぼ平行関 係にあるととが認められた（図10)

\section{8）甲状腺末の血清 TSH 量に及ぼす影響}

9 例の原発性甲状腺機能低下者に甲状腺末 $0.1 \sim 0.3 \mathrm{gr} /$ 日を 3 週間投与した場合， 5 例は明らかに血清 TSH 量の低下を来し， 2 例は低下の傾向，1 例は不変，1例は上昇の傾向を示した。 TSH 量不変或は上昇 を示した㭧者の甲状腺機能は他例に比䡥してとくに低下が著しいと言うこともなく, 又発病よりの経過期問 が長いというととも認められなかつた（図８Ａ）。

9）血清 TSH 量に及ぼす triidothyronine $\left(T_{3}\right)$ 並びに thyroxine $\left(T_{4}\right)$ の影響

㭴度のびまん性甲状腺腫を有する単純性甲状腚腫の 1 例 (19才女子) 亿 $\mathrm{T}_{3} 500 \mu \mathrm{g}$ を觔注し26時間後血清 TSH 量の有意の低下を認め，24時間後に於いても有意の低下が持続されることを観察した（図11，(A)). 之に反し Basedow 氏病の1 例（23才女子，血清 PBI 9.98\%/dl； $1^{131}$ 24時間掑取率 59\%_上昇型；BMR, + $31.6 \%$ ；）に同量 $\mathrm{T}_{3}$ を投与したが，血清 $\mathrm{TSH}$ 量は有意の変動を示さなかつた（図11(A)）。

健常者 2 例に $\mathrm{T}_{4} 800 \mu \mathrm{g}$ を経口投与して 3 時間後既に血清 $\mathrm{TSH}$ 量の下向を見，12時間後では有意の低下 
を垫めたが，しかし予想以上に $\mathrm{T}_{4}$ の作用即 ち血清 TSH の低下は軽度であり, その持続 時間む短かく24時間後むはや再び上昇の傾向 を示した (図11，(B)). 而して $\mathrm{T}_{4}$ 投与前血 清 TSH 量高值を示した症例に於いては $\mathrm{T}_{4}$ 投与によつて 24 時間後 $10 \%$ 以上の BMR 上 昇を見たが，他の症例では有意の変動なく， 又24時間甲状腺 $\mathrm{I}^{131}$ 摂取率䎲至つては 2 例共 僅か $2 \%$ 前後の低下を示したに止まつた。 な お尀状腺機能立進症の 1 例にも同様の処置を 行つたが血清 TSH 量, BMR 及び甲状腺 $\mathrm{I}^{131}$ 提取率は共に変動を示さなかつた（図11 (B)）。乙のほか Basedow 氏病の 2 例は前 值が夫々0.11及び $0.23 \mathrm{mJSu} / \mathrm{ml}$ であつて, $\mathrm{T}_{3}$ 投与によつて 本法の測定可能限界以下に 低下したため， $\mathrm{T}_{3}$ の血清 TSH 量に及ぼす
Fig. 11 (A) Effect of triiodothyronine on the serum TSH levels

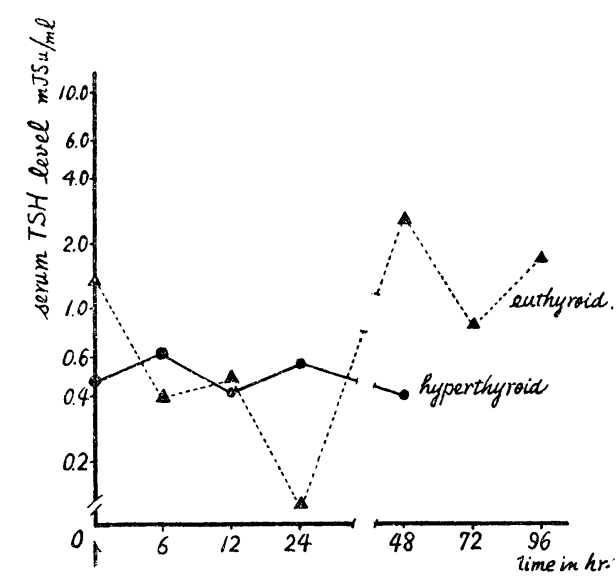

triidothyronine $500 \gamma$, intramuscular.

Fig. 11 (B) Effect of thyroxine on the serum TSH levels

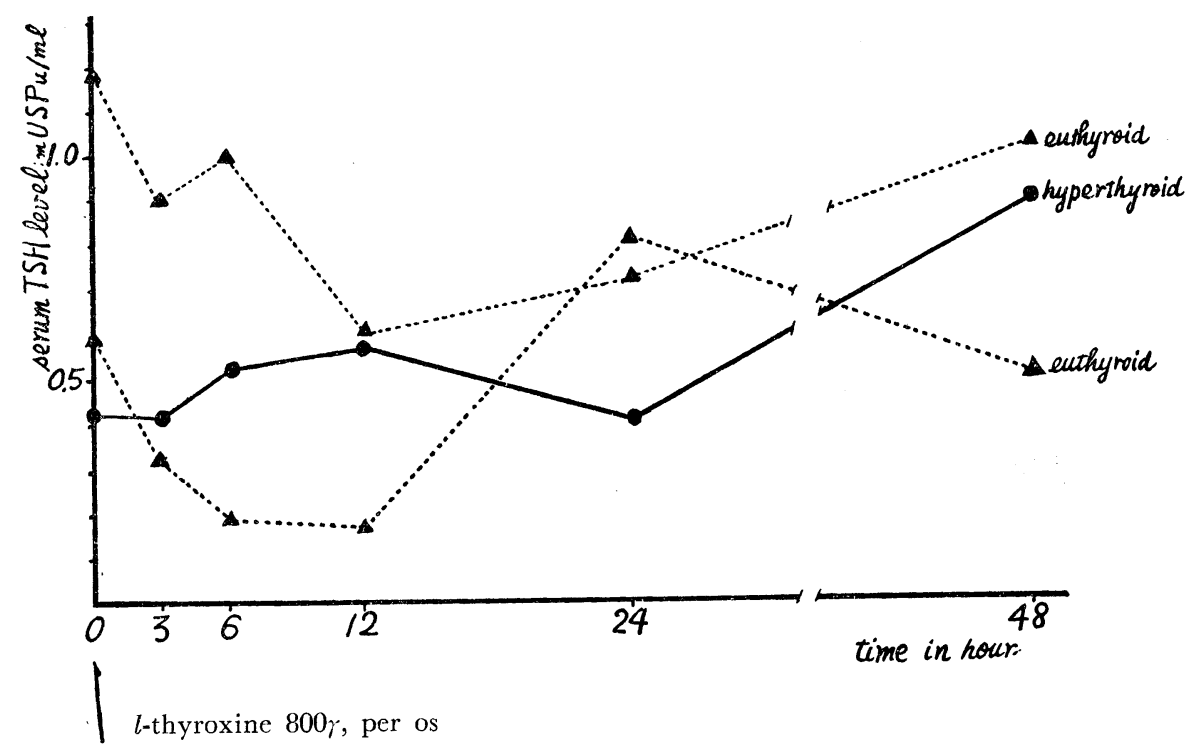

效果を判断することが出来なかつた。

10）甲状腺機能正常者及び異常者に於ける TSH 負荷後に於ける血清 TSH 量の变動（図12）。

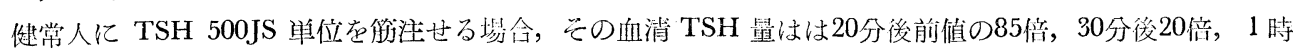

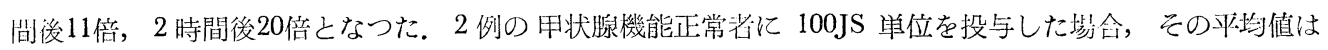
20 分後 4.6 倍, 30 分後1.6倍, 1 時間後 3.1 倍, 2 時間後 2.7 倍之なつた。

单純性甲状腺腄 1 例飞 500 单位在投与世万場命仗 30 分後 15 倍, 60 分後 1.5 倍, 2 時間後 1.8 倍となり, 原

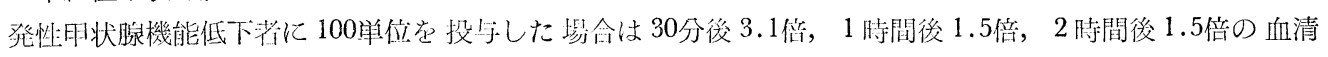
TSH 量を示した. 
Fig. 12 Changes of serum TSH levels after injection of TSH ("Pretiron" Schering)

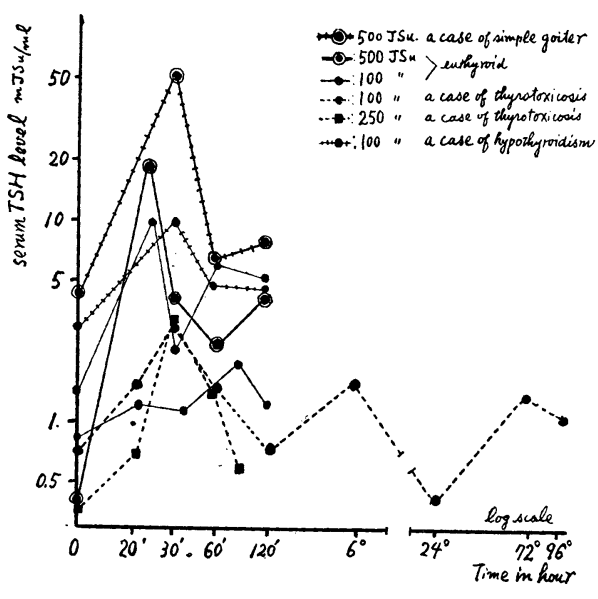

Basedow 氏病（32才男子， BMR $+40 \%$, PBI $13.1 \gamma / \mathrm{dl}, \mathrm{I}^{131}$ 摄取率 $80 \%$ ，1 日推定ホル モン産生量 $1176 \gamma$ r) そ250 単位を投与せる場 合，20分後2.3倍，30分後 9 倍，60分後 4 倍, 90 分後1.9倍となり，なお本例は $\mathrm{I}^{131}$ 摂取率 が100\%近くに迄上昇した。更に1例(52才男 子， $\mathrm{BMR}+37.9 \%, \mathrm{PBI} 4.8 \gamma / \mathrm{dl}, \mathrm{I}^{131}$ 摂取率 $39 \% ， 1$ 日推定示産生量 $640 \gamma$ ）に100単位を 負荷した場合 20 分後 3.6 倍，30分後 2 倍， 1 時間後1.4倍， 2 時間後1.3倍となつた. 本症 例は更に TSH 200 单位追加することにより PBI は $8.2 \gamma / \mathrm{dl} ， \mathrm{I}^{131}$ 摄取率は $82.3 \%$ 亿上昇 した. 負荷 TSH 量 100 単位の各症例に就い て比較すれば，負荷 TSH の血中より消失の 早いのは Basedow 氏病, 機能低下者, 正常 者の順となる。しかしこの様な比較方法には

Fig. 13 Serum TSH level in various diseases

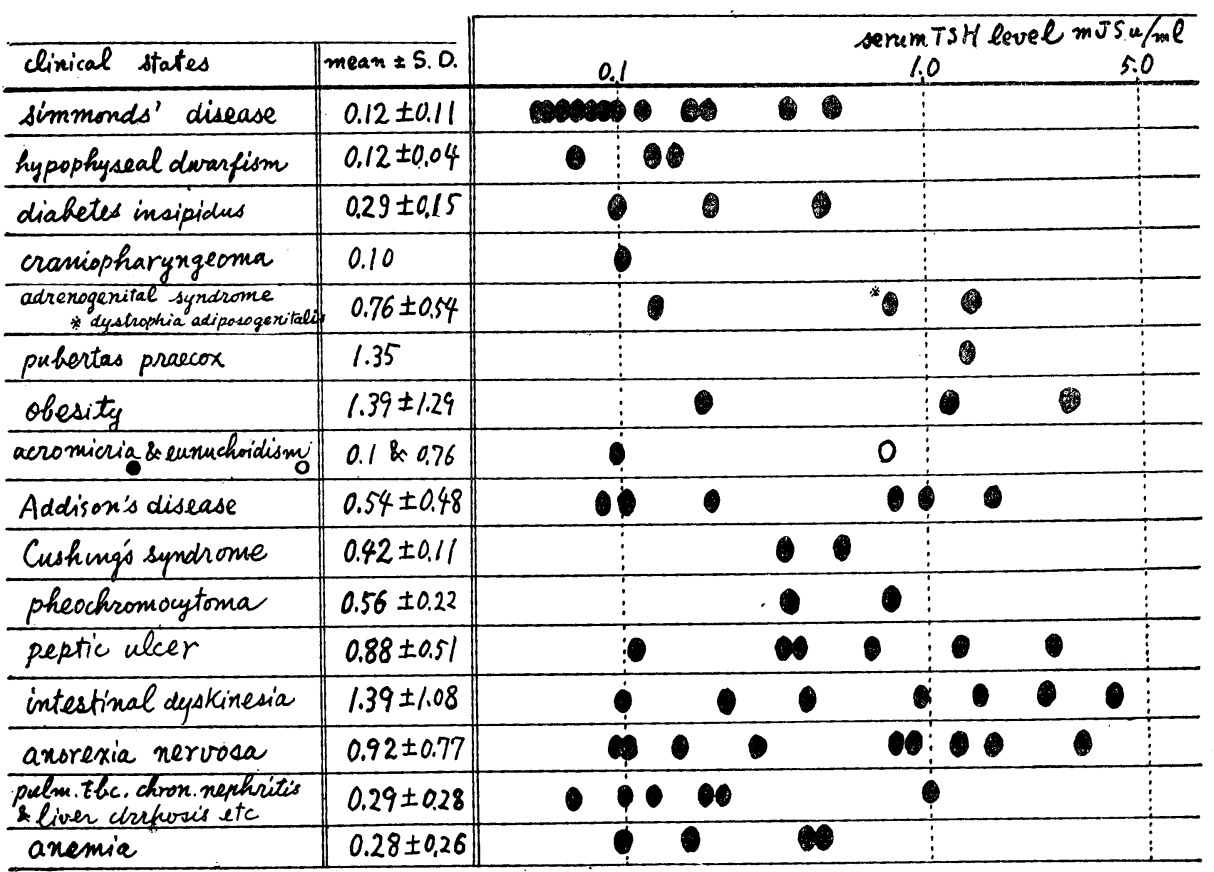

考慮の余地があることは云うまでもない.

11）甲状腺以外の各種内分泌疾患及びその他の疾患に於ける血清 TSH 量（図13）.

汎下垂体機能低下症に於いては，本法を以つて測定不能であつた 7 例を除いても，全般に低值が認められ た.

下垂体性侏儒症では 1 例測定不能, 他の 2 例は低傎を示した.

永崩症 3 例, 頭蓋咽頭腫 1 例も低值を示したが，乙れらの甲状腺機能に明らかな低下は認められなかつた。 
adrenogenital syndrome の1例はやや高值，1例はやや低值，dystrophia adiposogenitalis の 1 例はほぽ 正常值を示した. これらの甲状腺機能は何れも殆んど正常域にあつた.

pubertas praecox, pheochromocytoma 及び eunuchoidism の各症例は正常範囲, 単純性肥胖症 3 例では 高低半ばし, acromicria の 1 例は低值であつた. 甲状腺機能は何れも正常, 或は稍々低值を示した.

副腎機能低下症では 3 例が出常值， 3 例が異常低值であつた．その甲状腺機能はやや低下の状態にあつ た

Gushing 症候群の 2 例はやや低值にあつた. 甲状腺機能は何れあほぼ正常であつた.

甲状腺機能に特記すべき異常を認めなかつた 6 例の消化性潰瘍患者は正常人より幾分低值を示すすのが多 く, 神経性食思不振症の 9 例に於いてもその傾向があり, 腸運動機能失調症の 7 例は正常者と殆んど同じ血 清 TSH 量を示した.

重症肺結核 1 例, 肝硬変 (未期) 2 例, 胃癌 (未期) 2 例, 及び慢性腎炎 1 例の慢性消耗性疾患に於いて は何れあ低值であつた。

12）血清 TSH 量亡尿中排泄 17 OHCS との関係（図14）

消化性潰瘍，腸運動機能失調症，及び神経 性食思不振症の19例に就いて尿中排泄遊離

17-hydroxycorticosteroids (17-OHCS) と 血中 TSH 量之図14）の如く負の相関を示 したが，有意性は認められなかつた。

13）血清 TSH 量に及ぼす副腎皮質刺戟ホ ルモン及び副腎皮質ホルモンの影響

神経性食思不振症及び腸運動機能失調症の 症例に Prednisolone（塩野義製 Predonine） 5〜15mg/日経口投与を行い7日後に於いて 8 例中 4 例の血清 TSH 量有意の増加, 1 例 に減少の傾向を見た（図15，A）。他の8名 の同症例に ACTH-Z25 単位筋注後48時間で 8 例中 4 例に有意の増加を認めたが，2 例は 逆に有意の低下を示し，他の 2 例む低下の傾 向を示した（図15，B）。

14) Vasopressin の血清 TSH 量に及ぼす影響

尿崩症患者に Vasopression tannate 5 単位を皮注して血清 TSH 量の変動を見るに，図16）の如く明ら かな増加が認められた. Vasopressin 投与前後に於ける甲状腺機能は検査されていない.

考案

著者の TSH 測定法を臨床に応用して得た成績は以上の如くであり，全般に満足すべき結果とは必ずし あ云えないが，或る程度の知見を得るととが出来たと信ずる. 以下順を追つて考察を進める.

本法の特異性を検討した実験に於いて，著者は Schering 製 Anteron（血清性性腺刺㦸ホルモン）及び Primogonyl (䄉毛性性腺刺战ホルモン) に推計学上有意の TSH 活性を検出した. このととは Bakke et $\mathrm{al}^{36)}$. 及び Florsheim et $\mathrm{al}^{37)}$. 屯同様に認めており何れも contamination によるものとしている. Florsheim

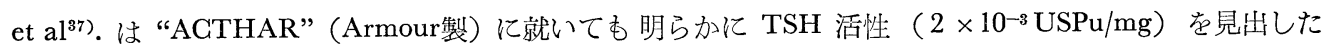
が，著者が ACTH “Schering” に認めた TSH 効果は推訃学上有意でなかつた．越智"39，ACTH が slice の $\mathrm{I}^{131}$ 摂取を抑制するととを認めているが，著者が $\mathrm{I}^{131}$ 放出法で検討した結果では少なくとも甲状腺機能 
Fig. 15 Effects of some treatments on the serum TSH-levels in various disorders
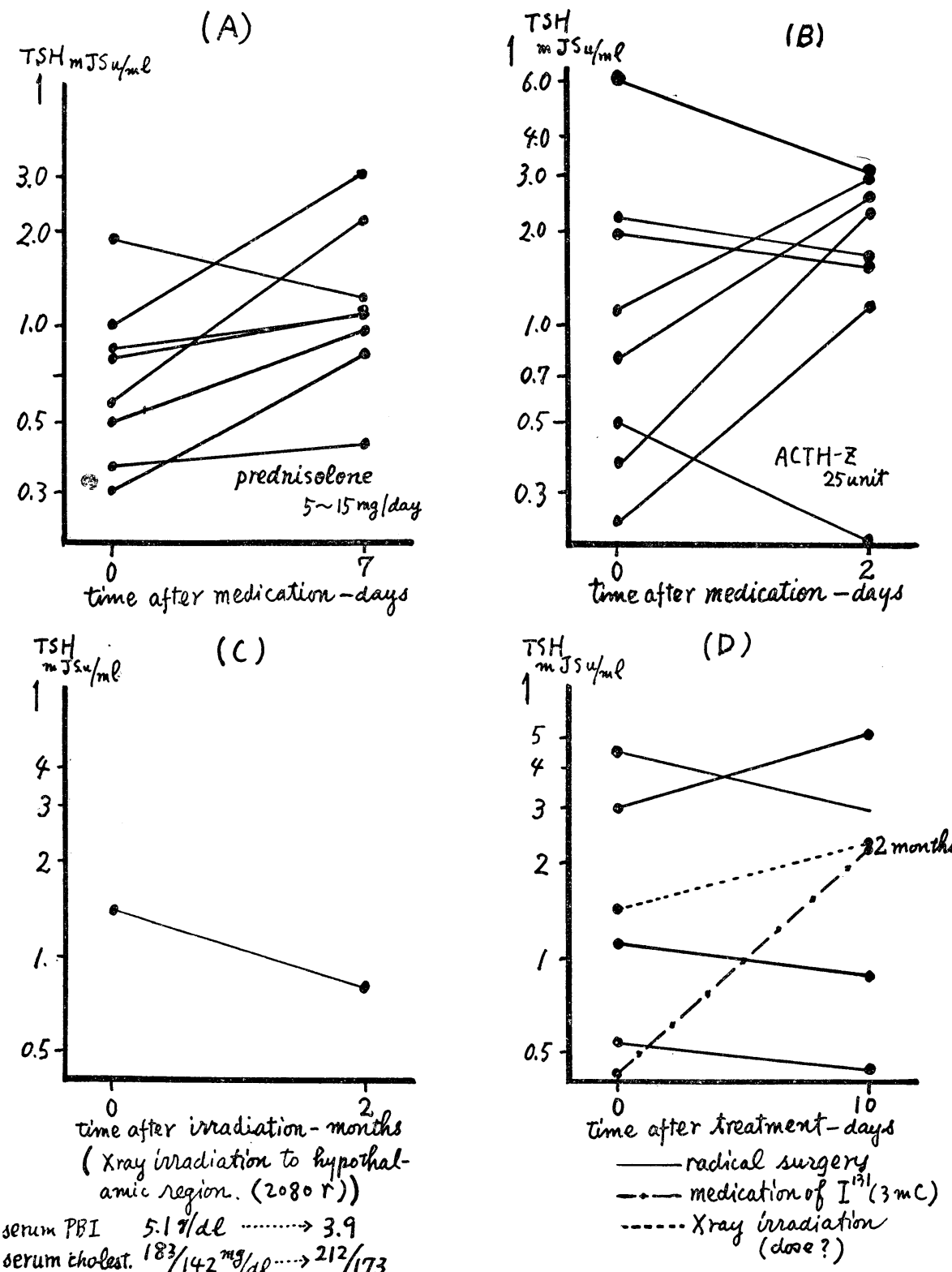

serum cholest. $183 / 142 \mathrm{mg} / \mathrm{al} \rightarrow \rightarrow 212 / 173$

exoph.grade $22.6 \mathrm{~mm} \rightarrow \cdots 19.9 \mathrm{~mm}$

\section{を抑制する傾向は認められなかつた。}

Chorionic gonadotrophin に TSH 活性が認められたが，妊婦に於いては下垂体よりむむしろ胎盤で産 生される TSH が主役を演ずるという見方が強い ${ }^{28}$ 現在にあつては奇異とするに当らない. Van Wagenen et $a .^{39}$ は妊婦尿中に於ける TSH 増量を, 島貫 ${ }^{28}$ は妊婦血中 TSH 量の上昇を認め, 著者も 1 例甲状腺中 毒症の弤婦 ( 3 力月) に血清 $\mathrm{TSH}$ 量 $10 \mathrm{mJSu} / \mathrm{ml}$ 以上を経験した. 又赤須等 ${ }^{40)}$ 及び島貫 ${ }^{28}$ は人胎盤より 
Fig. 16 Serum TSH level after injection of vasopressin

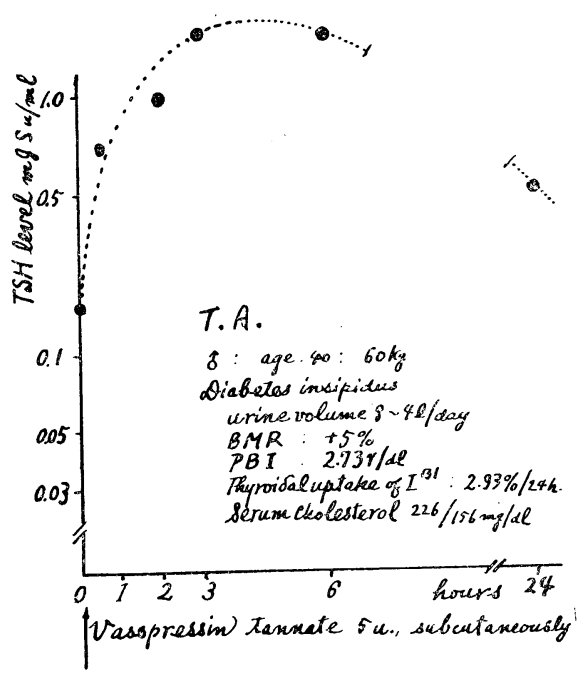

$\mathrm{TSH}$ 様物質を 抽出し島貫は $10 \mathrm{gr}$ の胎盤に 約 $13 \mathrm{mJS}$ 単位の TSH 活性を報告してい る. 一方, 東条, 矢野等 ${ }^{41)}$ は, Pretiron の gonadotrophin contamination に就いて報告 しているが，乙れ等は何れあ製造過程に於け る分離が困難なために混在を免汃れ得ない結 果によるものと解するのが妥当のようで, 事 実 Florsheim et $\mathrm{al}^{37}$ ) は gonadotrophin, $\mathrm{ACTH}$ に於いて, 純度の高い製剂程 TSH 活性が低いことを報告している。

人血清 $\gamma$-globulin の示す TSH 効果も TSH contamination によるものと解せられ る. 血清中の TSH は, Cohn $^{42)}$ によれば $\beta$ globulin に, Querido et $\mathrm{al}^{43)}$. によれば不定 であるが, Mc Kenzie ${ }^{21)}$ によれば，r-globulin fraction に認められ, 又 Postel ${ }^{44)}$ 亿よれば TSH を投与した場合む $r$-globulin と一しよ に泳動するという。

albumin の TSH 活性は著者同様 Bakke et $\mathrm{al}^{36)}$. 屯認めていない. 綜合アえノ酸製剤も著者の検討の結 果ではTSH 效果を示さなかつた。

Bottari $^{45)}$ は，馬血清添加により in vitro に於ける海埧甲状腺組織の $\mathrm{I}^{131}$ 摂取率が昂まるととを述べてお り，血清に含まれる TSH そのものの影響を除外しても, in vitro では添加血清が非特異的に incubation 全般に好影響を与えることは否定出来ない，故に著者は被験血清の稀釈倍率を常に一定にしているが，Sta－ ndard には血清成分を添加せず，又 TSH 負荷後採取した血清で TSH 量が高いと予想されるものは稀釈 倍率を大きくし，Simmends 氏病の如く TSH 量が低值と思われる場合は，その倍率をやや小さくしたと とを指摘しておく.

TSH 効果を抑制する物質の存在することは血嶈に就いて Postel ${ }^{44)}$, 脇坂等 ${ }^{23)}$, Heideman et $\mathrm{al}^{49)}$. が, 又尿に就いては, Starr et $\mathrm{al}^{51)}$., Greenspan et $\mathrm{al}^{132)}$ がその存在を認めている. Heideman et $\mathrm{al}^{49)}$. は牛甲状 脉 slice の重量増加率法 ${ }^{36)}$ を用いて血清 TSH 測定を行つたが不成功であつたので，その原因として血清中 に TSH 阻碍物質を想定してイオン交換樹脂による TSH 分離を試みているが，血清を添加した medium の滲透圧は变化する䇢であるから，むしろ甲状腺 slice 重量増加率法自体の欠陥と云うべきではなからうか。 小倉等 ${ }^{52}$ は血漿を10倍稀釈することによつて抑制作用を認めていないし, 著者もペパリン加血漿を資料とし た時 incubaticn 前後の slice の性状に外見上若干の差異を見るととが時としてあつたが，少なくとあ TSH 作用の抑制は認めなかつた。 TSH 抑制物質の性質，その由来に就いては不明であるが淐)，資料を抽出，濃 縮するか或は斯かる手技を経ずとも或る程度以上の濃度で用いることによつて非特異的, 非中毒的に作用す るのではないかと考えられる。

被験血清に TSH の既知量を添加して，その回収率を検し，著者は約74\%の回収率を得た。 小倉等 ${ }^{46)}$ は， 約 $80 \%$ の回収率を Bakke et $\mathrm{al}^{47}$. の原法で得たとし, Mc Kenzie ${ }^{21)}$ は Adams \& Purves ${ }^{48}$ の变法に於ける測 定誤差を約 $25 \%$ としてるが，乙の種の検定法として一応の限界を示すすのと云えよう.

正常人血中の TSH 量に就いては（表 1，2）に示される如く報告者によつて可成りの差異がある. そし て同一報告者でも発表の都度若干その数值を異にしている (D’Angelo et $\mathrm{al}^{15) \cdot 18)}$ ，小倉等 ${ }^{2452) 116)}$ ). Greer et $\mathrm{al}^{533}$. は甲状線機能正常者に於いては，1 日約 1 USP 単位の TSH が下垂体前葉より産出されると見做し， 人体内細胞外液量を約 $15 l$ と芫積つて, 血清 TSH 量は $0.06 \mathrm{milli} \mathrm{USPu} / \mathrm{ml}$ 前後であろうと推定してい 
る. Mc Kenzie ${ }^{21)}$ は正常人血漿の Cohn fraction II に $0.166 \mathrm{mUSPu} / \mathrm{ml}$ の TSH 活性を検出し, 正常人 血清 $1 \mathrm{ml}$ には約 $0.2 \mathrm{mUSPu} / \mathrm{ml}$ が含まれると想定した。著者が一年間を通し41例に就いて得た值は，約 $1.75 \mathrm{mJSu} / \mathrm{ml}$ (約 $0.175 \mathrm{mUSPu} / \mathrm{ml}$ であり，Mc Kenzie の推定 ${ }^{21)}$ にほぼ一致する．しかし著者が，先ず 6 月より 9 月の間に 12 例に就いて得た值は $0.67 \pm 0.48 \mathrm{~m} \mathrm{JSu} / \mathrm{ml}$ ， その後12月迄に測定した 18例を加算し たものでは男子14例につき $0.51 \pm 1.38 \mathrm{~m} \mathrm{JSu} / \mathrm{ml}$, 女子16例につき $0.87 \pm 0.64 \mathrm{~m} \mathrm{JSu} / \mathrm{ml}$, その後更に 5 月 迄に測定した結果を加算して男子 20 例が $1.59 \pm 1.38 \mathrm{~m} \mathrm{JSu} / \mathrm{ml}$ ，女子 21 例が $1.9 \pm 1.49 \mathrm{mJSu} / \mathrm{ml}$ であつ て, 平均 $1.75 \mathrm{~m} \mathrm{JSu} / \mathrm{ml}$ 前後となる. 茲に季節的影響による血中 $\mathrm{TSH}$ 值の変動が予想されるが，著者が 5 例について得た成績は之を裏付けるあのである. 著者 ${ }^{33}$ は牛甲状腺 slice の反応性が夏期に低下するてと を指摘すると共に，2，3 の文献を引用して考察を進めたが，吉川 ${ }^{54)}$ 及び渡辺等 ${ }^{55}$ は人血清 PBI 值について， 又渡辺等 ${ }^{56}$ は豚甲状腺組織の酸素消費量について季節的変動を認め, 若干の文献的考察を行つている.甲状 腺機能を調節する TSH の血中量がその需要の低下する夏期に低值を示すととはけだし当然である.

性別による血中 TSH 量の差異に就いて，島貫 ${ }^{28)}$ は女子側に男子側よりも明らかに高值を認め，Bottari ${ }^{22)}$ は差異を認めなかつた，著者の例では幾分女子側に高值を認めたが，有意の差とは云えなかつた。

年令差については，島貫 ${ }^{28)}$ は弱年女子に相当の高值を, Bottari ${ }^{22)}$ は高年者に低值を認めている。閉経前婦 人が一般に TSH 高值を示すととは, 両人とも認めている. 又 Adams ${ }^{57}$ は家鬼, 廿日鼠, 白鼠について, Armstrong et $\mathrm{al}^{58}$. は豚について, 夫々人同様の年令的差異を述へ， Bakke et a ${ }^{599}$. は下垂体 TSH 含有量も 50才以上では低值であると報告している。著者の成績に於いても同様に50才以上の男子では幾分低值を認め た.

各種甲状腺疾患に於ける血清 TSH 量に就いて，先ず単純性甲状腺腫に就いては，小倉等 ${ }^{24)}$ にると平 均 $6.30 \mathrm{mJSu} / \mathrm{ml}$ で正常人 (平均 $0.65 \mathrm{mJSu} / \mathrm{ml}$ ) の約 10 倍であり, 河野等 ${ }^{25}$ 亿よれば 5 例に常き平均 $0.77 \mathrm{mJSu} / \mathrm{ml}$ であつて, 正常者 3 例（平均 $0.54 \mathrm{~m} \mathrm{JSu} / \mathrm{ml}$ ) より若干高值である. 又小倉等 ${ }^{24}$ によれば 甲状腺末の無効な結節性及び厒性甲状腺腫は正常以下の低值を示したと云う. Bakke et al ${ }^{59}$. は非中毒性結 節性甲状腺腫の 1 例に下垂体 TSH 含有量の低值を報告している，著者の成績ではびまん性甲状腺腫群が正 常者の約 1.3 倍であり, 囊腫性ではほぼ正常, 結節性ではやや低值, 最高平均值を示す PAS 甲状腺腫で2. 2 倍の高值を認めた。 PAS の長期投与で甲状腺の肥大增殖及び $\mathrm{I}^{131}$ 摂取率の低下を来すととは ${ }^{60)}$ ，本邦に 於いても阿部等 ${ }^{61)}$ が報告しており, 血中 TSH 量が上昇していることは想像に難くない, しかし Austin et $\mathrm{al}^{133)}$ ・は，サルチル酸剂は下垂体又はより高位中枢を介して甲状腺機能を抑えるという。

Greer ${ }^{62)}$ そよれば，非中毒性甲状腺腫の 発生はその原因の如何を問わず甲状腺ホルモン分泌不足に基ず く TSH 過剩分泌の結果招来される甲状腺実質の代償的肥大増殖によるとされる．尤すすべての甲状腺腪発 生について適用されるものでなく，又その TSH 分泌に過剩時期や分泌正常時期があることも推測されてい る. 著者の経験では一般に青年女子の単純性甲状腺腫例に TSH 高值が多く見受けられたが，甲状腺腫発現 時期に就いては曖昧で画然と時期的区分を行うことは出来ず，甲状腺機能に就いても全般にやや正常の低目 にあることに気付いたのみであつたが，乙れ等の患者に於ける血清 PBI 值と，TSH 量に逆相関が可成り の程度に認められたととは，甲状腺ホルモンの分泌不足が本疾患の発生に重大役割を演ずるとの從来の説を 或る程度裏付けるものと云えよう。 Greer ${ }^{63)}$ は TSH に，視床下部の支配を受ける growth factor と，そ の支配を受けない metabolic factor との 2 つがあるとし, 最近ての自説を確認しているが ${ }^{64)}$, Florsheim ${ }^{65}$ は白鼠を用いた契験でてれを否定する報告を行つており，問題の解決は未だ今後に期待されるところが多 い.

原発性及び下垂体性腺甲状機能低下症に於ける血中 TSH 量に関する諸家の報告は（表 2 ）に明らかなよ うに前者に於いて高く，後者に於いて低いが，著者の成績も之等に一致している。血中 TSH 值の測定は TSH 試験と共に甲状腺機能低下症の鑑別に役立つととは明らかである。しかし著者の経験では原発性に於 いて 3 例が正常或は正常以下の低值を, 下垂体性に於いて 2 例が正常值を示し, 前者のうち 2 例は甲状腺末 投与で血中 TSH 量の下降を来さなかつた。 
この様な異常は De Robertis ${ }^{12)}$ が 2 例について, D’Angelo et $\mathrm{al}^{15)}$. が 7 例について Gilliland et al ${ }^{19)}$. が 2 例について報告し, 粘液水腫状態の長期持続の結果下垂体自体の代謝が低下して TSH 産生分泌が減退す るために血中 TSH 量は低下し，甲状腺ホルモンを与えると下垂体の代謝活性が昂まり血中甲状腺ホルモン 量が抑制効果を発揮するまで TSH 産生分泌が増加を続けるため血中 TSH 量は上昇すると推定しており， DiGeorge et $\mathrm{al}^{17}{ }^{18)}$. 屯亦かかる二次的な間脳・下垂体の機能低下が起ら 以以前の時期には血中 TSH の增量 があつたあのと考えている。但し, 著者の前述の 2 例にこの説明が適用出来るか否かは疑間である.

甲状腺癌について，小倉等 ${ }^{24)}$ は低值を，河野等 ${ }^{25}$ は 1 例高值を報告し，著者の成績でむ高低半ばしており 甲状腺癌に特有な血清 TSH 量の傾向は認められなかつた. 23 女子の 1 例では $0.42 〜 2.38 \mathrm{~m} \mathrm{JSu} / \mathrm{ml}$ と 大幅の変動がありながら，その甲状腺機能成績と一定の関係を示さなかつた.

甲状腺機能九進症に於ける血中 TSH 量に就いての記載を通覧すると，正常以下或は測定不能とする報告 と, 異常高值を示す一群及び異常低值を示す一群に分けられると云う報告とに大体 2 分出来る(表 2 ). 既に 述べた如く，血中 TSH 抑制物質の問題があるが，之は本症に限られた問題ではない．本症には TSH 異常 高值を認めないと主張する諸家の測定法では，その被験血液に含まれている多量の甲状腺ホルモンにより検 定動物自身の endogenous TSH 分泌が抑制されるという久陷のあり得るととは, Gilliland et al ${ }^{19)}$. が既に 指摘している通りである。しかし，ての様な甲状腺ホルモンの干捗があり得ない Bottari et al ${ }^{66}$. の in vitro に於ける有機 $\mathrm{I}^{131}$ 放出率測定法によつて得た成績でも，血清 TSH 異常高值を示す甲状腺機能穴進例は報 告22)されていない.

てれら諸家の夫々異つた成績を統一的に解釈することは，甲状腺機能立進症の成因を解明する手段に通ず るあのであつて甚だ困難であるが，De Robertis ${ }^{12)}$ それば甲状腺中毒症は血中 TSH 量低值を示す，即ち 下垂体系之直接関係しない型と，上位中枢である下垂体系の機能異常元進によると考えられる血中 TSH 高值の型とに分けられる. Gilliland et $\mathrm{al}^{19}$. は TSH 低值の群には眼球突出はあつても軽度で，血中 TSH 高值の群には眼突の著明な甲状腺中毒症が多いことを見出し，而して，甲状腺機能九進 即ち下垂体機能 の異常え進とし，眼症状の著明でない例では下垂機能立進が持続的でなく発作的に起り，そのために血 中 TSH 值は常には明らかな上昇を呈しないが，之に反して眼症状高度の例では，より継続的に下垂体の活

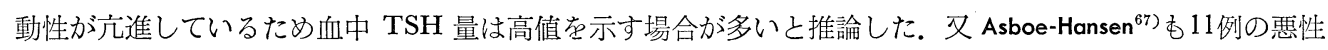
眼症状を呈する㭧者の裡10例に血中 TSH 值の上昇を認めている。しかし原発性甲状腺機能低下者では TSH 高值を示す例が多いに拘わらず眼症状は伴わないのを通常とする，故に眼症状を惹起するものは，乙 の様な TSH でなくて他に存在するであろうことは容易に想像出来る. Gilliland et al ${ }^{19}$ は重篤は眼症状 を呈ししか屯甲状腺機能正常である 3 例に TSH 高值を認めず，著者も同様な 2 例を経験している。乙の様 な観点に立脚して, 純粋な TSH 製剤とは催眼突作用の少ないてとから下垂体前葉より TSH とは別に所謂 Exophthalmos Producing Substance (EPS) を抽出分離したのは Dobyns et al ${ }^{68}$. であり，Jefferies ${ }^{69}$ も実 験的検討より同様の見解を，又 Lamberg ${ }^{70 \sim 72}$ は眼症状を主徴候とする所謂 thyrohypophysial syndome に 対する間脳下垂体レントゲン照射という治療面から以上の説を支持しているようである. Silverstini et $\mathrm{al}^{73}$. も $\mathrm{EPS}$ と TSH との差異に就いて述べ，血中に於いて TSH と EPS とは必ずしあ平行せず解離のあるこ とを見出している。 又 Friis et al. ${ }^{74)}$ exophthalmic euthyroid では $\mathrm{I}^{131}$ の転換率が旮進し， triiodothyronine の血中出現が少なく thyroxine より遅れることを見出している.

Adams et $\mathrm{al}^{8)^{9) 20}}$., McKenzie ${ }^{75)}$ は，甲状腺機能亢進症を来すむのとして下垂体の異常から産生分泌される “abnormal TSH, を考えている. “黑常 TSH” は甲状腺組織及びその機能に対しては従来の TSH と同様 に作用するが，作用発揮が遅く，血中停滞時間が長く，大量の甲状腺ホルモンよりその分泌法抑制されない， そして甲状腺組織に於ける蛋白分解促進作用が強力であろうとし，正常の TSH に他の物質が結合した形の あのであつて，恐らく Dobyns et $\mathrm{al}^{68}$. の云う EPS も “異常 $\mathrm{TSH}$ だろうと推論し，彼等自身甲状腺中 毒症の全例にこの異常を認めることは出来なかつたが，早晚証明される可能性のあることを指摘している.

Dobyns の EPS まで含めるのは聊か飛躍の感がないではないが，以上のほかに甲状腺機能進症に血清 
TSH 量の上昇が認められないととに対する 説明として，Rawson ${ }^{76)}$ は甲状腺機能儿進症では活性の高まつ た甲状腺や，その際黗々肥大を伴う胸腺，リンパ腺によつて TSH がより急速（正常者の 2 倍の速度とされ る）に不活性化されるため血中 TSH の上昇が見られないのであろうとした。

又 Bakke et $\mathrm{al}^{599}$. は最近甲状腺中毒症の 1 患者の下垂体に大量の TSH を見出し，乙れは分泌抑制によ る貯溜の結果でないとしている。

以上の下垂体性 TSH 説に対し，甲状腺機能充進症には必ずしも下垂体の異常を必要としないとする説翟 "8)す多くの根起を有する。即ち i）血中 TSH 量の上昇の認められない報告が多い. ii) その下垂体に多く は TSH 過剩分泌像が認められない年， iii）明らかな下垂体機能低下にも拘わらず甲状腺腫或は甲状腺中毒 症を来した症例が相継いで報告 ${ }^{80} 855$ されている等の事実である. Werner ${ }^{77)}$ あ TSH 過剩分泌説に全面的に は賛意を表しない一人であるが，彼によると，甲状腺機能立進症では TSH を投与しても $\mathrm{I}^{131}$ 摂取率及び BMR の上昇は僅少であり，又甲状腺ホルモンを投与してす正常人之は異なり $\mathrm{I}^{131}$ 掑取率は抑制さなず， この現象は同症の治瘾後も可成りの期間認められ，又眼突を有する甲状腺機能正常者にも認められるという。 Johnson, Greer et $\mathrm{al}^{78)}$. は闸状腺ホルモン分泌の面に於いても同様の現象を認め, 乙の本質的な異常之矛盾 しない考え方で本症の成因を論じなければならないとして実験的考察を進めたが，本症は甲状腺か或は視床 下部下垂体系か何れかの自律性機能亢進 (autonomous hyperfunction) に基ずくものであつて，甲状腺木 ルモンの抑制作用に対する視床下部下垂体系の感度が単に低下したためでないと結び, 満足すべき結論を得 ていない，しかし，有田 ${ }^{86}$ そよれば，甲状腺機能充進症では低下していると云われる TSH 感性す様々であ り, Johnson et $\mathrm{al}^{78}$. 鎮目 ${ }^{87}$ 亿よれば triiodothyronine 試験で上述の異常を示さぬ例外的な機能九進症が認 められている。

著者が対象とした甲状腺機能六進症73例の血清 TSH 值は $0.1 \mathrm{mJSu} / \mathrm{ml}$ より $10 \mathrm{mJSu} / \mathrm{ml}$ 以上にわたる 広範囲に分散し, 之等を $\mathrm{I}^{131}$ 摂取率曲線の型に分けると, 眼突群には下降型が多くこれ等の血清 TSH 做は 平均高值を示した。しかし有意の差は認められなかつた。

脇坂 ${ }^{35)}$ は，ささに放射性アイソトープによる検査を中心に甲状腺の病態生理を詳細に検討した結果，甲状 腺機能え進症には $\mathrm{I}^{131}$ 摂取率曲線が速やかに上昇して 比較的速やかに下る型（著者の下降型）と，上昇が 緩慢で且つ下降む極めてゆるやかである型（著者の上昇型）に分類出来るとし，前者はTSH の関与が比較

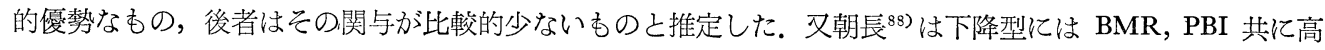
值を示するのが多く, 上昇型には BMR, PBI 共に低值を示すすのが多いとし, 両群に於ける甲状線組織像 の特徴を述へているが，著者の成績と共に，脇坂 ${ }^{35)}$ の指摘する如く甲状腺機能充進症に 2 型があり得るとと を示陖するものと云える。

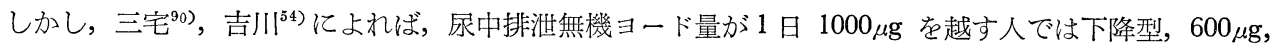
以下では上昇型を示すととが多いという。しからば，著者がTSH 高値を認めた下降型群にも摄取無機ヨ 一ドの影響があることは否定出来ない。しかし，ての程度の無機ヨードで下垂体の TSH 分泌が抑制される か否かについて定説はないが，恐らくあり得まい，そしてヌての程度のヨードがTSH を直接中和ないし不 活性化するととも著者の検討では明らかに否定的である。つまるとてろ無機ヨードが TSH の甲状腺細胞に 対する作用を直接抑制するとしてあ，而してての説が最も有力なようであるが，二次的に TSH の分泌が昂 進することが考えられるから，下降型が TSH の関与よりあむしろ無機ヨード摄取が多いために下降型を示 すに至つたすのと仮定しても, 乙れ等の群に血清 TSH 量高值が認められたとして矛盾はない. 又著者は甲 状腺機能え進症に於いて血清 TSH 量と PBI との間に相関を見出すととが出来なかつたが，乙れも本症で は甲状腺ホルモンによつて I ${ }^{131}$ 摂取及び放出が㳩制されないという Werner ${ }^{77)}$ Greer ${ }^{78}$ 等の主張と矛盾しな い.

著者は，血清 TSH 量と PBI 或は $\mathrm{I}^{131}$ 掑取率との相関関係を検するに際し，眼突の有無及び $\mathrm{I}^{131}$ 摄取 率曲線の型に分けて考察を加えたが，血清 TSH 量は血清 PBI 值よりも $\mathrm{I}^{131}$ 摂取率 (6 時間値) と稍々関

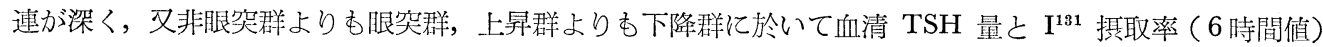


又は血清 PBI との関連がやや深いようであつた。 而して眼突群で下降型を示すすのが TSH 亿関聯深く, 事実それ等に於ける血清 TSH 量む平均最高を示したが，以上何れも推計学上有意性を欠き，てれを以つて 直ちにその一群を TSH，ひいては下垂体に結びつけるととは出来なかつた。

甲状腺機能六進症に MTU を投与した場合血清 TSH 量の上昇が認められたが，てれは MTU の甲状 腺機能抑制の結果招来されたものと考えられ, 表 2 ) に挙げた諸家の成績とも一致しており異論はない. し かし mercazole の影響に就いては，甲状腺に対し直接作用すると云うのが定説と思われるが，飯田等 ${ }^{911}$ は 組織学的検索より, 前沢 ${ }^{92}$ は甲状腺組織呼吸の面から, MTU とは態度を異にして mercazole が下垂体の

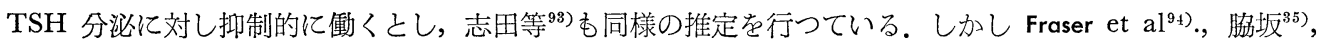
及び佐野等 $\left.{ }^{95}\right)$ はヨード代謝の面から直接甲状腺機能抑制作用を認めており, 又阿部 ${ }^{61}$ 等及び島 ${ }^{96}$ 等は組織学 的に検討した結果 mercazole は MTU と同様に作用すると述べ，Johnson，Greer et al ${ }^{788}$.の最近に於ける 研究も直接下垂体に Mercazole が作用しないという前提のもとに行われたものと考元られ，又実際に支障 を来していない，而して小倉等 ${ }^{24)}$ は甲状腺機能元進症及び正常犬に mercazole を投与して血漿 TSH 量の 上昇を認めている，著者の成績では, mercazole は MTU 程明らかではなかつたが, 同様に血清 TSH 量 の上昇を来すすのと考えられる。

著者は Lugol 氏液を投与した Basedow 氏病の1 例に血清 TSH 量の上昇を認めた。 無機ヨードが下垂 体に及ぼす影響に就いてもなお不明の点が多い，即ち，i）下垂体の TSH 分泌を直接抑制することむ考元

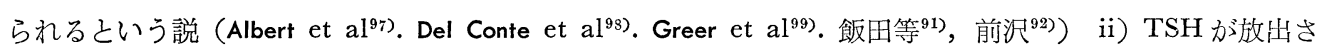
れて後或る点でてれを直接中和ないし不活性化するとする説 (Goldsmith et al ${ }^{100)}$.) 及び iii) 甲状腺細胞に 対するTSH の作用を抑制するという説（Werner ${ }^{77)}$, Benua et $\mathrm{al}^{1011}$.) 等がある. 而して iii) の説が最す 有力であり，臨床上見られると云う “iodogenic Graves' disease”, 或は Plummer type の症例にヨード療 法の効果が弱いとと, 又 triiodothyronine test の意義等より類推してあ iii) 説に妥当性があるが, 更に検 討を重ねてから結論づけねばならない， I ${ }^{131}$ 療法によつて血中 TSH 量が上昇するととは十分予想され，河 野等 ${ }^{25)}$ あ $\mathrm{I}^{131}$ 投与後 1 カ月以内に TSH 量上昇を認めている。著者の症例は一般に若年者であつたため投 与 $\mathrm{I}^{131}$ 量は計算上必要とされる量の半量以下であつたが，9 カ月以上を経た 4 例中 3 例になお有意の TSH 量の増加を認めたことは， $\mathrm{I}^{131}$ 治療効果の長期持続を物語るものとも云える.

甲状腺切除術又はレ線照射を受けた悪性甲状腺腫には血清 TSH 量に一定の変動を見出すととが出来なか つた．TSH 量は処置前後の甲状腺の状態に関係すると考元られるが，このことに就いては既に述べた通り である。

甲状腺末の血清 TSH 量に与える影響に就いては（表 2 ）の如く諸家の報告では全般に低下が認められる が，逆に上昇を認めて報告むある．著者も1例に增加を見たが，本症例が甲状腺ホルモン投与によつてその 低下せる下垂体活性が昂められ，TSH 分泌克進を来したと解していいかどうかは，実験成績の項に於いて 述べた如く不明である.

$\mathrm{T}_{3}$ 及び $\mathrm{T}_{4}$ 投与により 健常者及び単純性甲状腺腫の症例に血清 TSH 量の有意の低下を認め, 甲状腺 機能光進症の例に有意の低下を認めなかつたととは, Werner ${ }^{77)}$ の指摘する甲状腺機能克進症に於ける本質的 異常を下垂体に結び付けるあの之考えられるが，更に例数を重ねて確かめる必要がある.

TSH 負荷後血中 TSH 量の変動に就いては, Kassenaar ${ }^{102)}$ は白鼠は TSH 3mg USP 単位を静注して 5 分後その $50 \%$ が血中に残存すると述へ，Levey ${ }^{103}$ は同じく 2 ～ 6 USP 単位を静注後 1 時間でその $98 \%$ が流 血中から消失すると云い，D’Angelo ${ }^{\left.10^{4}\right)}$ は 6 分で30\%，30分で2.5〜6.0\%，1 時間で2.3\%，3時間で0.8\%に 減少すると云い, 鎮目等 ${ }^{105}$ は は USP 単位静注 5 分後血清 TSH 量は $3 \mathrm{~m}$ USP 単位であつたと報告, 脇坂 等 ${ }^{233}$ は甲状腺機能低下症の 1 例に $500 \mathrm{JS}$ 単位を筋注して 30 分後血液 $1 \mathrm{ml}$ に $16.9 \mathrm{~m}$ JS 単位を検出し, 正 常人では 2 時間以内に於いても有意の増加を認めなかつた。著者は筋肉内注射により Basedow 氏病に於い て血中よりの TSH 消失が幾分早い傾向を認めた。しかしての様は負荷前值に対するパーセントで表現する 方法に考慮の余地があることは既に指摘したが，Rawson ${ }^{76)}$ の TSH 不活性化説を実証するには，整密な力法 
で検討する必要がある。或は $\mathrm{S}^{35}$-TSH 等を使用するのも一つの便法であろうが，同時に in vitro に於い て直接不活性化を測定するととあ要件である.

茲で指摘せねばならないととは，甲状腺機能充進症には下垂体の異常を必要としないとする説に対する積 極的な反証を著者は得なかつたととである，著者の対象とした73例に於いては，眼突の有無に拘わらず血清 TSH 異常低值例屯高值例とほぼ同様浔められ又その低值群に TSH が関与しないととを支持する根拠む 著者の実駼結果には見当らない. 脇坂の述べる如く甲状腺機能㐫進症を一元的に統一解釈しようとするとて らに矛盾があるかも知れない。

下垂体機能低下症に於いて血中の TSH 量が低下しているととは想像に難くない（表 2 ）。小倉等 ${ }^{24)}$ は尿 崩症に異常低值を認め, 頭蓋咽頭腫の例には高值を認めたという.

肥胖女性に就いては島貫 ${ }^{28}$ は TSH 高值を, 河野等 ${ }^{25}$ はほぼ正常值を得ている.

早熟症その他臨床上稀に見る症例に関しては，TSH 測定の前例むなく, 疾病そのものについてす不明な 点が多いので, 更に例数を重文る機会を得てから改めて考察したい.

胃癌その他の慢性消耗性疾患に就いては Bakke et $\mathrm{al}^{59}$. あそれ等の下垂体の TSH 含有量の少ないとと を見出し，てれは放出充進による結果でなくて産生減衰によるすのとしている.

Addison 氏病に就いて, 小倉等 ${ }^{24)}$ は TSH 高值を報告している。本疾患に於ける BMR, PBI, I ${ }^{131}$ 摂取 率等甲状腺機能はすべてやや低值を示すとされている (Hill et al ${ }^{106)}$.) が，著者の 6 例も甲状腺機能は平均 正常の低目にあり，而してその血清 TSH 值は正常又は正常以下であつた。 著者が血清 TSH 量に若干低 值を見出した Cushing 症候群のうち 1 例は小倉等 ${ }^{24)}$ が 1 年前に測定して $0.05 \mathrm{~m} \mathrm{JSu} / \mathrm{ml}$ の異常低值を認 めたものである.

消化性潰煌の成因には ACTH の役割が重視されているが，著者が同症 6 例にやや低い血清 TSH 值を 得たととは Selye ${ }^{107)}$ の云う shift change の一端を示すあのであろうか?

自律神経症及び更年期障碍の婦人について，島貫 ${ }^{28}$ は血中 TSH 高値を認めたが，著者の対象とした神経 性食思不振症, 腸運動機能失調の症例は多少共自律神経不安定症状を示すむのであり, 而してその血清 TS $\mathrm{H}$ 量は正常或は正常以下であつた。神経性食思不振症では性腺刺㦸ホルモン分泌低下による gonadal failure が唯一の内分泌障碍と考えられるという意見 (Bliss et al ${ }^{1099}$.) があるが, 著者がこれ等に血清 TSH 量 の軽度低下を認めたととよりすれば，それが原因であるかどうかは別として，矢張り下垂体の汎機能低下が 潜在するものと推測される。

大腸運動機能失調症に於いては幾分 TSH 高值が認められたが，とれ等の有する自律神経不安状熊と血清 TSH 量との間に一定の関係は認められなかつた。著者は又これ等の患者のうち軽症例の尿中排泄遊離 17-hydroxycorticosteroids (17-OHCS) と，その血清 TSH 量との間に逆相関の傾向を見出した。最近 Kowalewski ${ }^{50)}$ は Thiouracil 投与海犋に 17-OHCS 量の低值を認めたが，AGTH 試験では対照との間に差異を認 めなかつたという，彼に従うならば，乙の場合の血中 TSH 量の上昇は甲状腺を介した 2 次的の結果に過ざ ないと屯考えられる。対象を異にするが，脇坂 ${ }^{35}$ は甲状腺機能六進症に於いて血清 PBI と尿中 17-OHCS との相関を検し，その下降型群と上昇型群とで相関の異なるととを認めている. 著者の対象とした症例に幾 分か内分泌 (副腎皮質) 機能の異常（低下）のあるととは三宅99，三好等 ${ }^{108}$ が既亿報告しているが，下垂 体甲状腺系と下垂体副婜系との関連の一面を示す資料と云える。

著者は又とれ等の裡の軽症例をえらんで AGTH 及び副腎皮質ホルモンを投与し，前者では一定の傾向 を認めなかつたが，TSH 上昇作用がある如き結果を得た。 ACTH及び副㹂皮質ホルモンが下垂体甲状腺系 に及ぼす影響に就いて多数の報告があり，2３の綜説 ${ }^{110-112)}$ にあ明らかにされている如く報告者によつて 実験条件を異にするためか全く相容え好意見が多いが，ACTH 及び副婜皮質ホルモンが結果として甲状腺 機能を低下せしめるという説が多い上うである。乙の場合の作用機序に就いては，i）下垂体前葉のTSH 分 泌を抑制するという説 ii）直接甲状腺機能を抑制すると云う説 iii）TSH の作用を抑制するとする説 iv）婜に於けるヨード clearance を高める結果とする説，その他最近 v) 末梢に於いて thyroxine を抑制 
し，その triiodothyronine への degradation を抑制するとする説15゙ があるがこれらの説に対する反証む 枚挙に睱がない程である。しかし最近 Beck ${ }^{113)}$, Dyrenfurth et $\mathrm{al}^{114)}$. は cortisone, ACTH 投与により TSH の産生放出分昂められると云い，小倉等 ${ }^{116) 117)}$ は ACTH， cortisone によつて二次的に血清 TSH 量の上 昇するととを推定し, 実験的には ACTH による血中 TSH 量の下降, cortisone による TSH 量の增高を 認めている。越智多 無機 $\mathrm{I}^{131}$ 放出に於いて cortisone が TSH とは反対の作用を示すととを認めたが，一方 Bakke et al ${ }^{599}$ は prednisone 長期投与患者の下垂体 TSH 含量が極めて低值であつたととを認め，皮質ステロイドの下垂体 抑制作用を考えている。しかし著者等 ${ }^{118)}$ も副掔皮質ホルモン長期投与によつて発症したと考劣られる粘液 水腫を経験したが，乙の症例は発症後さ程長期間を経過しておらず，その血清 TSH 量は異常高値を示さな かつたが，TSH 試験では陰性で原発性甲状腺機能低下症之診断された。

著者は尿崩症の 1 例に vasopressin を投与して血中 TSH 量の上昇を得たが，該ホルモンの甲状腺に対 する作用についても，その $\mathrm{I}^{131}$ 掑取を促進するという報告 (Froja et al ${ }^{119)}$, 'Dubreuil et al ${ }^{120)}$.) と反対に $\mathrm{I}^{131}$ 摄取を抑制するという報告 (Isler et al ${ }^{121}$.) がある. 又 Isler $^{122)}$ によれば vasopressin は腎のヨード clearance を促進するという. 最近 vasopressin は不垂体前葉をして AGTH 分泌を促進せしめる ${ }^{123-126)}$ と 云われ, Nichols et al ${ }^{127)}$ はこの説に疑問を投げているが Bottari ${ }^{45)}$ ，小倉等 ${ }^{129)}$, 及び Vecchio et al ${ }^{129}$. は varopressin による血中 TSH 量の上昇, 或は TSH 分泌增加を認めている. 下垂体後葉と甲状腺との関

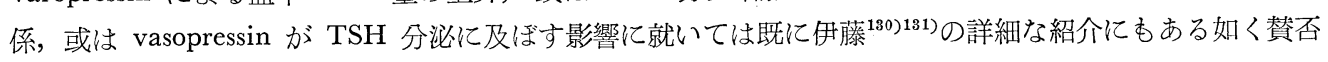
交々で, なお未解決な点が多く向後の研究に待つとてろが大きい.

以上の考按を通し，著者の得た結果が全面的に必ずしも十分の成績でなかつたととは，各測定值の Standand deviation が大きいとと，各測定值が広範囲に分散しているととに端的に表現されている。更に明 確な結論を得るために，より正確且つ鋭敏な測定法の確立へ，今一歩の努力が要請されるものと思われ る.

\section{総 括}

1）著者が一部改良した，牛甲状腺 slice に於ける無機 $I^{131}$ 放出率抑制による TSH 微量測定法を臨床 に応用するに臨み, 更に検討を加えて後, 人血清 TSH 測定を行つた。

2）正常人 41 例に於ける血清 TSH 量は平均 $1.75 \mathrm{~m} \mathrm{JSu} / \mathrm{ml}$ であり, 信頼度 0.95 に於ける信頼区間は 2.2 1.3 m JSu/ml であつた. 又男子例はやや低值を, 又高令者は低值を示し, 李節的変動を認めた。

3) 单純性甲状腺腫の裡, PAS 甲状腺腫は高值, びまん性はやや高值, 囊腫性は正常の上界, 結節性は やや低值を示し, その血清 PBI 值との間に逆相関の傾向を得た。

4）甲状腺機能低下症に於いては，原発性は明らかに異常高值を示す例が多く，下垂体性は多く異常低值 を示した.

5) 甲状腺機能穴進症73例に於いては $0.1 \mathrm{~m} \mathrm{JSu} / \mathrm{ml}$ 以下より $10 \mathrm{~m} \mathrm{JSu} / \mathrm{ml}$ 以上にわたる広範蛙分散が 認められ，その平均值は正常上界に位した。眼球突出の有無に拘わらず異常高值と異常低值がほぼ同数に見 られたが，眼突群には異常高值を示す例が若干多く， $1^{131}$ 掑取率曲線の型によつて分類すれば，眼突群に は下降型が多くその TSH 量にも高值の傾向を認めた。しかし眼突を有する甲状腺機能正常者 2 例には血 清 TSH 上昇を認めなかつた。而しててれ等の血清 TSH 量と血清 PBI, 及び血清 TSH 量と $\mathrm{I}^{131}$ 摂取率 ( 6 時間值) とは何れも有意の相関を示さなかつたが，その相関係数は後者が幾分大であつた. 又各種抗甲 状腺䯇及び I ${ }^{131}$ 療法により血清 TSH 量は増加の傾向を示した。

6) $\mathrm{T}_{3}$ 又 $\mathrm{T}_{4}$ 投与により甲状腺機能正常者の 3 例に有意の血清 TSH 量の低下を認めたが， Basedow 氏病 4 例中 2 例には明らかな TSH 值低下を認めなかつた. 又 TSH 負荷を行つて血中 TSH 量の変動を 観察した.

7）下垂体，副腎，その他の内分泌疾患及び 2,3 の他種疾患患者の血清 TSH 量を測定し，多くが正常 
下界或は異常低值にあることを認めた。

8）大腸運動機能失調症，消化性潰瘍及び神経性食思不振症の 1 群に於いては，血清 TSH 量が尿中排泄 17-OHCS と逆相関の傾向を示すととを認め, 叉 ACTH 投与時一定の傾向を示さなかつた。プレドニりロ ン投与により血清 TSH 量は増加の傾向を示した。

9）尿崩症の 1 例に vasopressin を投与し，血中 TSH 量の上昇を認めた。

10）以上の実験成績の臨床的意義に関して若干の文献的考察を行つた。

稿を終るに臨み, 終始, 御愁篤なる御指導御鞭撻芭睗わつた恩師脇坂教授に厚く御礼申し上げます。併せ て常了御助言御尽力を戴いた鳥塚博士並びに共同研究者有田学士に感謝致します。

\section{文献}

1) Hertz, S. \& Oastler, E.G. : Endocrinology, $20: 521 ， 1936$. (文献11)上り引用) 2 2) Rawson, R.W. \& Starr, P. : Arch. Int. Med., $61: 726,1938 . \quad 3)$ Jones, M.S. : Endocrinology, $24: 665$, 1939. (文 献11)上り引用） 4) Savoie, J.C. : Ann. endocrinol., 13:81，1952. (文献 8 )ょり引用)

Crook, A.C. \& Mathews, J. D. : Ciba Found. Colloq. Endocrinol., 5:25, 1953. (文献10)より引用)

6) Bloche-Michel, H. \& Henry, R. : Ann. endocrinol., $16: 268$ ，1955. (文献 8 )上り引用) 7) Kriss, J.P. \& Greenspan, F.S. : J. Clin. Endocrinol., $14: 770,1954 . \quad 8$ 8) Adam, D.D. \& Purves, H.D. : Metabolism, 6:26, 1957.

No. 1, 1956. (交献 8 ) 上り引用)

9) Adams, D.D \& Purves, H.D. : Proc. Univ. Otago med. Sch., 34 : 查法」, 33, 1956 .

10）西川光夫：内分泌のつぞい委員会編「最も新しいホルモン検

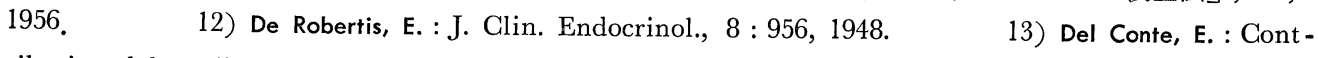

11）柴田勝博：内分泌のつぞい委員会編「最も新しいホルモン検査法」，37, ribution del coefficiente citologico a la fisiologia $\cdot y$ patologia de la correlation hipofisotiroidea." Edit. el. Atenes. Buenos Aires, 1949. (柴田勝博，ホルモン之臨床，4:949,1956. 上り引用) 14) Purves, H.D. \& Griesbach, W.E. : Brit. J. Exper. Path., $30: 23,1949$.

15) D’Angelo, S.A., Paschkis, K.E., Gordon, A.S. \& Cantarow, A. : J. Clin. Endocrinol., $11: 1237,1951$.

16) Simkin, B., Starr, P. \& Hancock, C. : Endocrinology, $48: 940,1952 . \quad 17)$ DiGeorge, A.M., D’Angelo, S.A. \& Paschkis, K.E. : J. Clin. Endocrinol., $15: 834,1955$.

18) DiGeorge, A.M., D'Angelo, S.A. \& Paschkis, K.E. : J. Clin. Endocrinol., $17: 842,1957$.

19) Gilliland, I.C. \& Strudwick, J.I. : Brit. Med. J., $1: 378,1956$.

20) Adams, D.D. : J. Clin. Endocrinol. \& Metab., $18: 699$, 1958.

21) McKenzie, J.M. : Endocrinology, $63: 372,1958$.

22) Bottari, P.M. : J. Endocrinology, 17 : xix, 1958.

23) 脇坂行一,

河野 剛, 山田光雄, 伊藤憲一, 小林 功, 鳥塚莞爾, 西河 直, 平井拓造, 小野村誠弥, 兽我美勝: 最新 医学, $13: 1588$, 炤33.

24）小倉 一, 佐古田雅弘：日内分泌会誌，34:274, 昭33.

河野 剛, 鳥塚莞爾, 平井拓造, 小林 功, 吉川守之, 小野村誠弥, 坂元良実, 日下部恒輔：ホルモンと蹦 床, 近刊. 26) 野口秋人, 山崎鋭一, 佐藤誠也, 福島郁子 : 日内分泌会誌, $35: 219$, 昭 34 .

27）入江 実, 鎮目和夫, 石井 淳, 松田邦夫, 長滝重信 : 日内分泌会誌, $35: 220$, 昭 34 . 島貫太吉：ホルモンと臨床，6:1030，䀡33. 29$)$ Fellinger, K. : Wien. Arch. inn. Med., $29: 375$, 1936. 30) Collard, H.B., Mills, F.H., Rundle, F.F. \& Sharpey-Schafer, E.P. : Clin. Sc., $4: 323,1940$.

31) Albert, A. : Ann. New York Acad. Sc., $50: 466,1949$.

32）置塩郁三, 井上 康, 植田安雄 :

日内分泌会誌, $33: 126$, 炤 32 .

33）永田 格: 未発表, 日内分泌会誌近刊.

34) Gaddum,

J.H. : J. Pharm. \& Pharmacol., $6: 345,1953 . \quad 35)$ 脇坂行一：日内会誌， $46: 1262$, 昭 33.

36) Bakke, J.L., Heideman, M.L., Lawrence, N.L. \& Wiberg, C. : Endocrinol., 61 : 352, 1957.

Florsheim, W.H., Moskowitz, N., Schwartz, J.R. \& Morton, M.E. : Endocrinol., 60 : 683, 1957.

越智幸男 : 未発表。

39) Van Wagenen, G. \& Simpson, M.E. : Proc. Soc. Exper. Biol· \& Med., 90 : 
$346,1955$.

40）赤須文男，河原 節，原野道子，大木 博，手島洋子：日内分泌会誌，32：(2) 112, 昭31. 41）東条伸平，森下和彦，矢野一哉：日内分泌会誌，35:225，昭 34 .

42) Cohn,

E.J. : Am. Scient., $33: 61 ， 1945$.（文献21)より引用）

Roy. Soc. Med., 49 : 209, 1956 (文献21)より引用)
43) Querido, A. \& Lameijer, L.D.F. : Proc.

44) Postel, S. : Endocrinol., $58: 557,1956$.

45) Bottari, P.M. : Ciba Found. Cell. on Endocrinol., $11: 52,1957.46$ 小倉 一：第32回日本内 分泌学会総会, 䀡 34 .

47) Bakke, J.L. \& Lawrence, N. : Endocrinol., $58: 531,1956$.

Adams, D.D. \& Purves, H.D. : Endocrinol., 57 : 17, 1955

N.L. : J. Glin. Endocrinol. \& Metab., $19: 831,1959$.
49) Heideman, M.L., Bakke, J.L. \& Lawrence,

50) Kowalewski, \{K. : Acta endocrinol., 27, 257, $1958 . \quad$ 51) Starr, P., Lepp, A. \& Katz, Y.: J. Clin. Endocrinol. \& Metab., 18 : 278, 1958. 52) 小倉 一, 辻 昇三: 日内分泌会誌, $33: 118$, 昭 32 . 53) Greer, M.A. \& Shull, H.F. : J. Glin. Endocrinol. \& Metab., 17 : 1030, 1957. 54) 吉川守之：内科宝函，6:408, 昭34. 55) 渡

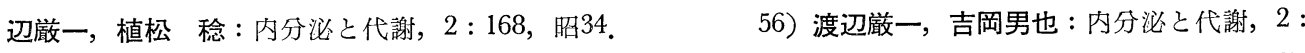
163, 昭34. : in Werner, S.C. : The Thyroid, Hoeber-Harper, New York. 341, 1957. 63) Greer, M.A. : J. Clin. Endocrinol., $12: 1259,1952$.

64) Greer, M.A : Endocrinology, $64: 724,1959$.

Florsheim, W.H. : Endocrinology, 62 : 783. 1957.

66) Bottari, P.M. \& Donovan, B.T. : J. Physiol., 140 : 36, 1958.

67) Asboe-Hansen, G., Iversen, K. \& Wichmann, R. : Acta endocrinol., $11: 376,1952$.

68) Dobyns, B.M. \& Steelman, S.L. : Endocrinology, $52: 705,1953$.

69) Jefferies, W. McK. : J. Clin. Endocrinol., 9 : 927, 1949.

70) Lamberg, B.-A. : Acta Med. Scandinav., $156: 361,1957$.

71) Lamberg, B.-A. : ibid., $156: 377,1957$.

72) Lamberg, B.-A. : ibid., $156: 391,1957$.

Silverstini. F. \& Pasargiklian, E. : Lés oftalmo endocrino, Livorno., 1955 (文献71)より引用)

Friis, T. \& Chapman, E.M. : Acta endocrinol., 27 : 207, 1958.

75) McKenzie, J.M. : Endocrinol., 62 : $865,1958$.

1957. 76) Rawson, R.W. : in Werner, S.C. The Thyroid, Hoeber-Harper, New York. 441, on, D.E., Solomon, D.H. \& Greer, M.A. : J. Clin. Endocrinol. \& Metab., 19 : 317, 1959.

78) Johnslin, C. : Ann. d'anat. path., $15:$ 703，1938. (文献77)より引用)

80) Werner, S.C. \& Stewart, W.B. : J. Clin. Endocrinol. \& Metab., 18 : 266, 1958. 81) Albeaux-Ferne, M., Guiot, J., Brawn, S. \& Romani, J.D. : J. Clin. Endocrinol. \& Metab., 15 : 1239, 1955. 82) McCullagh, E.P., Clamen, M. and Gardner, W.J. : J. Glin. Enlocrinol. \& Metab., 17 : 1277, 1957. Radley Smith, E.J. : J. Clin. Endocrinol. \& Metab., 19 : 717, 1959. 83) Gucling, K.J., Baron, D.N. \& 84) Becker, D.V. : J. Clin. En docrinol. \& Metab., 19 : 840, 1959.

1958. 86) 有田 隆: 未発表.

85) Fajans, S.S. : J. Glin. Endocrinol. \& Metab., $18: 271$, 88）朝長富夫：日内分泌会誌，34：1332，昭34. 89) 三宅 儀：第15回日本医学会総会口演，昭34 年. 90) 三宅 儀：日内分泌会誌，34:514，昭33. 91）飯田 太，佐野悦司，降旗力男： 日内分泌会誌，34:1260。昭34. 92) 前沢 潭: 信州医学誌, $7: 722$, 昭33. 93) 志田 寛 前沢 潭, 千島洋秀: 日内分泌会誌, $35: 218$, 昭 34 . 94) Fraser, T.R., Garrod, O.G., Hanno, M.G. W. \& Jadresic, A. : J. Clin. Endocrinol., 14 : 1230, 1954.

95) 佐野 進, 近衞晃賢, 渡辺 薰: 日 内分泌会誌，35:214，昭34. 96) 島 隆允，村上寅雄，山本 泰：日内分泌会誌，34:1331，昭 34. 97) Albert, A. \& Rawson, R.W.: J. Biol. Chem., $166: 637,1946 . \quad 98)$ Del Conte, E. \& Stux, M. : Rev. Soc. Argentina Biol., $30:$ 175, 1954. (Medical abstract 1957.より引用)

99) Greer, 
M.A. \& DeGroot, L.J. : Metabolism, 5 : 682, 1956.

Clin. Endocrinol. \& Metab., 18 : 367, 1958.
100) Goldsmith, R., Herbert, C. \& Lutsch, G. : J. 101) Benua, R.S. \& Lipsett, M.B. : J. Clin. Endocrinol. \& Metab., 19 : 19, $1959 . \quad$ 102) Kassenaar, A.A.H., Lameyer, L.D.F. \& Querido, A. : Acta endocri nol., $21: 32,1956 . \quad$ 103) Levey, H.A. \& Solomon, D,H.: Endocrinol., $60: 118,1957 . \quad$ 104) D' Angelo, S.A. : Endocrinol., $56: 1,1955.1105)$ 鎮目和夫, 入江 実, 飯野史郎 : 最新医学, $12: 23$. 昭32. 106) Hill, S.R. Jr., Reiss, R.S., Forsham, P.H. and Thorn, G.W. : J. Clin. Endocrinol., $10: 1375$, 1950. 107) Selye, H. : Text book of Endocrinology, Acta Endocrinol., Montreal, Canada 226, 84 5，1949（文献 110）より引用） 108）三好秋馬, 岡島 喬, 上野昌律, 有田 隆, 宮崎重武. 永田 格，久保勝彦：日内分泌会誌，34：1321，眧34. 109) Bliss, E.L. \& Migeon，C.J. : J. Clin. Endocri nol. \& Metab., $17: 766,1957 . \quad 110)$ 山本 清: 内分泌機能の協関, 甲状腺叢書第 1 輯, 22 , 炤 31 . 111) Money, W.L. \& Lerman, J. : in Werner, S.C. The Thyroid 2nd edition Hoeber-Harper, New York, P.83，595. 1957. 112）野口秋人：甲状腺の臨床，甲状腺叢書第 2 輯，169，昭32。1113) Beck，R. N. : Endocrinology, $62: 9,1958 . \quad$ 114) Dyrenfurth, I., Sybulski, S., Notcher, V., Beck, J.C. \& Venning, E.H. : J. Clin. Endocrinol. \& Metab., $18: 391,1958 . \quad 115)$ Bastenie, P.A. and Ermans, A.M. : End ocrinol., $62: 245,1958$.

116) 佐古田雅弘, 小倉 一, 前田浩之：日内分泌会誌，34:1327, 昭34. 117) 辻 昇三, 佐古田雅弘, 前田弘之, 小倉 一 : 日内分泌会誌, $35: 226$, 昭34. 118) 池本信義, 有田 隆, 永田 格, 久保勝彦, 波多野元久, 坂本克已, 大江慶治, 西祥太郎：内科宝函, $6: 801$, 昭 34 . 119) Froja, A. \& Martini, L. : Arch. int. Pharmacodyn., 93 : 167，1953.（文献45）ょり引用） Dubreuil, R. \& Martini, L. : XXth Int. Physiol. Congr., P. 257，1956.（文献45）ょり引用) Isler, H., Brunswick, J.P., Fish, C.R., McClean, J.S.M. \& Schwenk, A.C. : Mc Cill Med. J., 20 : 151, 1957. (Medical abstract より引用) 122) Isler, H. : Endocrinol., 64 : 807, 1959. 123) Mirsky, I.A., Stein, M. \& Paulisch, G. : Endocrinol., $55: 28,1954$. 124) McDonald, R.K., Weise, V.K. \& Patr ick, R.W. : Proc. Soc. Exper. Biol. Med., 93 : 348, 1956. 125) McCann, S.M. : Endocrinol., $60: 664$, 1957. 126) Martini, L., DeRoli, A. \& Curri, S. : Proc. Soc. Exper. Biol. Med., 91 : 490, 1956.

127) Nichols, B. \& Guillemin, R. : Endocrinol., 64 : 914, 1959. 128) 辻 昇三, 前田浩之, 佐古田雅 弘, 小倉 一：日内分泌会誌，35:227, 昭34.

129) Vecchio, A.D., Genovese, E. \& Martini, L. : Proc. Soc. Exper. Biol. Med., 98 : 641, 1958. 130) 伊藤真次 : 最新医学, $12: 1443$, 昭 32 . 131) 伊藤真次 : 最新医学, $13: 1652$, 昭 33 . 132) Greenspan, F.S. and Lew, W. : Endocrinol., 64 : 160, $1959 . \quad$ 133) Austin, F.K., Rubini, M.E., Meroney, W.H. \& Wolff, J. : J. “ Glin. Invest., 37 : $1131,1958$. 